$$
L A-54 B-96-62
$$

\title{
UWC Geothermal Resource Exploration
}

\section{DISCLAIMER}

This report was prepared as an account of work sponsored by an agency of the United States Government. Neither the United States Government nor any agency thereof, nor any of their employees, makes any warranty, express or implied, or assumes any legal liability or responsibility for the accuracy, completeness, or usefulness of any information, apparatus, product, or process disclosed, or represents that its use would not infringe privately owned rights. Reference herein to any specific commercial product, process, or service by trade name, trademark, manufacturer, or otherwise does not necessarily constitute or imply its endorsement, recommendation, or favoring by the United States Government or any agency thereof. The views and opinions of authors expressed herein do not necessarily state or reflect those of the United States Government or any agency thereof.

\section{MASTER}




\section{DISCLAMMER}

Portions of this document may be illegible in electronic image products. Images are produced from the best available original document. 


\section{Table of Contents}

Abstract $\ldots \ldots \ldots \ldots \ldots \ldots \ldots \ldots \ldots \ldots \ldots \ldots \ldots \ldots$

Project Overview. ........................

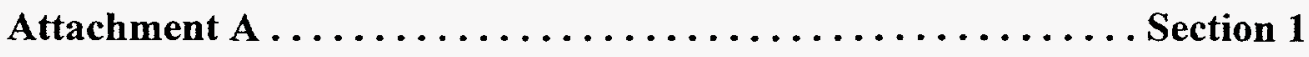

Attachment B $\ldots \ldots \ldots \ldots \ldots \ldots \ldots \ldots \ldots \ldots$ Section 2

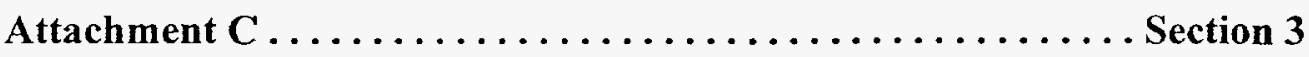

Attachment $D \ldots \ldots \ldots \ldots \ldots \ldots \ldots \ldots$ Section 4

Attachment $\mathrm{E} \ldots \ldots \ldots \ldots \ldots \ldots \ldots \ldots \ldots \ldots \ldots$ Section 5

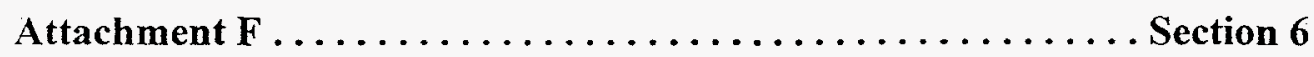




\section{ABSTRACT}

A consortium was formed with Los Alamos National Laboratory (LANL), Sandia National Laboratory (SNL), and New Mexico State University (NMSU). Funding support was received from the U.S. Department of Energy (U.S. DOE) and the State of New Mexico. A program was developed to explore the strength of the geothermal and hot dry rock (HDR) resource at the Montezuma Hot Springs at the United World College (UWC). The purpose of the UWC \#1 well is to obtain hydrologic, geologic, and temperature information for ongoing geothermal evaluation of the Montezuma Hot Springs area. If sufficient fluids are encountered, the hole will be cased with a $41 / 2$ inch production casing and re-permitted as a geothermal low-temperature well. If no fluid is encountered, the well will be abandoned per Oil Conservation Division regulation. The objectives of the exploration are to evaluate the resource potential to provide space heating for the entire campus of the United World College, determine the effect of a well on the Hot Springs outflow, accurately measure the UWC heating loads versus time, evaluate the potential to support local thermal industry development, assess the feasibility of HDR development, and create an educational program from the collection of data derived from the research effort. 


\section{PROJECT OVERVIEW}

This report is being presented in January 1996, to correspond to the requirements of subcontract \#6849V0015-3G. As of this date, drilling of the exploratory well is scheduled for the end of February 1996, which is in about four weeks. The accomplishments to date consist of instrumentation installed to accurately measure UWC heating loads. These measurements included heating loop supply and return water temperature, heating loop flow rate, input and output main water circulation pump pressure, power consumption of the main and re-circulation pumps, ambient air temperature inside and outside the beating plant, and outdoor wind speed and direction. See report entitled, "UWC Geothermal Resource Exploration," submitted as Attachment A. Additional instrumentation was installed in the Hot Springs to measure spring flow rate, spring water temperature, and to collect data over a longer period of time, submitted as Attachment $B$.

Location and survey of UWC Well \#1 have been completed by project geologists from NMSU and LANL. Several surveys were conducted and errors were corrected on local maps.

The project team has met with local drilling contractors to discuss type of equipment needed for the project. The safety aspect of the equipment is of primary concern due to the many unknowns of the project. For example, Blow Off Protection Equipment (BOPE) is required for protection from high pressure pockets. Decisions have been made to bring instrumentation to the drilling site in the form of well logging tools and instrumentation trailers from Sandia. Measurements will be made for temperature, flow rate, gamma radiation and chemical composition.

Considerations are being given to harness the natural power beneath the springs to replace the existing coal-burning heating plant, depending upon the geothermal strength.

Upon completion of the exploratory well and analysis of the data, decisions will be made to select the most viable option. See report entitled, "United World College Geothermal Space Heating Project Overview," submitted as Attachment C.

Collaborative efforts are continuing with LANL to establish an educational resource center at the hot springs on geothermal energy. The development of educational materials and programs would be based on the information gathered during the course of evaluating the geothermal potential of the springs. 
Information collected by researchers at the UWC about the hot springs is provided as Attachment $D$, an extension of an earlier report submitted a year ago. This information provides a rich mine of material, which can be used for science lessons and laboratory projects at the senior high school or university level. Materials already written for both students and teachers are included as Attachments $E$ and F.

At the Armand Hammer United World College, students study for the diploma of the International Baccalaureate, a two-year curriculum in which every candidate must take at least one course in science. Changes in the structure of the science curriculum to be implemented from August 1996, require that each student participates in a project with students from other science courses. Faculty members of the science department at UWC have decided that these science group projects should use the hot springs as the focus of study and investigation. These efforts will involve over one hundred students and six members of the faculty each year and will provide a great deal of impetus and effort towards developing new educational ideas and materials. 
ATTACHMENT A

The Hot Springs

at

Montezuma, New Mexico

UWC Geothermal Resource Exploration

Sandia National Laboratories Report

Section 1 


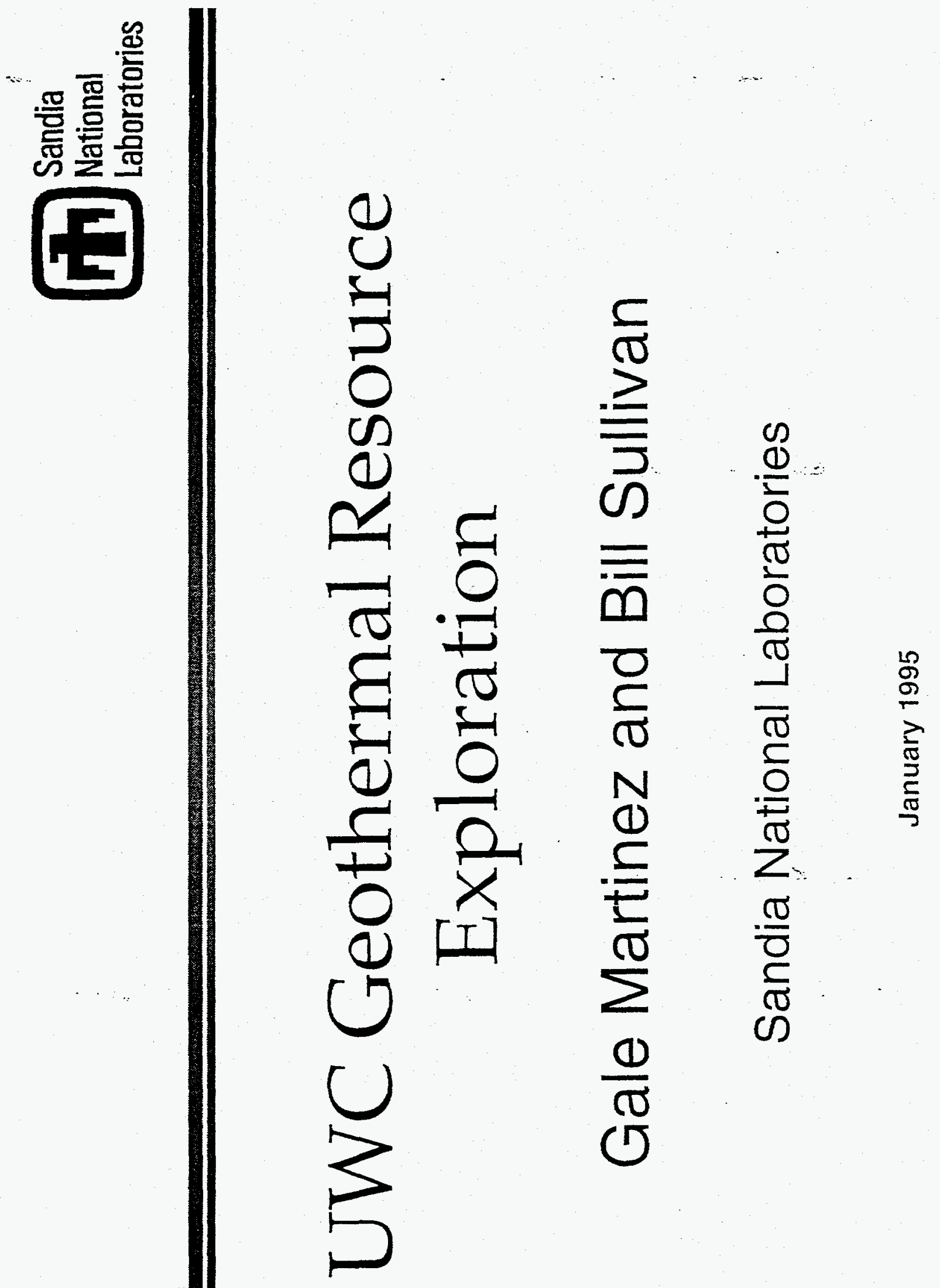




\section{Project History \\ 闻部的

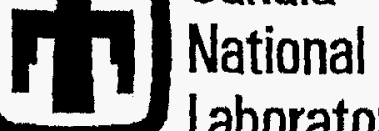 Laboratories}

1992 UWC President, Ted Lockwood; asks LANL to examine using geothermal hot springs to replace coal-fired boiler.

1993-1994 Mark Nickerson (LANL) drafted report on geological characteristics of area and possibility of using the geothermal resource for heating. SNL participated by supplying data on heat pumps for augmenting geothermal sources.

March 1994 LANL/SNL met with new UWC President, Phil Geier, to discuss heating options for facilities. All options required further knowledge of the resource which can only be determined by exploratory drilling.

Summer 1994 NMSU (SWTDI) asked to participate because of their knowledge of New Mexico resources and experience in direct geothermal heating systems. Joint proposal written by SNL, UWC, LANL, and NMSU to request funding of $\$ 200 \mathrm{~K}$ for exploratory drilling.

Fall 1994 Submitted Proposal for "State Match for Technology-Based Proposals" Program. Requested \$45K of state funds and $\$ 55 \mathrm{~K}$ of DOE funds to develop a shallow, low cost, exploratory well and explore broader economic development options for the region.

Winter

1994-19.95

DOE/GD and State match funds awarded.

Present Monitoring UWC heating load and weather data. Beginning geological survey to determine best site for exploratory well. 


\section{Why Support this Project?}

- UWC is a Valuable Cultural, Educational, and Economic Resource for the State of New Mexico and the Economically Depressed Las Vegas Region which may Benefit from Laboratory-Sponsored Technology Transfer.

- Great Opportunity to Support Displacement of a Coal-Fired System with DOE-Sponsored Renewable Energy Technology.

- Can be a Highly Visible and Effective Demonstration of

Federal/State/Public/Private Partnerships. 


\section{Initial Project Goals

- Utilize the Montezuma Hot Springs to:

- Heat the College Facilities

- Promote Environmental Awareness

- Educate the Students and Local Community

- Initial Funding by DOE $(\$ 55 \mathrm{~K})$ and the State of NM (\$45K) will Provide Shallow Exploratory Well(s) for Resource Evaluation and Detailed Measurements of UWC Heating Loads. 


\section{Future Goals}

If the Resource is Substantial, Additional Goals are Possible:

- Broaden UWC's Environmental Studies Program

- Develop a Renewable Energy Educational Center in Northern NM

- 'Adaptive Reuse' of the Montezuma Castle

- Generate electricity using HDR Technology

- Local Economic Development Opportunities:

- Well Drilling Industry

- Greenhouse Horticulture

- Aquaculture

- Apple Dehydration

- Tourism

Funding Sources for these Broader Goals is TBD! 


\section{UWC Heating System}

- Boiler Heating System for Space Heating \& Hot Water Heating

- $121,000 \mathrm{ft}^{2}$ of facilities

- Coal Boiler Consumes 600 Tons per Year

* Annual Coal Costs: $\$ 35,000, \$ 6500$ for Maintenance

* Annual Electricity Costs: $\$ 126,000, \$ 10,000$ for Maintenance

- Future Expansion of Heating System Proposed

* $25,800 \mathrm{ft}^{2}$ of Additional Residences Currently Heated by Propane or Electricity

* Montezuma Castle

- Heated Water Circulated through Radiators and Fan Coil Units in Individual Rooms of Buildings

- $T_{\text {supply }}=178^{\circ} \mathrm{F}, T_{\text {return }}=175^{\circ} \mathrm{F}$

- Flow Rate $=1150$ GPM During the Heating Load, 700 GPM in Summer. 


\section{UWC Heating System Schematic}

- High Temperature $\left(180^{\circ} \mathrm{F}\right)$ Water Loop

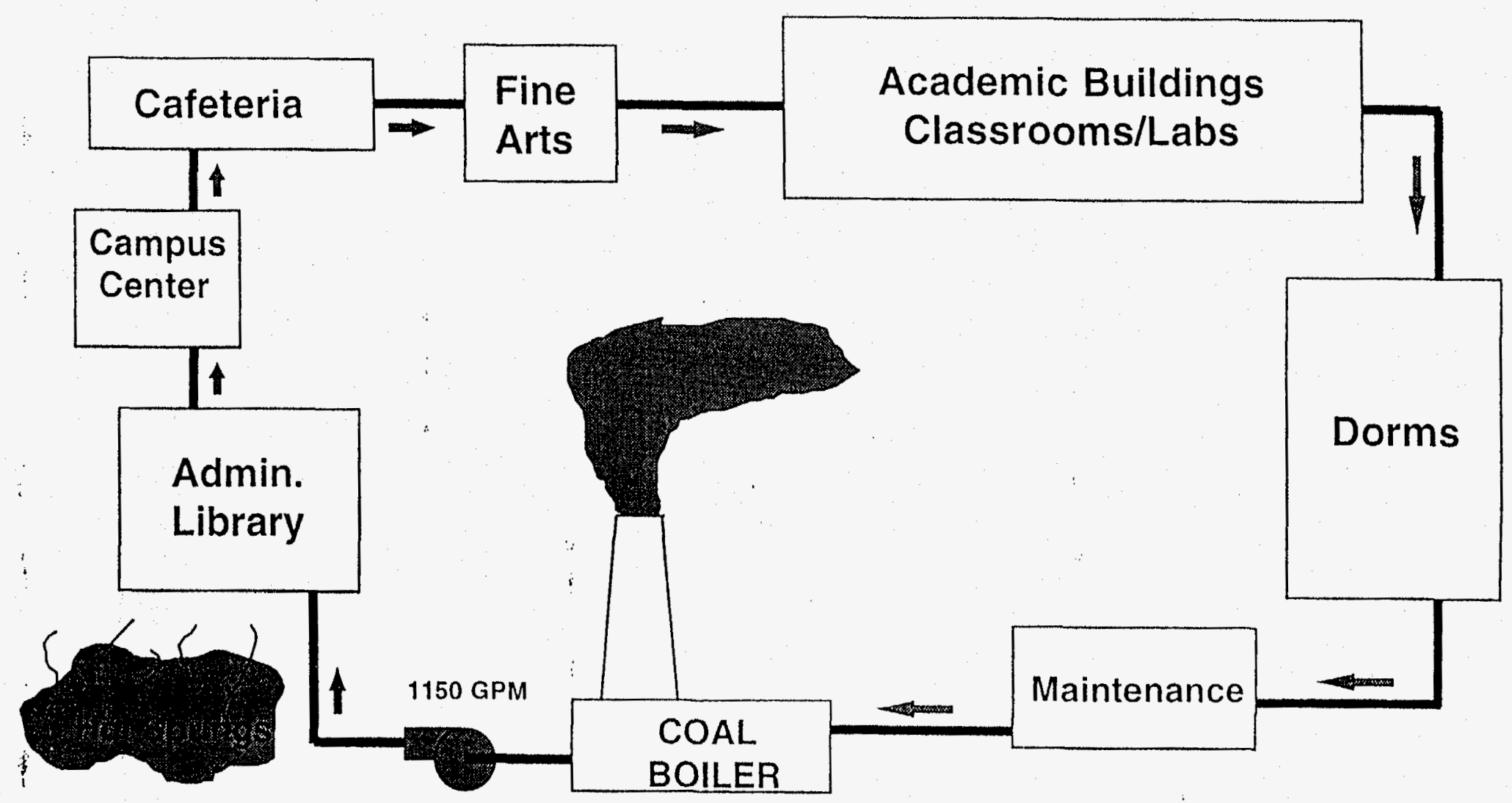




\section{Geothermal Space Heating Options}

\section{Choice of Heating Options Depends on Resource Strength}

Option 1: Direct Geothermal Heating

Lowest Cost Option if the Resource Temperature $>150^{\circ} \mathrm{F}$, High Flow Rate.

Option 2: Geothermal Heating Augmented with Heat Pumps

Necessary if Resource Temperature $<150^{\circ}$ F, Flow Rate $<200$ GPM.

Option 3: Geothermal Heating Augmented with HDR

HDR Used to Boost Flow if Resource Flow Rate Weak.

Option 4: Geothermal Heating Using HDR

Development of HDR Geothermal Energy System if High Temperature Gradient Exists. 


\section{Geothermal Exploration Project}

\section{Phase I Objectives}

- Explore the Strength of the Geothermal Resource at UWC.

- Evaluate the Resource Potential to Provide Space Heating for UWC.

- Determine the Effect of a Well on the Hot Spring Outflow.

- Accurately measure the UWC Heating Loads.

- Evaluate the Potential to Support Local Thermal Industry Development.

- Assess the Feasibility of HDR Development. 


\section{Geothermal Exploration Project Plan}

\section{PHASE I TASKS}

- Complete Geological Survey of the Hot Springs Area.

- Determine Best Exploratory Drilling Site(s).

- Drill Test Well(s).

- Acquire Well Logging Data.

- Measure Heating Demand of UWC Facility.

- Analyze Test Data.

- Recommend Best Heating Option and Propose Future Studies for Phase II. 


\section{Roles of Partners in Exploration Project}

\begin{tabular}{|c|c|c|c|c|c|c|c|}
\hline $\begin{array}{c}\text { Partner/ } \\
\text { Tasks }\end{array}$ & $\begin{array}{c}\text { Geological } \\
\text { Survey }\end{array}$ & $\begin{array}{l}\text { Pick Drill } \\
\text { Site }\end{array}$ & $\begin{array}{l}\text { Contract } \\
\text { Drilling }\end{array}$ & $\begin{array}{c}\text { Well } \\
\text { Logging }\end{array}$ & $\begin{array}{l}\text { Measure } \\
\text { Heating } \\
\text { Demand }\end{array}$ & $\begin{array}{c}\text { Data } \\
\text { Analysis }\end{array}$ & Funding \\
\hline UWC & $X$ & $X$ & $X$ & & & $X$ & $\begin{array}{r}\$ 25 K \\
\text { (in-kind) }\end{array}$ \\
\hline NMSU & $X$ & $X$ & $X$ & & & $X$ & $\$ 45 K$ \\
\hline LANL & $X$ & $X$ & & & & $X$ & $\$ 15 K$ \\
\hline SNL & & $X$ & & $X$ & $X$ & $X$ & $\$ 40 K$ \\
\hline
\end{tabular}




\section{UWC Heating Load Measurements}

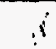

- Instrumentation Installed in October 1994.

- Measurements Include:

- Heating Loop Supply and Return Water Temperature

- Heating Loop Flow Rate

- Input and Output Main Water Circulation Pump Pressure

- Power Consumption of the Main and Recirculation Pumps

- Ambient Air Temperature Inside and Outside the Heating Plant

- Outdoor Wind Speed and Direction

- Measurement System Samples Data every 20 Seconds.

- Data is Stored every 15 Minutes.

- 15 Minute, Hourly, and Daily Averages

- Maximums, Minimums, and Totals 


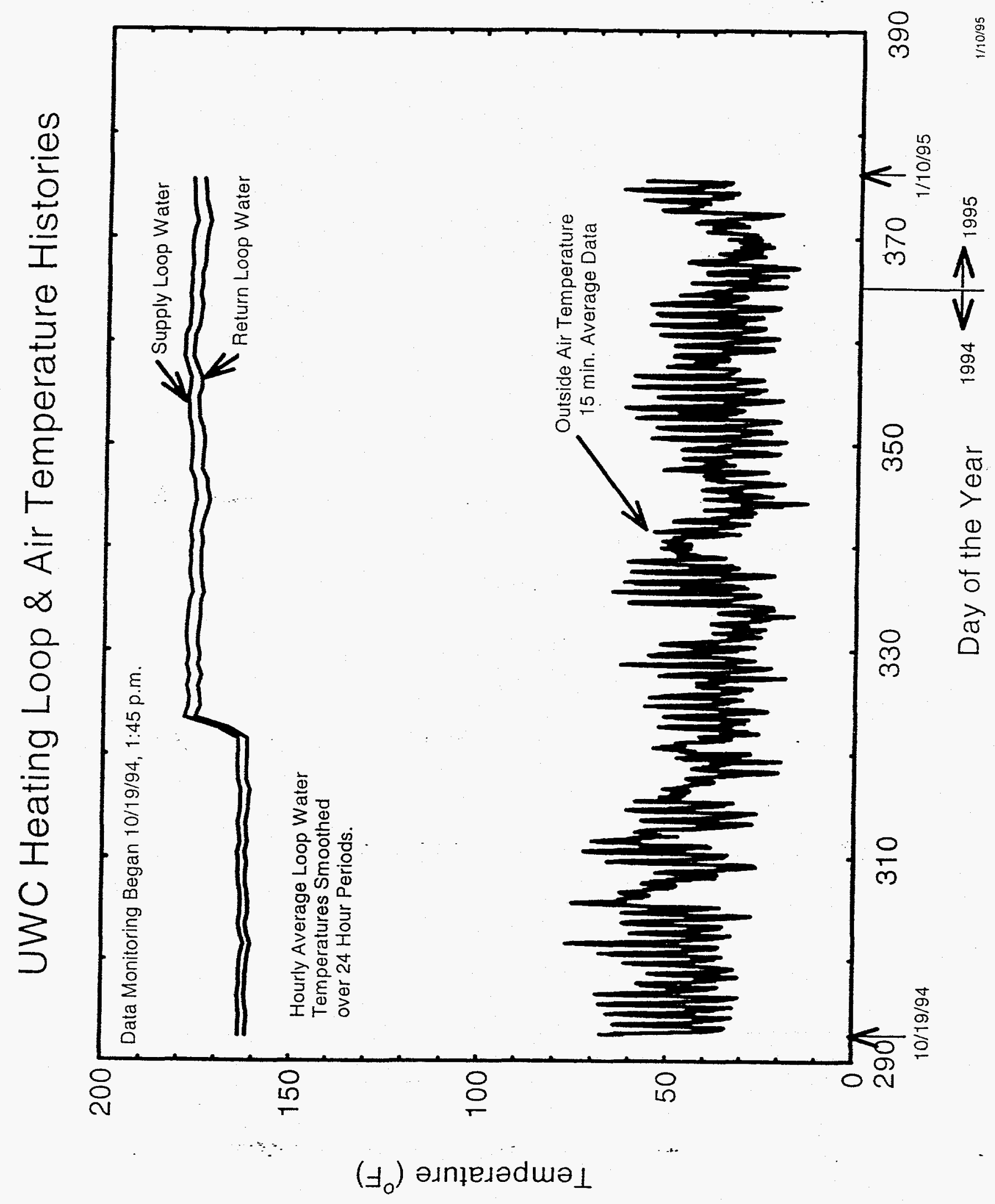




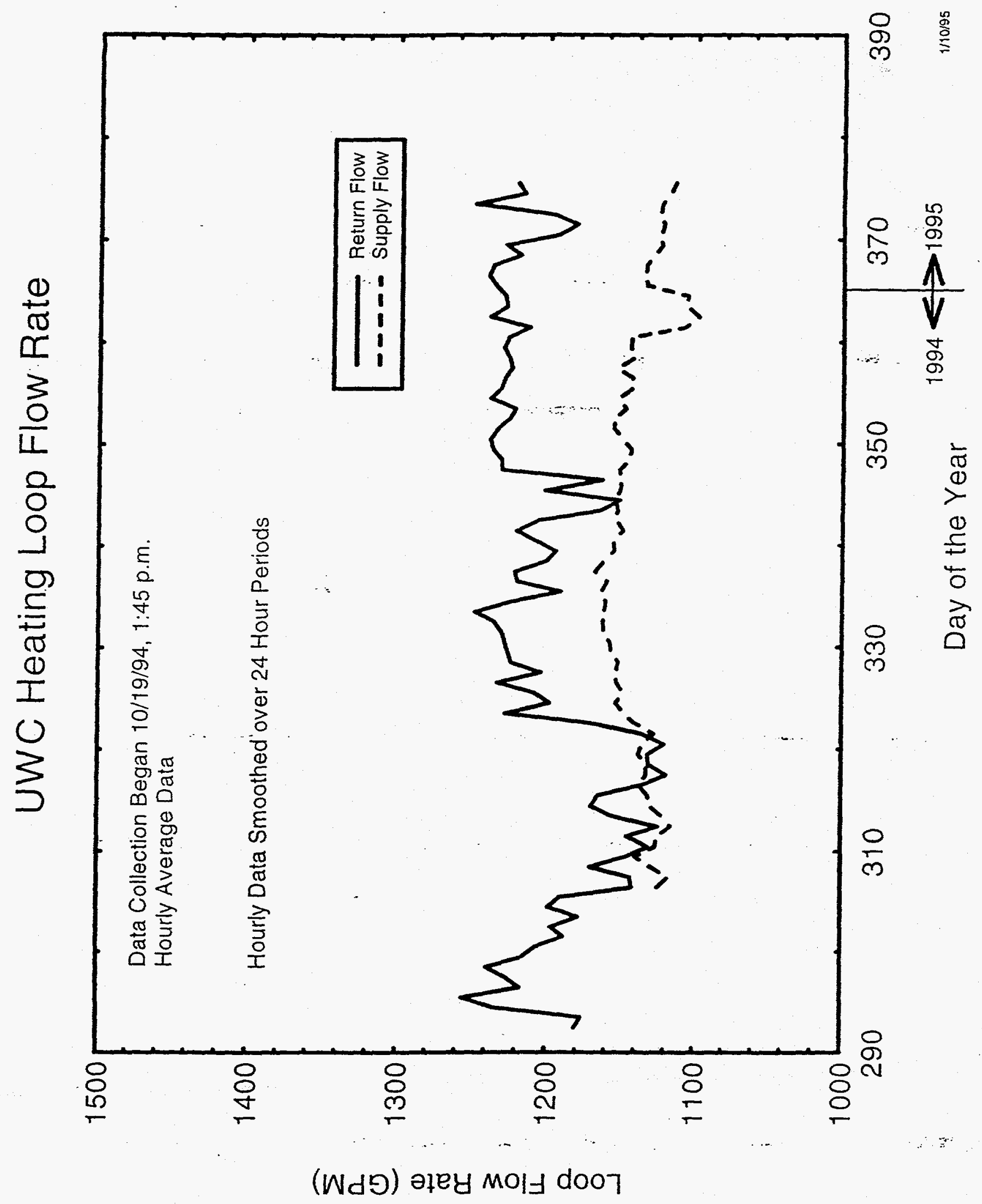




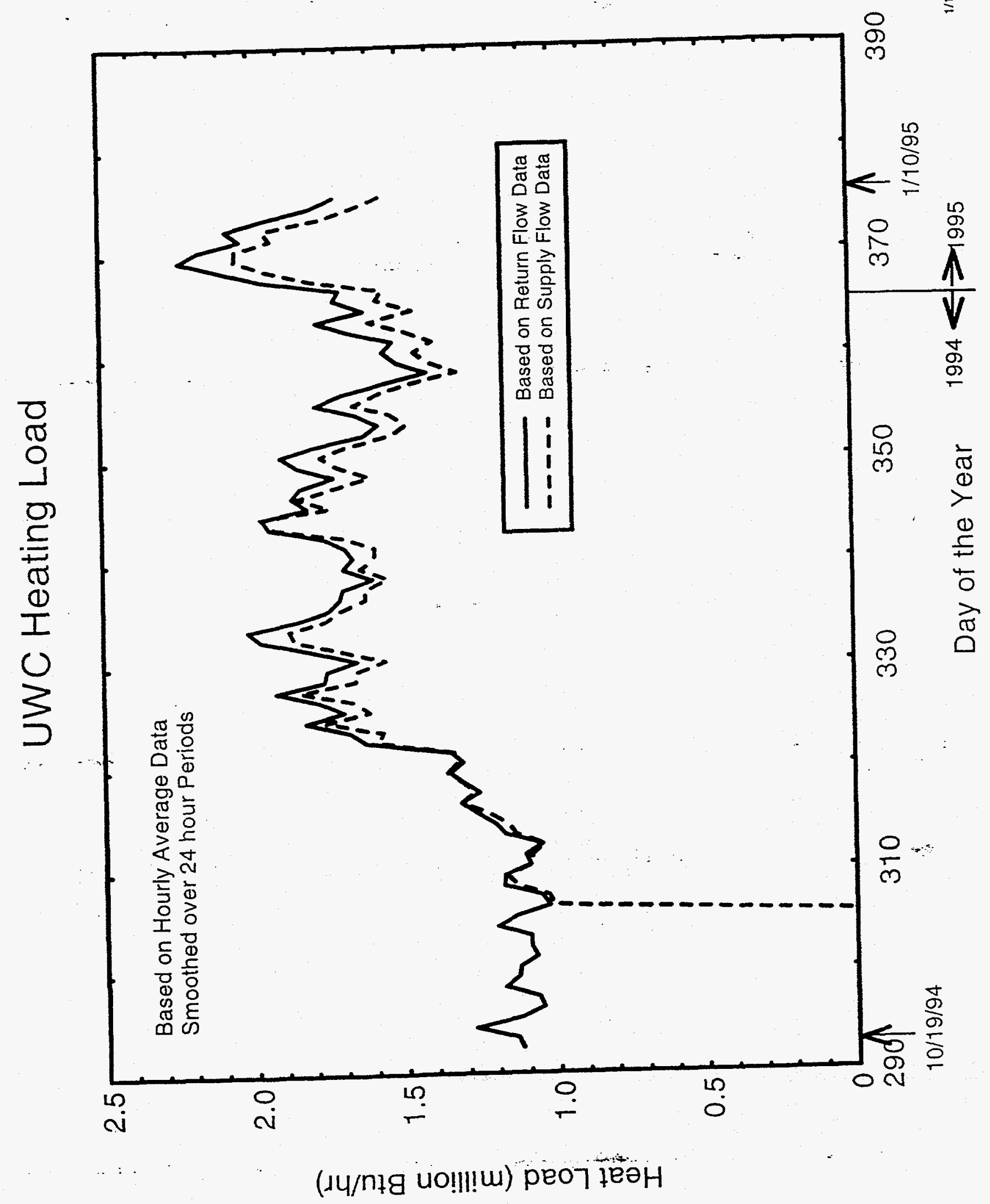




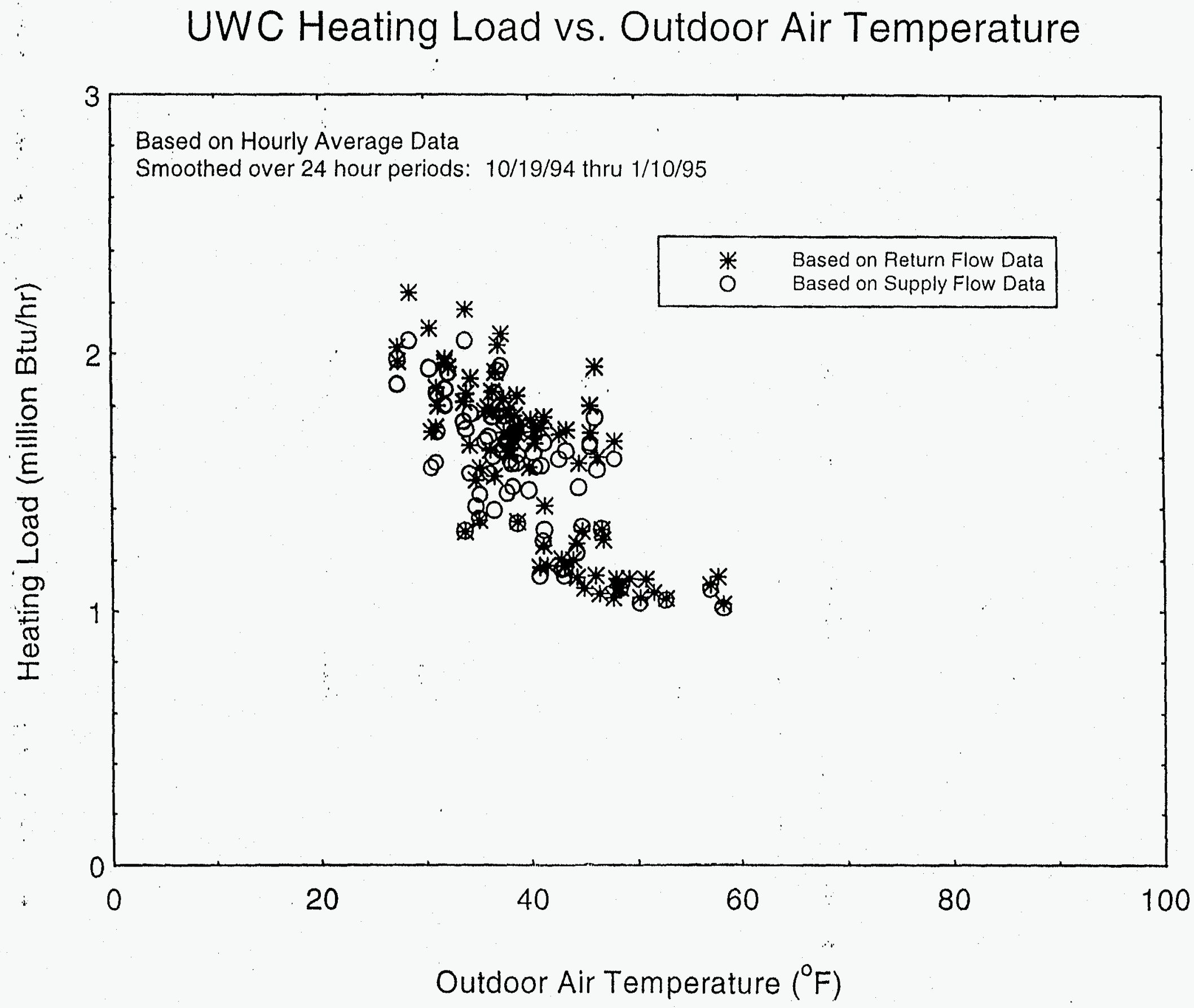




\section{Objectives

- Support of Environmental Clean-Up by Replacing a Fossil Fuel Heating System with a Geothermal Energy System.

- Enhance Local Economic Development Opportunities

to this Economically Depressed Region.

- Build Important Government and Private Industry Partnerships.

- Develop a Renewable Energy Educational Center.

- Demonstrate New HDR Technology. 
ATTACHMENT B

The Hot Springs

at

Montezuma, New Mexico

Data Collection Charts

Section 2 


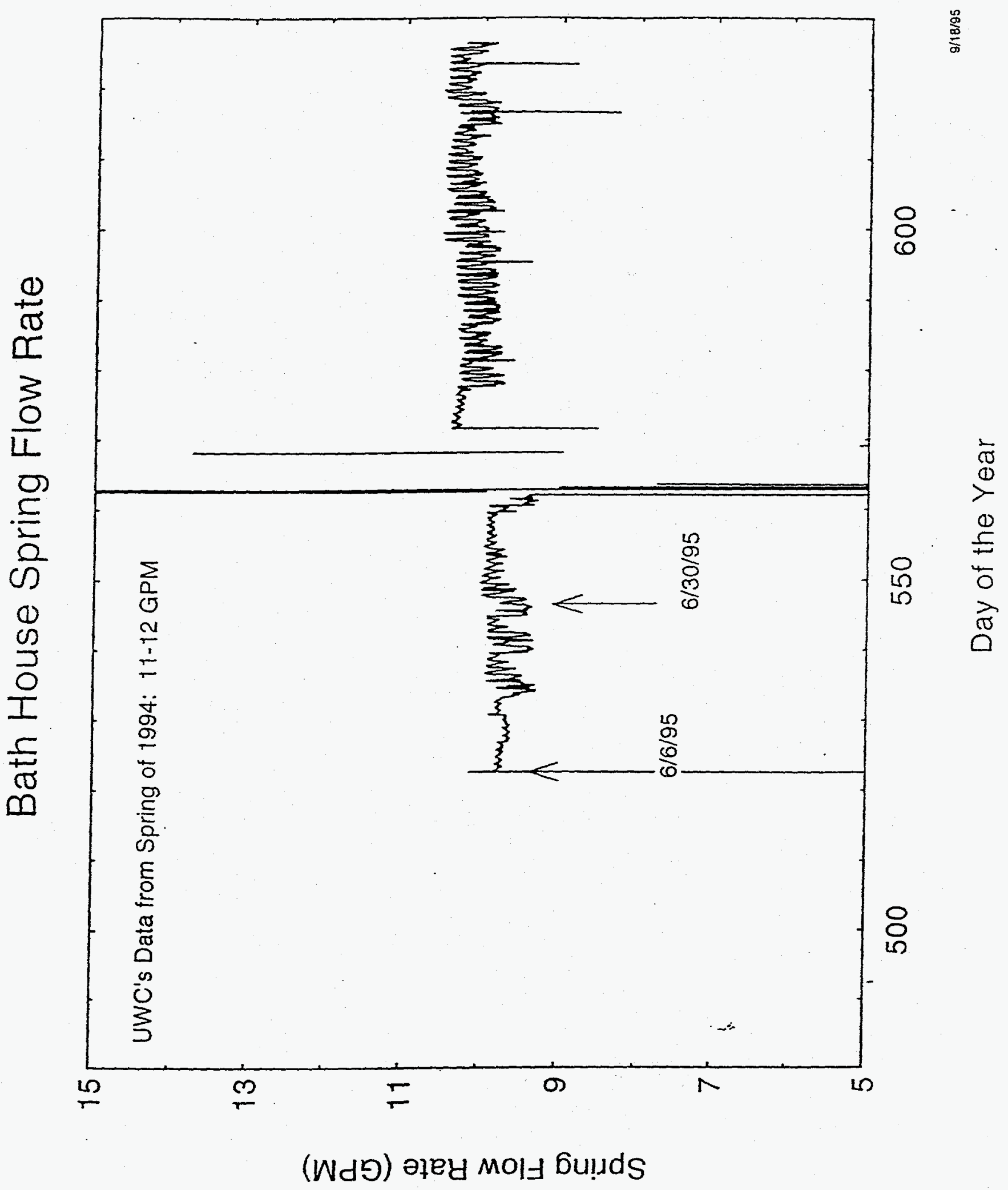




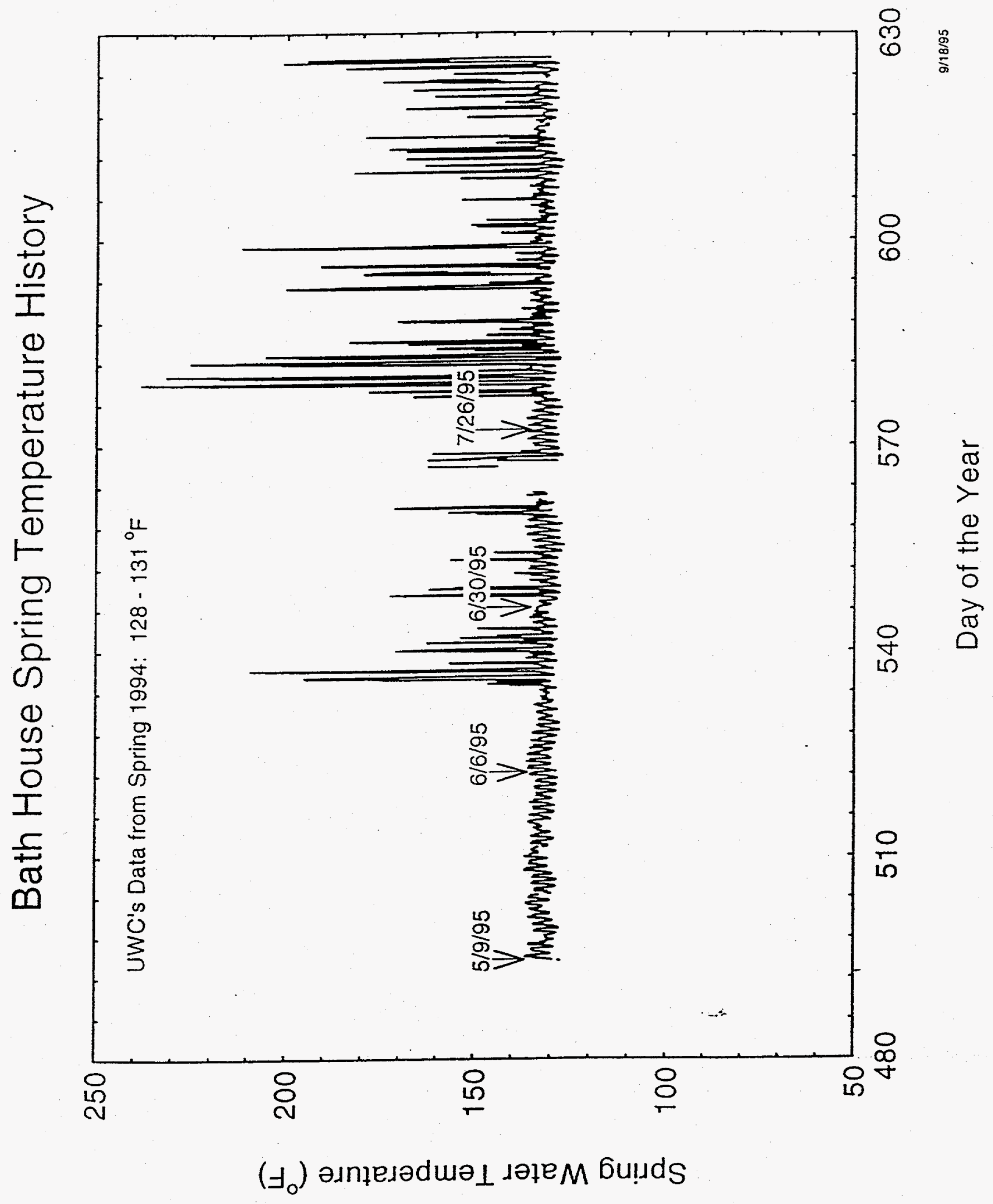




\section{UWC Heating Load using Average Flow Data}

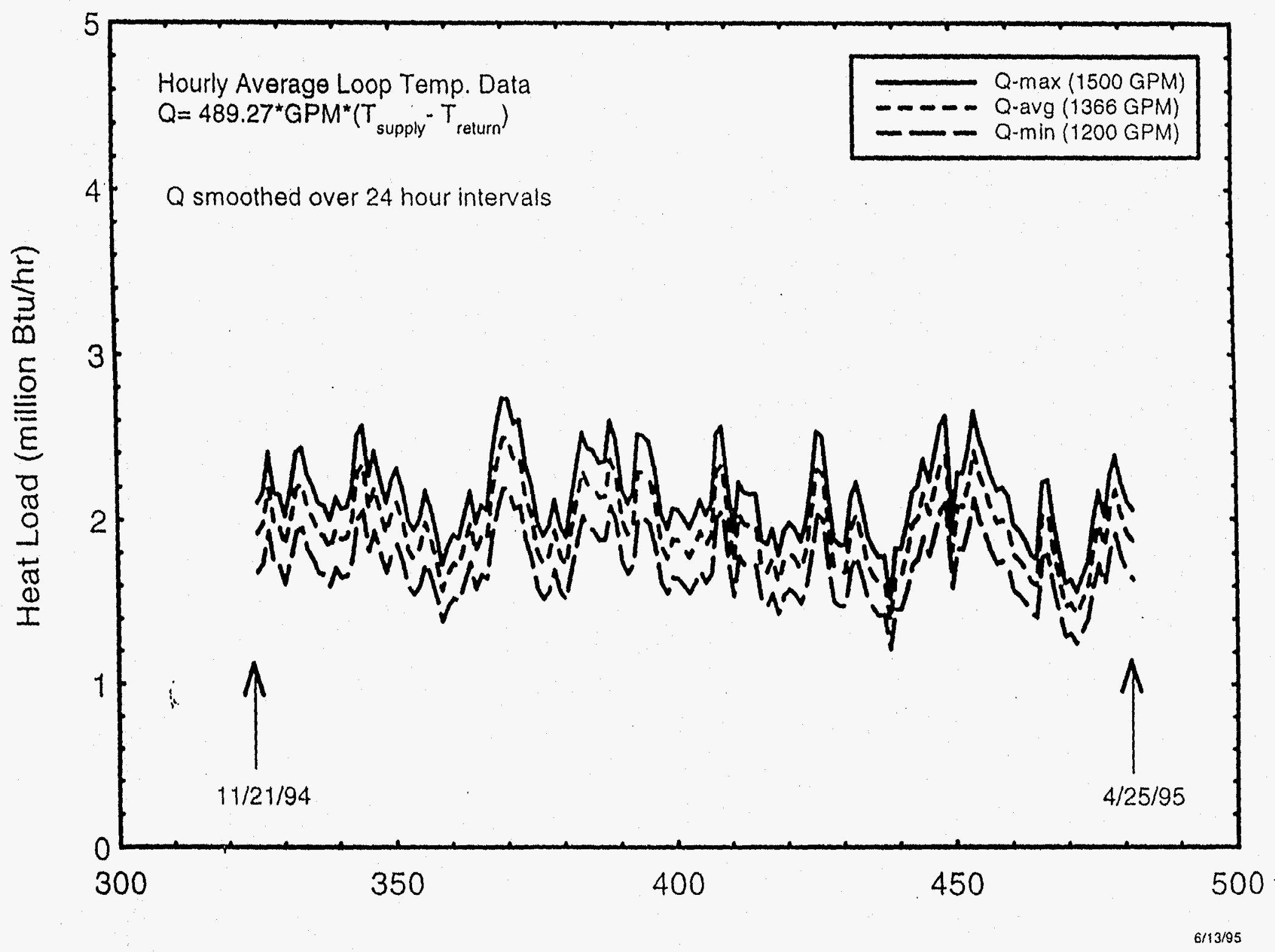

Day of the Year 


\section{UWC Outside Air Temperature}

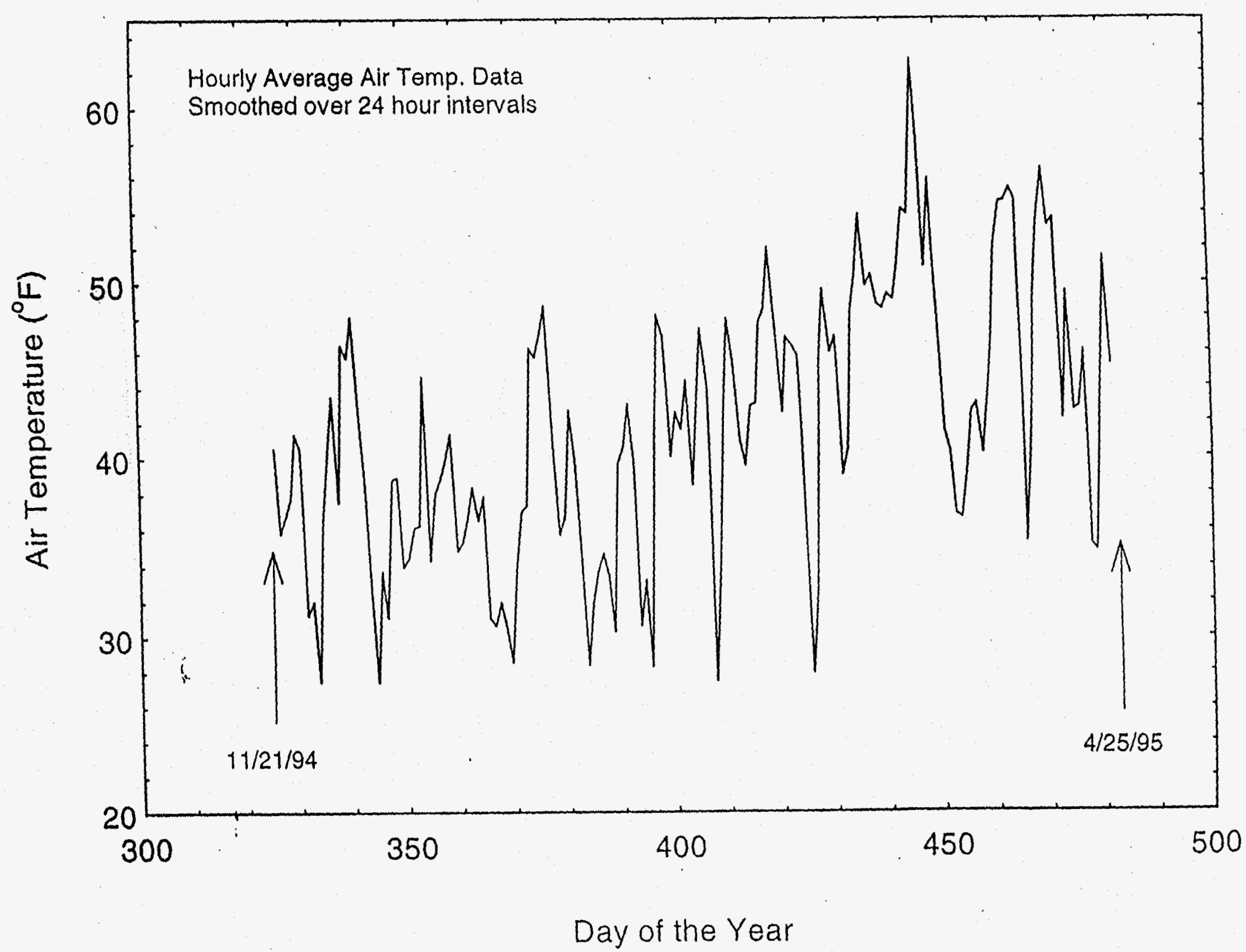




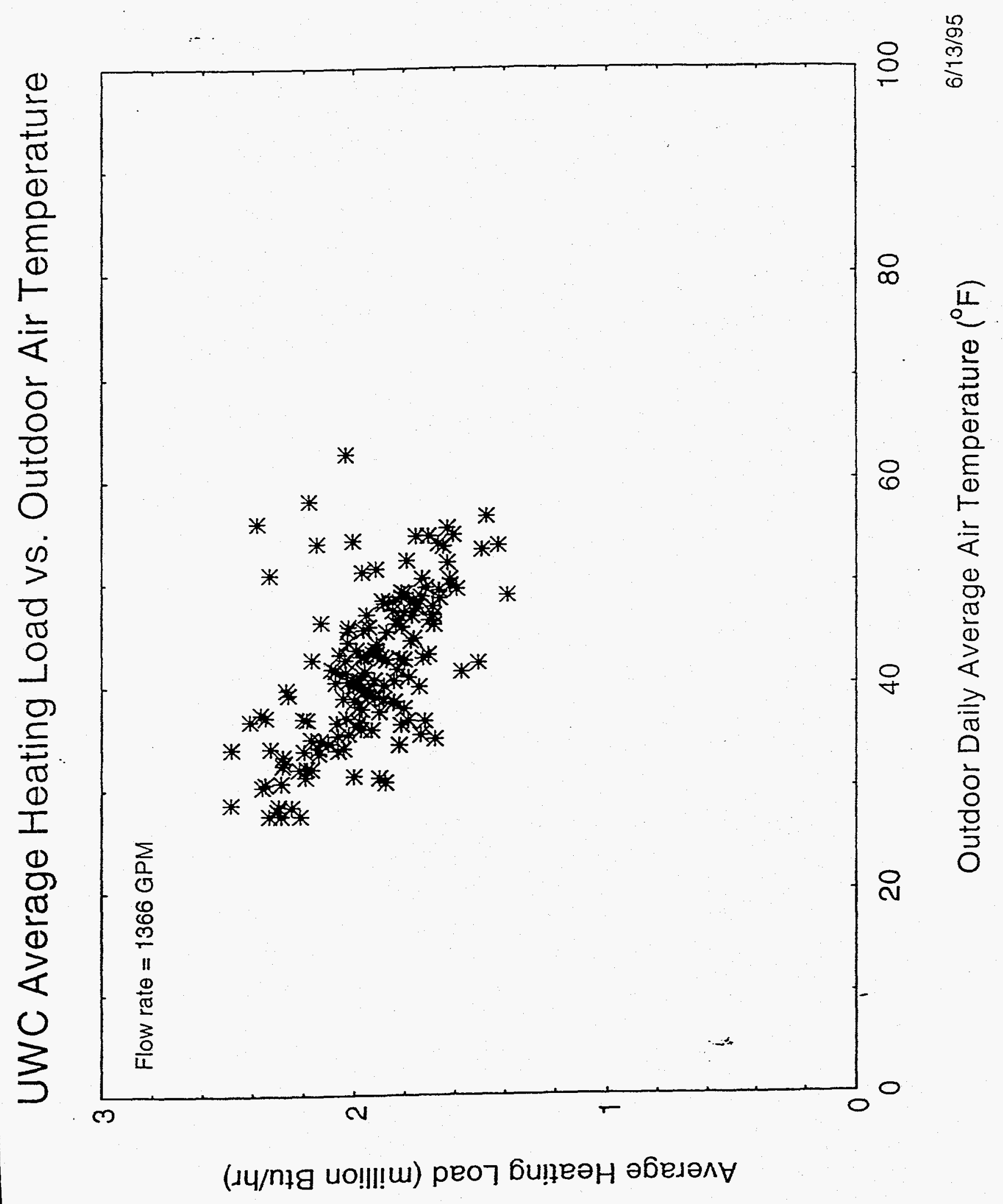




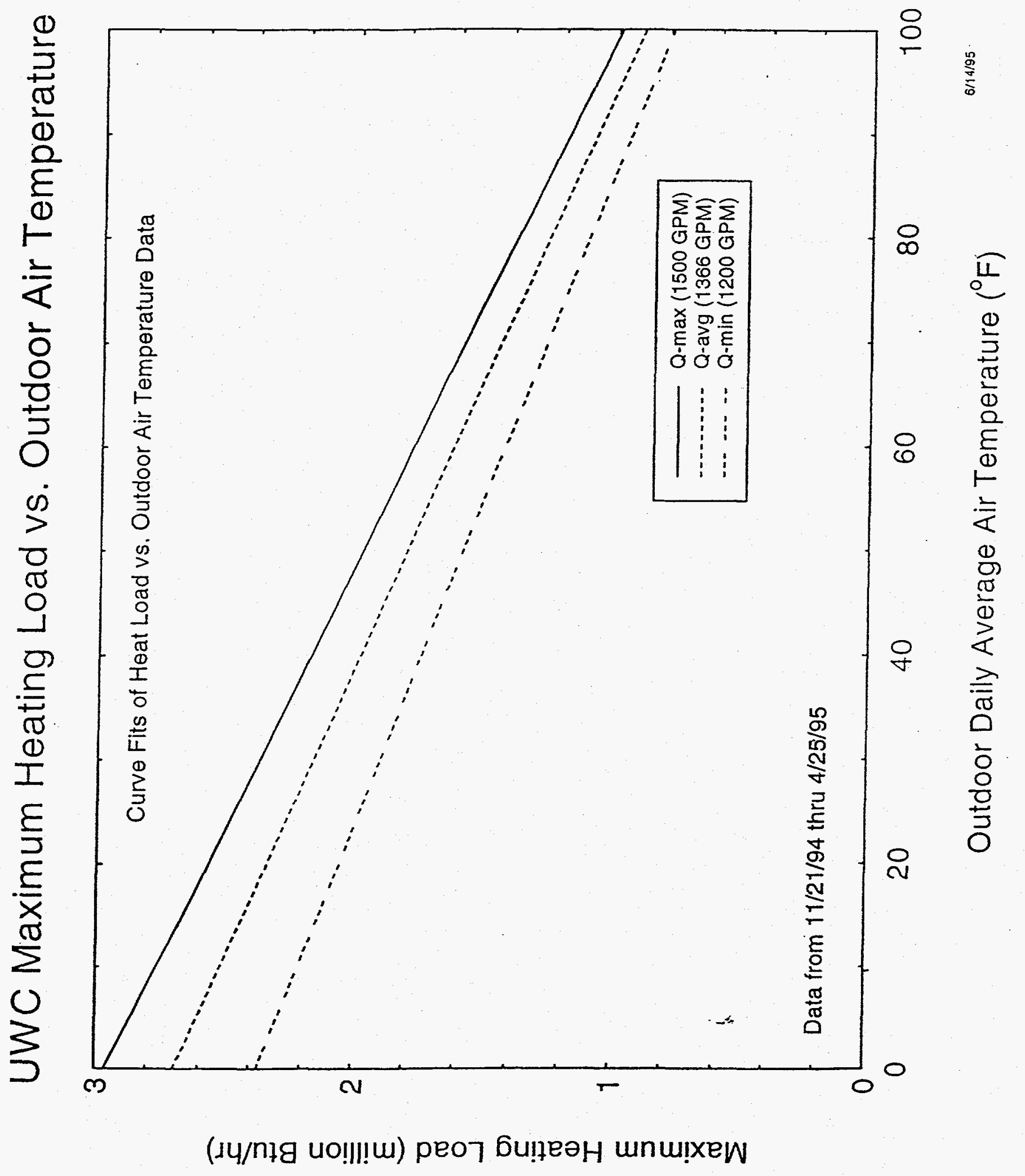


ATTACHMENT C

The Hot Springs

at

Montezuma, New Mexico

United World College Geothermal Resource

Exploration Project Overview

Section 3 


\section{United World College Geothermal Resource Exploration Project Overview}

\section{Introduction}

The Armand Hammer United World College of the American West located in Montezuma, New Mexico, is situated on property where there are numerous natural hot springs known as the Montezuma Hot Springs. Consistent with its mission, United World College (UWC) would like to urilize these natural springs for a variety of purposes not only to supplement its international educational goals, but also to promote environmental awareness and community service ideals to its intercultural student body representing 70 countries as well as the United States.

The first objective is to harness the natural power beneath the springs to replace the existing coal-burning beating plant. The college currently heats the majority of their buildings and facilities with hot water producod by this plant. They are anxious to replace the coal boiler with an alternative environmentaily friendly tecinology to both lower their space and hot water heating costs and reduce the pollutants produced by the coal-burning plant.

Larger objectives exist which will benefit not only UWC, but the local community. With geothermal power in use, the college could broaden its existing environmental studies program to include first-hand experience with geothermal/natural power issues. The working geothermal system could serve as a demonstration program not only for the college's multi-cultural student body but also extend UWC's present community service program to develop a renewable energy educational center in northern New Mexico. This would benefit the local elementary, high school, college, and community educarional opportunities in this region. Depending on the actual strength of the geothermal resource, it may be possible to use geothermal power for additional purposes beyond replacing the existing coal furnace at UWC. Examples include: 1.) generating electricity for the campus and surrounding community using stateof-the-art hot ary rock technology, 2.) developing the local well dnilling industry for geothermal resource exploration, 3.) expanding greenhouse horticulture and aquaculture industries to northern New Mexico, and 4.) strengthening the state tourism industry by enhancing the natural hot springs for public use and eventually developing this area into a state park.

All of these objectives fall within the current U.S. administration's goals to promote the U.S. as a world wide leader in the development, application, and export of environmentally clean and economically competitive renewable energy systems. Working toward these objectives will build and strengthen government and private industry partnerships as well.

None of these desired objectives are within the realm of possibility without further explorations of the geothermal potential. Drilling test wells will indicate the critical elements of heat and pressure available and is necessary to assess the feasibility of these project objectives.

Sandia National Laboratories (SNL), Los Alamos National Laboratory (LANL), and the Southwest Technology Development Institute (SWTD) at New Mexico State University (NMSU) are interested in helping UWC utilize this geothermal resource. This project is relevant to several of SNL's and LANL's research and development activities including geothermal heat pumps, slimhole drilling, downhole instrumentation and hot dry rock technologies. SWTDI has considerable experience with utilizing 
geothermal energy to provide space heating and developing greenhouse horticulture and aquaculture in New Mexico. Thus, exploration of the natural resource potential of the Montezuma Hot Springs is of significant value to the programs of UWC, the national laboratories, NMSU, the geothermal and renewable energy resourec industries, the state economy, and the surrounding New Mexican comnunity.

This overview is intended to outline the project objectives, discuss possible geothermal heating options to replace the coal-burning plant, and outline the proposed tasks needed to initiate this project. In addition, possible funding sources as well as the benefits of this project to United World College, the local community, the environment, and renewable energy technologies are discussed.

\section{Facility Description}

The Armand Hammer United World College of the American West was founded in 1982 by noted humanitarian and philanthropist Dr. Armand Hammer. It is a non-profit two-year international residential school for students 16 to 19 years of age and the only United World College in the United States. It serves as the equivalent of the 12 th and 13 grades and is a "bridging" school between secondary and university education. UWC enrolls 200 students from 70 countries and from throughout the United States who are hand selected solely on the basis of their academic merit and leadership qualities. The mission of UWC is to enable young people to become responsible citizens, politically and environmentally aware, committed to the ideals of peace, justice, understanding, and cooperation, and to the implementation of these ideals through international education, shared experience and community service.

The Armand Hammer United World College is located on property consisting of approximately 110 acres, of which about 30 acres are developed. The Gallinas River runs through the property in the southern section. The Montezuma Hot Springs are near the current coal boiler plant and are used mostly by the surrounding residents for bathing.

The college uses a boiler heating system for space heating and hot water beating for approximately 121,000 $\mathrm{ft}^{2}$ of facilities. The facilities consist of the cafeteria, administration building, campus center, fine arts center, maintenance building, other academic buildings, four dormitories, and residences for the college president and faculty. Additional residential facilities $\left(\equiv 25,800 \mathrm{ft}^{2}\right)$ are not heated by the hot water loop but rather use electricity and propane for space heating. In the furure, the heating system may need to be expanded to include these residences along with the Montezuma Castle (a large structure on the property presently not used). The boiler house contains the central heating plant where the hot water for heating is produced and pumped through a large underground loop constructed of insulated steel pipe and delivered to the buildings. The hot water is then circulated through standard radiators and fan coil units in the individual rooms for space heating.

The boiler heating system has been in use since 1982 and operates on bituminous coal which is purchased from King Coal Company in Durango, Colorado. It is trucked in year round and approximately 600 tons of coal are used annually. Decernber is usually when the peak heating load occurs and as much as 100 tons are used to meet the heating demand. The hot water leaves the heating facility at approximately $182^{\circ} \mathrm{F}$ and returns at $178^{\circ} \mathrm{F}$ and is pumped at approximately $1445 \mathrm{gpm}$ (the rated capacity of the constant speed pump). In the summer, when the demand is quite low, the water continues to circulate through the loop although a smaller pump (with a rared capactity of about $700 \mathrm{gpm}$ ) is used. Using these figures, the peak heating load is estimated at 3 million Btu/hr [1]. The average heating load assuming a 200 day heating season and 50\% boiler efficiency is estimated at 1.5 million Btu/hr [2].

The coal budget for 1993 was $\$ 35,000$ and the electricity costs were $\$ 126,000$. In addition, the annual maintenance cost is $\$ 6500$ for coal and $\$ 10,000$ for electricity. Presently, natural gas service to the college is not available. However, it will be available beginning this summer and the college has considered options to convert the boiler to natural gas at a capital cost on the order of $\$ 40,000$ to $\$ 50,000$ and an expected rise in annual fuel costs to approximately $\$ 51,000$ per year (assuming a gas boiler efficiency of $80 \%$ and a fuel cost of $\$ 0.57$ per therm). 
The Montezuma Hot Springs on the property are owned by UWC, although the local community and tourists are the major users. Though the liability insurance on the springs is a hindrance to the college, the college does not want to create poor public relations with the community by closing the springs and denying the public access to a natural resource. However, UWC would like to see this natural geothermal resource utilized to its maximum potential.

Reference 1 began to characterize the Montezuma Hot Springs area from a geothermal resource viewpoint. The area contains a number of small faults. The highest water temperanure found near the hor springs in a. shallow well at a depth of 20 feet was $133^{\circ} \mathrm{F}$. It is likely that the temperature will be much higher in deeper wells. To determine the actual geothermal potential, a thorough geological survey of the region needs to be conducted, followed by drilling of test wells.

\section{Project Objectives}

The major objectives of this proposed project include:

1. Reduce consumption of fossil fuel for space heating and water heating at UWC and in the local community. Utilization of the geothermal resource to replace the coal boiler at UWC will reduce pollution. If successful, this technology can be expanded to replace the space heating systems of other local fossil fuel users in the community such as Highlands University and the state mental hospital, in direct support of the U.S. global climate change initiative.

2. Develop and demonstrate a new world-class, economical, environmentally attractive, renewable energy system at UWC, possibly extending it into the surrounding community, in collaboration with the state and the national laboratories. While utilizing direct geothermal energy for space heating is useful, it is not a new technology. However, development of a hot dry rock (HDR) geothermal energy system to initially provide space heating with the potential to later produce electricity for UWC and the local community would be a unique, state-of-the-art, application of clean geothermal energy technology.

3. Develop a renewable energy educational center in northern New Mexico. The educational benefits of such a project will be numerous. It will enrich UWC's environmental studies program by including first hand experience with geothermal energy utilization. It will also enhance the educational programs of local schools including elementary, high school, local colleges, and state universities. It will serve to introduce and promote this technology around the world as the UWC international student body is exposed to its benefits. In addition, if a HDR facility were built, this area would receive intense interest by energy researchers around the world as well as by the general public.

4. Promote local economic development opportunities in the drilling, aquaculture, agricultural, and tourism industries. The Las Vegas, New Mexico region is economically depressed and would benefit immensely by such a project. This project would educate local water well drillers to expand their business into the exploratory geothermal resource business with the goal of reducing costs of such explorations, thereby promoting the use of geothermal resources in New Mexico. Local growers could expand their markets by building geothermally-heated greenhouses and aquaculture projects. State tourism could be boosted from the development of a state park around the hot springs as well as the development of a renewable energy educational center.

5. Build goverument and private industry partmershlps. This program would successfully demonstrate a collaborative project working toward the U.S. administration's goal of promoting renewable energy systems, the national laboratories' goals of technology development and transfer, private industries' goal of economic development, and the state goal of enbancing the educational opportunities of our youth. 


\section{Geothermal Space Heating Options}

Various options have been proposed to address the first project objective of utilizing the geothermal resource at UWC to replace the current coal boiler heating system. (See Reference 2 which is also attached as an addendum.) Each of these are briefly described below. The choice of options is very dependent on the strength of the geothermal resource and must be determined by drilling one or more test wells in the vicinity of the natural hot springs at UWC.

\section{Option 1: Direct Geothermal Heating}

If the geothermal resource is hot enough $\left(>150^{\circ} \mathrm{F}\right)$ and produces a large enough flow ${ }^{\prime}$ to support the UWC heating loads, the water could be pumped from a geothermal well and used to heat the water in the existing hot water loop through a heat exchanger or be directly injected into the hot water loop depending on the well water quality. The geothermal well would serve to replace the boiler. The boiler, however, would be retained for backup heating. The discharge from the heat exchanger, if used, could be piped back into an injection well or the river. This option proposes lowering the existing loop circulation temperature to approximately $140^{\circ} \mathrm{F}$ from the temperature now used $\left(180^{\circ} \mathrm{F}\right)$. The feasibility of this circulation temperature using the fan coil units, baseboard heating units and hot water needs must be investigated.

If the geothermal resource is sufficient to meet the peak UWC heating loads, the annual fuel costs would be minimal compared to the cost of coal currently used in the boiler (approximately $\$ 35,000$ annually in 1993). The operating costs will decrease to only the electricity charges to power the pumps. The major capital expense to implement this option is the cost of the geothermal well and heat exchanger. This is the preferred option if the geothermal resource is available.

Option 2: Geothermal Heating Augmented with Heat Pumps at the Loads

If the geothermal resource is not sufficient to meet the heating loads at UWC alone (well temperanure below $150^{\circ} \mathrm{F}$ and a flow rate below $200 \mathrm{GPM}$ ), commercial water loop heat pump units could be installed in the buildings replacing the fan coil units and baseboard radiators. This would eliminate the coal boiler except for backup heating. As in Option 1, the well water could be used to heat the existing circulating loop water to a much lower temperature using direct injection or a heat exchanger as described above. The heat pump units on each building then can operate at a loop temperature of approximately $70^{\circ} \mathrm{F}$ to supply the heating requirements.

This option will work with much less geothermal energy ${ }^{2}$ but will require electrical energy to run the heat pumps. It is estimated that the annual electricity costs to power the heat pumps would be approximately $\$ 60,000^{3}$ to meet the average annual heating load at UWC. As noted above, costs to operate the pumps would be additional. However, these costs are incurred with all options as well as the current coal boiler operated system. Capital costs for this option are also much higher than Option 1. Besides the cost of the geothermal well and heat exchanger, heat pump units must be purchased but are commercially available at a

\footnotetext{
${ }^{3}$ Estimates of the minimum flow rate required from the well as a function of well watcr temperature were made for the projected peak loads at UWC. For example, if the well temperature is $150^{\circ} \mathrm{F}$, a flow of $600 \mathrm{GPM}$ would be required to meet the peak load. If the well temperature is $200^{\circ} \mathrm{F}$, a llow of $120 \mathrm{GPM}$ would be required. (See Reference 2 for a complete table.)

${ }^{2}$ For example, if the geothermal well temperature was not hotter than $120^{\circ} \mathrm{F}$, a minimum flow rate of $100 \mathrm{GPM}$ would be sufficient assuming the heat pump operates at a COP of 3.5 [2].

${ }^{3}$ Assumes the heat pumps operate at a COP of 3.5 and the cost of electricity is $\$ 0.10 \mathrm{kWh}[2]$.
} 
reasonable cost. (See Reference 2 for a rough cost estimate.) In addition, modifications to the current building HVAC systems would be required to install the heat pumps.

\section{Option 3: Geothermal Heating Augmented by Heat Pumps at the Source}

The third option is proposed in the event that the geothermal resource is even less substantial than that needed for Option 2. For example, if the well temperature is below $150^{\circ} \mathrm{F}$ and the flow rate less than 70 GPM, a large muiti-stage heat pump could be installed at the geothermal resource to heat the well water so that it can to used to raise the existing circulating loop water temperature to approximately $140^{\circ} \mathrm{F}$ through a heat exchanger as in Option 1.

This option results in approximately the same annual electricity costs as Option 2 . This option may also be a preferred choice over Option 2 since a simpler retrofit is required; the existing fan coil units and baseboard radiators in the buildings could be utilized as in Option 1. However, a "multi-stage heat pump" will probably consist of large industrial units which may or may not be readily available.

\section{Option 4: Geothermal Heating Using Water Injection to Augment Hot Water Production}

This option invoives the application of HDR technology to inject additional water deep into the underground strata in order to boost the flow of the hot springs. The source of the additional water could be the waste-water plant at the college, the primary college water supply, or the Gallinas River. Recirculation could be employed to minimize the total net water consumption. The added water would be pumped down an injection well and heated underground to augment the flow of the springs. A second well, probably shallow, would be needed to capture the added flow. With the higher flow, the water could be used to heat the UWC facility as described uncer Option 1 and then the partially cooled (but still warm) water returned to the springs or, alternatively, the water use could be partitioned with some going to maintain the natural hot springs and the remainder being used to heat the college. This application of HDR and natural hot water geothermal technology would be unusual (perhaps even unique) and could be promoted as a novel application of geothermal technology.

\section{Option 5: Geothermal Heating Using Pure Hot Dry Rock Technology}

If the hot water resources at UWC are insufficient to meet the school's heating requirements but a moderately high temperature gradient $\left(22^{\circ} \mathrm{F} / 1000 \mathrm{ft}\left(40^{\circ} \mathrm{C} / \mathrm{km}\right)\right.$ or higher) is observed during test drilling, the development of a HDR geothermal energy system could be feasible. HDR is a demonstrated but not yet commercialized geothermal technology with the potential to revolutionize energy use around the world. A practical HDR facility at UWC would make the UWC a world-leader in the application of ciean energy technology and would lead to intense interest by energy professionals around the world as well as by the general public. The operating costs of an HDR facility would be lower than the current costs of running the coal plant, but the capital investment would be high. The project would be justified for funding primarily because of its pioneering nature. HDR requires a small but continual supply of water. At UWC, this could probably be supplied by the effluent from their waste-water treatment facility. Ain HDR facility would also be compatible with the utilization of the hot springs for recreational purposes.

All of the above options will effectively reduce the emissions at UWC to zero compared to the coal boiler system now in use. However, the choice of options is very dependent on the strength of the geothermal resource that is available.

\section{Possible Site Locations of Exploratory Wells}

In order to assess the feasibility of any of the Geothermal Space Heating Options discussed above, the strength of the geothermal resource at UWC must be determined. In discussions with LANL scientists 
familiar with the local topography and geology at UWC and initial site tours by SNL, LANL, and SWTDI representatives, four potential sites for geothermal exploratory well drilling were suggested. These are as follows:

1. Across the road south of the springs. One older shallow well has been found in this area and has standing, hot water in it.

2. In the parking lot next to the coal-fired eower plant: This location is readily accessible and would have a minimal visual and psychological impact. It is likely hot water will be accessed from this site, although the maximum possible flow may not be obainable.

3. On school property 50 to 100 yards west of the springs: This would also be a technically excellent site since the fault from which the springs emerge appears to dip to the west.

4. Up to a mile to the nerth of the spring: This site could be on the property of UWC and is located some distance from the spring but in a direction expected to produce the largest water and/or heat flow. This location would provide the most information about the real potential of this geothernal resource. It is possible and even likely that water would not be hit, but if it were, a significant geothermal resource would be indicated. The geological information obtained from the well could be very important for evaluating the geology and the HDR potential of the site as well as the bydrothermal resource.

Since seepages appear at the surface within the area of the springs near the bathhouse, it is virtually certain that hot water will be obtained and appears to be a good drill site location. However, the risk of tapping into very high pressure water must be assessed to insure a safe drilling operation and preserve the natural springs. In geothermal explorations, a surface casing must be anchored into the ground to secure blow-out protection equipment. This region is very swampy and does not appear to be a good choice from a safety standpoint.

The above site considerations are simply preliminary discussions of the inportant aspects of drilling at the four general locations mentioned. A detailed, on-site evaluation by an exper geologist will be necessary to finalize the specific site of drilling within any one of these areas.

\section{Proposed Work}

As indicated above, to assess the feasibility of any of these proposed project objectives, a determination of the strength of the resource is required. Therefore, the initial step (Phase I) involves a thorough geological survey of the hot springs area. An experienced geologist will review the existing data regarding the geology and taults of the region as summarized in Reference 1 and take appropriate field measurements to estimate the potential flow and temperature of the resource. From this geological survey and data analysis, the best locations to drill one or two exploratory test wells will be determined and may or may not be in the locations discussed in the previous section. These sites must meet safety criteria and preserve the natural hot springs area.

In Phase II of the project, one or two exploratory wells will be drilled at sites determined from the Phase I study. It is estimated that a depth of 1000 to 2000 feet will be necessary to not only determine the maximum well fluid temperature and flow potential for direct geothermal space heating applications, but also measure the thermal gradient necessary to assess the feasibility of an HDR project. A local well driller is preferred assisted by a consultant such as an industrial partner experienced in geothermal well drilling to insure well drilling safety and integrity.

The use of slim holes for the geothermal assessment should be considered. SNL is currently working with the geothermal industry to evaluate slimhole drilling for geothermal exploration and reservoir characterization. State of the art measurement techniques such as borehole instrumentation available at the nacional laboratories will be utilized for this project. LANL will examine the possibility of developing HDR technology from this resource based on their analysis of the data. 
Concurrently, the heating load at UWC must be determined more accurately with a small measurement program. The circulating water loop temperatures leaving and returning to the heating plant and loop flow rates will be monitored during the 1994 heating season. The electrical energy used by the circulating pumps will be monitored as well as the coal usage. Weather data will also be ineasured.

Based on the outcome of the geothermal assessment and the measurement of the heating loads, the future project tasks will be defined. The geothermal heating options described above and any other proposed options that appear feasible will be evaluated. This will include extending this project to provide geothermal heating to the surrounding community and production of electricity utilizing HDR technology. Note that combinations or hybrids of the options described above should also be considered. For example, if the geothermal resource is not capable of supplying the heating loads, it may be utilized in conjunction with the present coal boiler system or a retrofitted gas boiler system if these scenarios were economically feasible compared to either Options 2 or 3 . Options that are feasible will be assessed in detail in a two phase study as outlined below.

In addition to the replacement of the coal boiler system, UWC would like to preserve and enhance the natural springs area and possibly develop a state recreation area. Along with the geothermal well development plans, therefore, a design of a state recreation area will be performed to estimate the costs, time, and schedule required.

Phase II of this study will conclude by recommending the best option for further study based on the exploratory well measurements. It will include an estimate of the capital costs of each option including the costs of dismantling existing HVAC hardware, possible thermal upgrades to the buildings, geothermal equipment (i.e., geothermal well development, pumps, piping, heat exchangers, etc.) and HVAC hardware upgrades or retrofits if necessary (i.e., heat pumps, duct work, electrical wiring, etc.). The annual operating costs for each option will also be estimated based on the heating load projected to a credible bin-type weather year in the Montezuma area. These cosis will include the estimated maintenance costs as well. The total annualized cost of the options will also be calculated. Estimates of energy usage for all the options will be made and compared to the present energy usage at the college.

Once the costs and energy consumption data requested above is obtained, recommendations for the best option will be made. The criteria for this recommendation will be outlined in decail and address the project objectives discussed above.

Phase III of this study will follow with a complete and detailed engineering design study of the recommended option resulting from Phase $\Pi$. The geothermal well development and distribution system, if applicable, will be designed. All HVAC equipment as well as any additional thermal upgrades to the existing campus facilities will be specified.

The first cost, annual operating costs, maintenance requirements and costs, the total annualized cost, and energy consumption estimates will be determined and compared with the present HVAC system as described under Phase II. The schedule for the conversion project will be estimated and the impact on the college's academic or summer operations will be detailed.

We estimate the cost of Phases I and II (including the geological survey, drilling and monitoring the test wells, analysis of the data, documenting results, and recommending the Phase MI option) at approximately $\$ 280,000$. This is in addition to the contribution valued at approximately $\$ 100,000$ from UWC which includes their donation of the exploratory drilling site, faculty, staff, and facility maintenance support, and expansion of their community service projects. We believe a Phase III engineering design based on the exploratory well data could be completed for $\$ 100,000$.

\section{Building Partnerships}

This project lends itself well for building government and private industry parnerships to increase the economic development of the northern New Mexico region. Both the state and federal government can contribute to promote the U.S. administration's goals of development of clean, environmentally friendly renewable energy technologies. The national laboratories can contribute their technical expertise for the 
development of renewable energy technologies and transfer these technologies to private industries. Their support will promote and establish economic development for the local drilling industries, independent power producers, agriculture, aquaculture, and tourism industries in the state of New Mexico. Through UWC's interest and participation, educational programs within the community and worldwide will be enhanced. This collaborative effor will serve as a model for public and private sector cooperation.

\section{Funding Sources}

Possible government funding sources for the initial geothermal resource assessment and heating load measurement program include the Department of Energy (DOE) under the global climate change and drilling program funds, the National Science Foundation (NSF), and the State of Niew Mexico through petroleum escrow funds or through the Environment Department and the Energy \& Minerais Department. UWC has committed to contributing the exploratory drilling site, faculty, staff, and maintenance support, and expansion of their community service projects. The value of their contributions is estimated at approximately $\$ 100,000$. Possible private industry collaborators such as drilling companies (Pro Drill. Occidental Petroleum, local drillers), utilities (Public Service Company of New Mexico, and independent power producers), and local agricultural business interested in expanding their markets with greenhouse horticulture and aquaculture may fund portions of the design and feasibility studies once the resource has been characterized.

\section{Benefits of Project}

The benefits of this project are numerous and target not only UWC but also the local community through enhanced educational opportunities, environmental clean-up, the advancement of renewable energy technologies, and increased economic development. Replacing fossil fuels with clean geothermal energy resources will certainly contribute to reduced emissions and support the global climate change initiative. If the geothermal resource is substantial, UWC may become the site of a demonstration project of the most advanced, world-class, 21st Century application of clean renewable energy technology in the world which may not only supply heating but also electric power generation to the local community. This demonstration project will also provide an enormous educational opportunities to the international student body at UWC, the local elementary and high schools, the nearby colleges, the state universities, and the general public. $A$ renewable energy educational center will be started at UWC to promote the educational benefits worldwide. Economic development within the local drilling, agricultural, and tourism industries will be promoted. And this project will foster important government and private industry partnerships aimed at the U.S.

administration's goal of promoting the U.S. as a world leader in the development, application. and export of environmentally clean and economically competitive renewable energy systems.

\section{References}

1. Nickerson, Mark D.. "Montezuma Hot Springs - The Armand Hammer United World College: A Geothermal Feasibility Study", Draft paper, August? 1993.

2. Sullivan, W. N., Martinez, G. M., "Geothermal Heating Options at United World College", Presentation viewgraphs, March 11, 1994 (attached as an addendum). 


\section{ATTACHMENT D}

The Hot Springs

at

Montezuma, New Mexico

Hydrogeochemistry and Biota of the Montezuma Hot Springs, New Mexico 


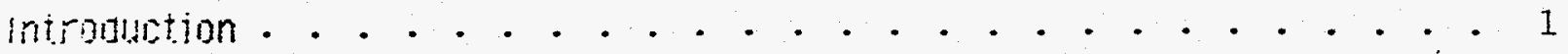

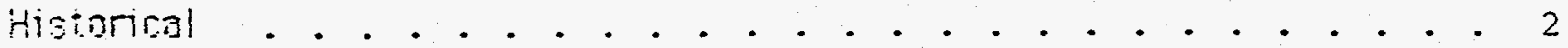

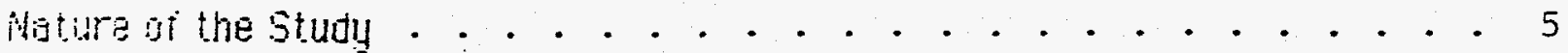

Froceriures

Locations for measurament and sampling . . . . . . . . . . . 7

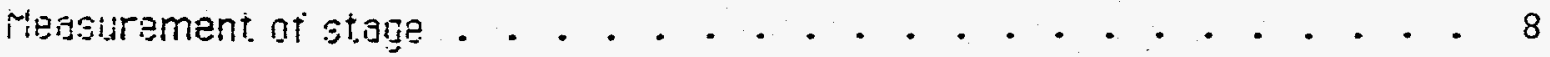

Eiver flow measuraments. . . . . . . . . . . . . . . . . . 9

Spring how messuraments . . . . . . . . . . . . . . . . . . 10

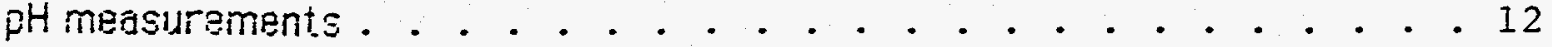

Conductivity measuraments . . . . . . . . . . . . . . . . 12

Laboratory measurements . . . . . . . . . . . . . . . . 13

Field biology . . . . . . . . . . . . . . . . . . . 14 Pesults

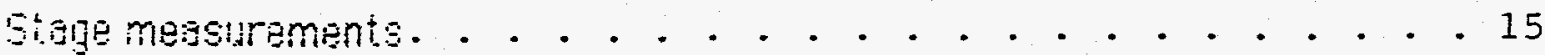

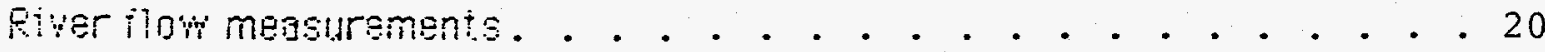

Spring tlow meseuraments . . . . . . . . . . . . . . . . 31

Chemical and physicai anglyges . . . . . . . . . . . . . . . . 41

Tritium analysos. . . . . . . . . . . . . . . . . . . 48

Totol spring ilow . . . . . . . . . . . . . . . . . . . . . 48

cisolued oxugen, biological oxygen demand and bacteris. • • • • • . . 52

Plant and algae species. . . . . . . . . . . . . . . . . • . . 54

orecussion

Sampling and measuring locations . . . . . . . . . . . . . . 55

Riverilon. . . . . . . . . . . . . . . . . . 56

Spring ion . . . . . . . . . . . . . . . . . . 57

Temperature . . • . . . . . . . . . . . . . . . 58

pH and conductivity . • . . . . . . . . . . . . . . . . 59

Chemical analyses . . . . . . . . . . . . . . . . . . 59

Eenthermometers . . . . . . . . . . . . . . . 62

Totial springs discharge . . . . . . . . . . . . . . . . 63

Acknowlengements. . . . . . . . . . . . . . . . . . . 66

References. . . . . . . . . . . . . . . . . . . 67 


\section{HYDROGEOCHEMISTRY AND BIOTA OF THE MONTEZUMA HOT SPRINGS, NEW MEXICO}

\section{Introduction}

Defure recurued history, the Montezuma hut springs were used by Indians. The legend of their use by the Aztec chief Montezuma, and hence their current name, was propagated by Indians. The legend may be true, or it might have been used to appease or confuse the white man. During the Civil War the union army used the springs for convalescence of wounded soldiers Local women made extensive use of the springs for washing clothes. In the lotter half of the 19th century the property changed hands numerous times, for increasing sums of money. Small hotels, then larger, were built by varinus entrepreneurs to capitalize on the presence of the springs. Severial uathouses were built. The last major one was destroyed in a floud in 1904 Several years before that the third large Montezuma Hotel had become unprofitable, and the tourist industry ended in Montezume. The hotel and property had several reincarnations as a Eaptist college and Mexiran Catholic Jesult seminary. It is presently owned by The Armand Hammer United World College of the American West. The costle is no longer in use; the college occupies buildings which include an old stone hotel built in is80. Most of the others were built during the time of the seminary [i] The present hesting sustem for the college utilizes hot water proutuced ty a coul-fired boiler. To reduce pollution and heating custs, the college his initisted an investigation of the geothermal potential of the hot springs, in collaboration with Los Alamos National Laboratory (LANL). Sandia National Loboratories, and the Southwest Technology [evelopment institute at Wew Mexico State Unversity. The work reported here is directed towards gaining information about the source, age, quantity, and properties of the water of the hat springs to heip in the evaluation of their yeothermal potential and to establish baseline data from which the influence of extraction of hot water from the geothermal system can be determined. 


\section{Historical}

Information on the Montezuma Hot Springs and the nearby Gallinas River has been aysilable since 1869, not long af ter the first permanent settlement in the area in 1885. The last major allocstion of water to users along the Gallinas River was made by the U.S. District Court for the District of New Mexico in 1933 [2]. The "Hope Decree" allocated 200000 gallons per day to the "college" through the "Montezuma College Pipe Lire" and also allowed the use of water of the hat springs for domestic use and for heating and bathing purposes. In addition, 1.5 acre ieet per year were allowed for irrigation for each of 21.9 acres. From the "Vigil Ditch" the college was allowed 1.5 acre feet for each of 10.8 acres. In a 1991 hydragraphic survey report the Archdiocese of Santa Fe is listed as the owner of 21.9 of these acres [3]. Eecause the college no longer uses its earlier water rights, they are no longer assigned to it.

The number of springs reconded has varied with time.
1669
20 - 30 springs (Ret [4])
1001
22 springs (Ref. [5]])
1605
40 springs (25 excaugted and walled)
$\left(30\right.$ produced wister at $120-140^{\circ} \mathrm{F}$ )
(20 connected to the main bathhouse) (Ref. [6])
189940 springs (This may rely on information from 1885) (Ref. [7])
196512 wells. 3 pipes. 13 points in the Gallinas River relegsing water at abnve amtient temperature, unspecified number of seeps (Ret. (0))
19944 groups of wells or baths; 3 are used for bathing

Estimates of flow from various springs have been made over many years, with greatly varying results. Comparisons are made difficult by the fact that in earlier years the spring tested may not be specified, or may be numbered accoraing to a plan which is no langer avallable. Springs nave been rerouted nver the years, and roodwork above the springs may have had an effect on flow. Figure 1 [9] shows the location of springs gs of 1966, with numbers to distinguish them. These locations are escentially unchanged in 1994. All references to spring numbers below are keyed to Figure 1. 


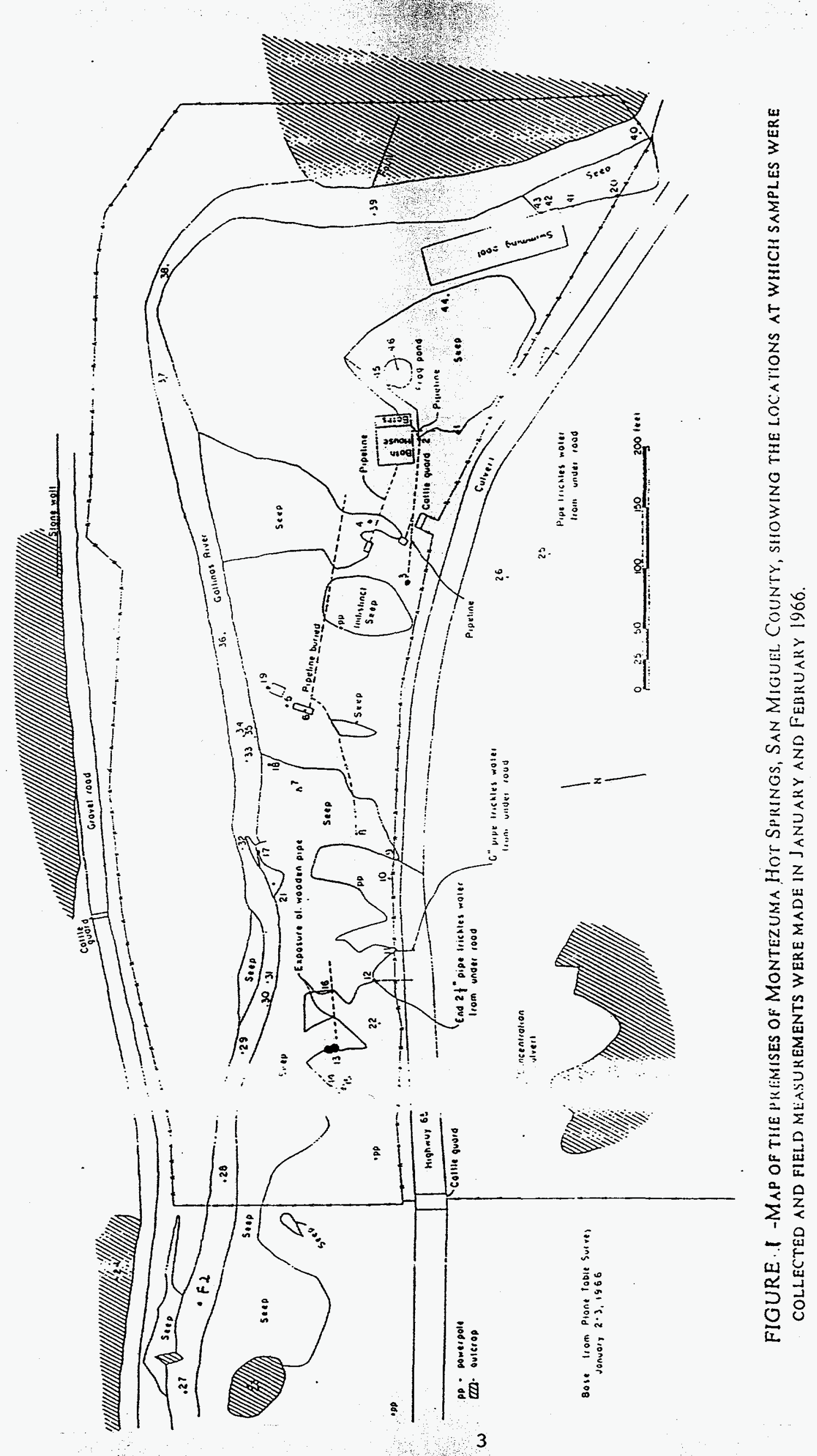


1865 One spring produced 30000 gal. per day (21 gal. per minute or $80 \mathrm{dm}^{3} \mathrm{~min}^{-1}$ ) (Ref. [6])

1952 Two springs produced 5 and $1 \mathrm{gpm}$ (i9 and $4 \mathrm{dm}^{3} \mathrm{~min}^{-1}$; perhaps spring *6) (Ref. [10])

19666 wells and several pipes produced a total of $23.3 \mathrm{gpm}\left(66.5 \mathrm{dm}^{3}\right.$ $\left.\mathrm{min}^{-1}\right)$; the largest flow was at *1 with $5.8 \mathrm{gpm}\left(22 \mathrm{dm}^{3} \mathrm{~min}^{-1}\right)$; $5.2 \mathrm{gpm}\left(20 \mathrm{dm}^{3} \mathrm{~min}^{-1}\right)$ flawed from springs $* 5$ and $* 6$ to the seminary (Ref. [8])

$199315 \mathrm{gam}\left(57 \mathrm{dm}^{3} \mathrm{~min}^{-1}\right)$ from *1; $4 \mathrm{gpm}\left(15 \mathrm{dm}^{3} \mathrm{~min}^{-1}\right)$ and 1.5

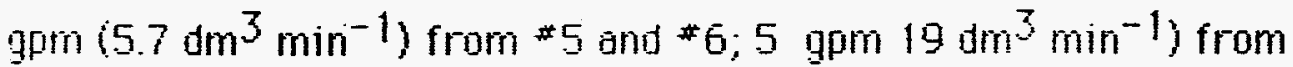
$* 13$ (Ref. [11])

Total fiow from the springs was measured in 1966 by the U.S. Geolugical Survey by taking the difference bet ween river flow measurements shove and below the surings (locatian 24, Figure 1; gauging station downstream). The vilue obtamed was 325 gallons per minute $\left(1.23 \mathrm{~m}^{3} \mathrm{~min}^{-1}\right)[12]$. In 1993 an estimate was made by adding to the measured flow of 26 gpm from four sorings a guess of 5 gpm for the seeps, giving a total flow of 31 gallons per minute $\left(1.2 \times 10^{2} \mathrm{dm}^{3} \mathrm{~min}^{-1}\right)[11]$.

Maximum temperatures also show appreciable differences with time, althugh the pattern is that of high temperatures in early years, and lower at present. The temperstures given below sre those reported for the hat test spring (s). They are given in both degrees Fahrenheit and Lelsius. No records of continuous monitoring of temperatures heve been found, al though it is known that individuals have done this without leaving teconds of their results.

\begin{tabular}{|c|c|c|c|}
\hline 1609 & $140^{0} \mathrm{r}$ & $60^{\circ} \mathrm{C}$ & (Ref. [4]) \\
\hline 1665 & $140^{\circ} \mathrm{F}$ & $60^{\circ} \mathrm{C}$ & (Ref. [6]) \\
\hline 1899 & $140^{\circ} \mathrm{F}$ & $60^{\circ} \mathrm{C}$ & (Fet. [7]) \\
\hline 1940 & $130^{\circ} \mathrm{F}$ & $>54^{\circ} \mathrm{C}$ & (Frobably spring $* 1$, Figure 1) (Ref. [10]) \\
\hline$! 960$ & $130.1^{\circ} \mathrm{F}$ & $54.5^{\circ} \mathrm{C}$ & $\begin{array}{l}\text { (Spring }{ }^{*} 1 \text {, Figure } 1 \text {, at surface; } 552^{\circ} \mathrm{C} \text { at bottom) } \\
\text { (Ref. [13]) }\end{array}$ \\
\hline & $131.2^{0} \mathrm{~F}$ & $55.1^{0} \mathrm{C}$ & (Rer. [11]) \\
\hline
\end{tabular}

Many anduges of the chemistry of the waters have been made, and these show much greater consistency than the other data. In Table I below are 
Giveri representotive duto for chloride, fluoride, silice, und sodium. Yolues are given as ppm, and calculated where necessery fram other units. Where and!yses were made of different springs, the number $(N)$ of analyses are given. the range of values, and the average and standard deviation.

Iöble 1: Selected Falues from Previous Chenical Analyses of the Montezuna Hot Springs, Hev Mexico

\begin{tabular}{|c|c|c|c|c|c|}
\hline Aest & {$\left[\mathrm{Cl}^{-}\right]<\mathrm{mm}$} & 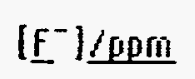 & {$\left[\mathrm{SiO}_{2}\right] / \mathrm{gam}$} & {$\left[\mathrm{Hag}^{+}\right]$/pam } & Reference \\
\hline \multirow[t]{2}{*}{1869} & $\begin{array}{l}N=3 \\
148-166\end{array}$ & & \multirow{2}{*}{\multicolumn{2}{|c|}{$\begin{array}{l}N=2(\text { traces in } 1) \\
10.4-25.1 \text { ("silicic acid") }\end{array}$}} & [4] \\
\hline & $160 \pm 10$ & & & & \\
\hline \multirow[t]{2}{*}{1682} & $\begin{array}{l}y=21 \\
142-175\end{array}$ & & $\begin{array}{l}H=17 \\
44.1-99.7\end{array}$ & & (6) \\
\hline & $160 \pm 7$ & & $66 \pm 13$ & & \\
\hline 1809 & $\begin{array}{l}\mathrm{j}=17 \\
152\end{array}$ & & $\begin{array}{l}N=17 \\
599\end{array}$ & & [7] \\
\hline 1910 & $\begin{array}{l}n=1 ? \\
3=1\end{array}$ & & & $\begin{array}{l}N=1 ? \\
9.5\end{array}$ & [14] \\
\hline \multirow[t]{2}{*}{$1959-5$} & $\begin{array}{l}4=5 \\
154-160\end{array}$ & $\begin{array}{l}N=2 \\
20,20\end{array}$ & $\begin{array}{l}H=2 \\
59,68\end{array}$ & & {$[15]$} \\
\hline & $157+3$ & 20 & 64 & & \\
\hline \multirow[t]{2}{*}{1060} & $\eta=!$ & $\frac{N}{2}=!$ & $\eta=1$ & $N=9$ & {$[16]$} \\
\hline & 60 & 3.4 & 80 & $173+24$ & \\
\hline \multirow[t]{2}{*}{1993} & $\begin{array}{l}3=5 \\
175-182\end{array}$ & $\begin{array}{l}y=3 \\
21.3-22.6\end{array}$ & $\begin{array}{l}n=3 \\
65-73\end{array}$ & $\begin{array}{l}N=3 \\
170-177\end{array}$ & [11] \\
\hline & $179+3$ & $22.1 \pm 0.7$ & $68 \pm 5$ & $174 \pm 4$ & 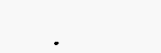 \\
\hline
\end{tabular}

\section{Nature of the Siudy}

The current investigations have been undertaken to obtain more information about the nature and source of the hot springs, and to develop educatlonal materials which will be useful rar students in educatlonal institutions. 
Tasks undertaken include measuring total discharge of water from the springs into the river; comparing the chemistry of different springs to determine if they have a common source, and the nature of that source; and monitoring the rate of flow and temperature of different springs over a period of one year to see if variations exist and if so, whether they are related to local precipitation, river flaw, and other weather conditions. In addition, measurements of dissolved axygen, biological axygen demand, and identification of organisms, mainly cyanobacteria, were also carried out.

Several approaches could te token to messurement of total spring discharge. Measuring the flow of each spring is not possible because many exist os seeps without a cleorly defined source, and others emerge within the river. The most direct method possible is to measure the rate of flow of the river above and below the the area of the springs, with the difference being at tritutable to the discharge of the springs. Several problems vere encountered with this approach. Most of the time, the flow of the river is so much greater than the discharge of the springs that the contribution of the lat ter to the overall flow cannot be measured with any reliability. Reliatie measurements can be made anly when the flow of the river is very low, and during the time of this study this condition was met for anty a relatively small number of days in late July. Even during this period, the lewei of the river changed constantly, as a result of diversions upstresm ty the oty of Las vegas for its municipal water supply, and by individuals for irrigation and stack pands. This change of the river during flow measurements amolified the uncertainties inherent in the method. A third prodiem wos encountered in incating places suitatie for flow measurements. A sutato place wos found downstream, but twa diferent sites had to be found upstream -- one for low flow and another for relotively high flow, se neither of these places, nor any other clase to the upper level of the hot springs, were suitsble for all conditions. The main problem was extreme unevenness of the stream bed caused by scattered rocks and boulders. At the high flow site velocity was too slow to measure at law flow; at the low flow site, the width and path of the flaw changed greatly except at low flow. These problems have an impact on all methods of measuring discharge, since ail methods require messurements of stream low above the hot springe. Since measurement of stream flow is a timeconsuming task, an attempt was made to relate measurements of rate of flow with depth, or stage of the river, above and below the hot springs. This Eventually should allow a rapid measurement of stage to be immediately translated into rate of flow. 
Alternative methods of measuring stream flow are indirect and involve treating the system as a dilution problem.[17] The concentration of some substance must be measured in the springs and in the river above and below the springs. If the flow of the river above the springs is known, the discharge of the springs can be calculated according to the following formula:

$$
\begin{aligned}
V_{s}=Y_{i}\left(C_{f}-C_{j}\right) /\left(C_{s}-C_{f}\right) & \text { (equation 1) } \\
\text { where } Y_{s} & =\text { discharge of the springs } \\
Y_{j} & =\text { dischange of river above springs } \\
C_{f} & =\text { concentration of substance in river below springs } \\
C_{i} & =\text { concentration of substance in river abuve springs } \\
C_{s} & =\text { concentration of substance in springs }
\end{aligned}
$$

The concentrations con be measured by conductivity or in terms of a epeciite chemical substance. Such a substance should te present in relativelu high concentration in the springs and relatively low concentration in the river. Choride and sodium ions best meet these criteria, but where passible more lons shauld te used and the colculated results averaged. Charide and sodium lans have the additional sdvantage that they are relatively easy to determine by methods accessible to students.

Another analysis worth exploring for educational purposes is the determination of silice (Sigh). This can be measured colorimetrically and is useful as a geothermometer to estimate the temperature at which the. urdergraund water is in equilibrium with the rock.

\section{Proceduras}

\section{Ingafinns for Megsurements and Sampling}

Sorings sampled gre located in Figure 1 by numbers. The following nómes or descriptiuns have teen used within this report in place of the numbers:

1. Bothhouse spring

6. Central spring, also spring under slab, or concrete slat

9. Seep near road

13. St Michaels spring 

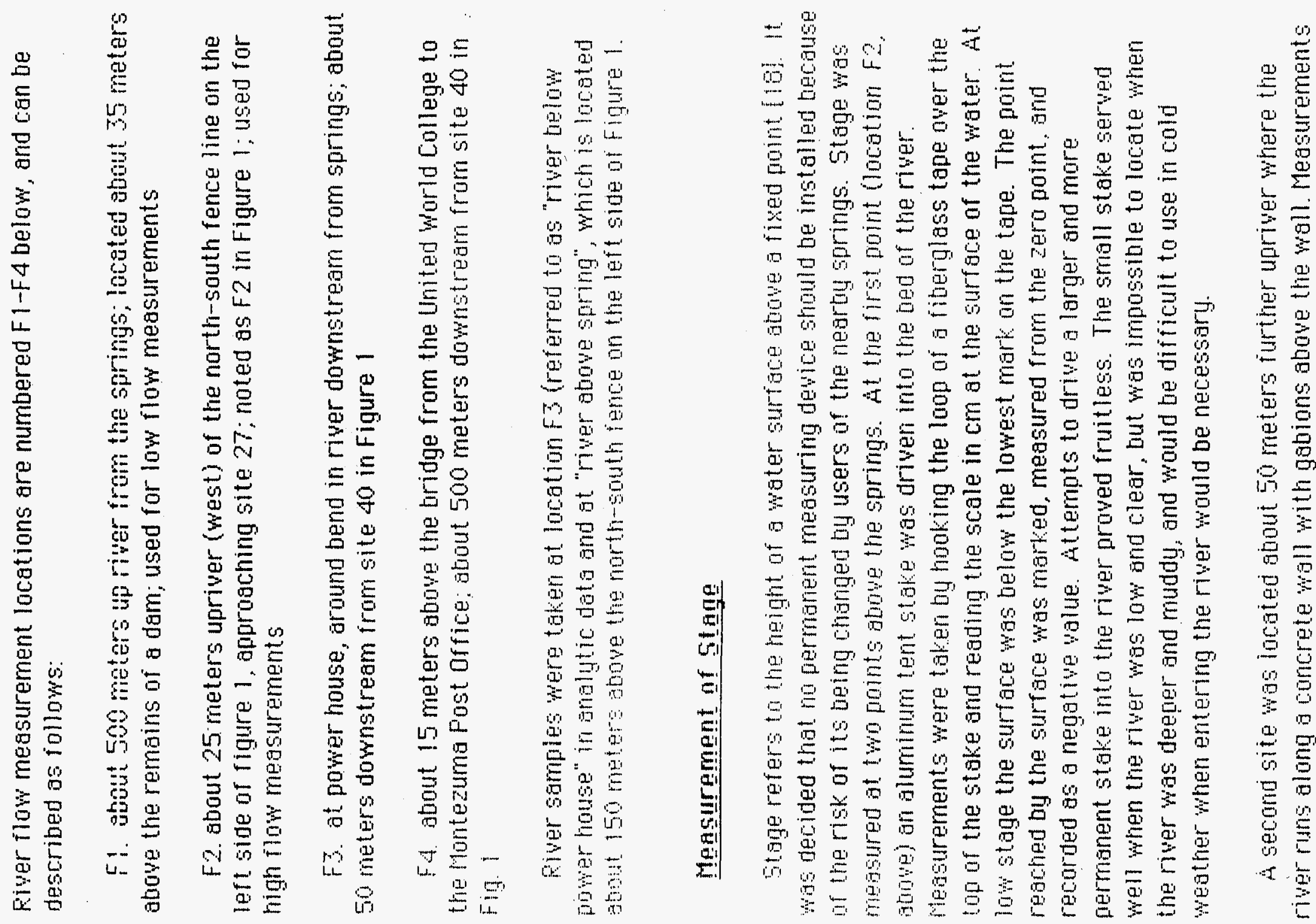
can te taken while standing on the wall, above the river. A two-inch Pve pipe about one meter in length was held vertical at a specified location where the bottom of the river is solid rock. A small amount of powdered cark was poured into the tube, and a meter ruler was lowered until it touched the rock bottom. When the ruler was withdrawn the depth could be read frum where the cark adhered to the ruler. These measurements are referred to as gauge readings.

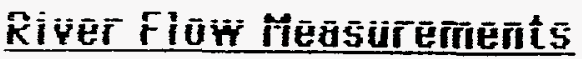

Stream flow was measured with a Swoffer Instruments Model 2100 current velocity meter with a digital readout. Readings were averaged intemally at 20 -second intervals, and five readings were taken at each location The meter gave depth measurements which were estimated to 0.01 It. and velocities were measured at 0.6 of total depth. Distances were messured by stretching a fiberglass measuring tape across the stream and inchoring it at both sides. Distances between haif-way points between each measurement, multiplied by depth. gave a cross-sectional area for each mesurement. These values, multiplied by the velocities, and summed, gave the discharge in $\mathrm{ft}^{3} \mathrm{~s}^{-1}[19.20]$. Preliminary experiments showed that five readings gave difierent results from three readings, so the former number was chosen for greater sccuracy. Standard procedures for velocity readings recommend that no individual section should contain more than $10 \%$ of the total flow, and that $20-30$ separate readings be taken $[19,20]$. These recommendations were followed for early determinations, but were later motitied when it was found that the stage of the river of ten changed appreciably during the course of one series of measurements, which usually trok about one hour. The effect of this change in stage could be reduced by completing the measurements in a shorter time. Data for 8 complete teterminations were reanalyzed, using alternate depth and flow messurements. All abbreviated results were within $13 \%$ of the original values, and 7 were within $4 \%$ of the values (see Table 2, where discharge values are reported as $\mathrm{m}^{3} \mathrm{~min}^{-1}$ ). Since these differences were iess than the error caused by chonges in discharge which usually occurred during the course of a series of measurements, later readings (after July 18) usually invalved $8-10$ sets of measurements and were usually completed within 30 minutes. 
Table 2: Comparison of flow measurements of the Gallinas River using all readings and altemate readings

\begin{tabular}{|c|c|c|c|c|c|}
\hline \multirow[b]{2}{*}{ Date } & \multirow[b]{2}{*}{ Location* } & \multirow{2}{*}{$\begin{array}{l}\text { Number of } \\
\text { readings }\end{array}$} & \multicolumn{2}{|c|}{ Discharge $/ \mathrm{m}^{5} \mathrm{~min}^{-1}$} & \multirow[b]{2}{*}{ Difference/ } \\
\hline & & & All values & Alternate values & \\
\hline $6 / 22$ & $F 2$ & 18 & 32.0 & 28.0 & -13 \\
\hline $6 / 23$ & $F_{2}$ & 17 & 22.1 & 22.0 & -0.5 \\
\hline $6 / 24$ & $\mathrm{~F} 2$ & 17 & 19.9 & 19.9 & 0 \\
\hline $7 / 8$ & 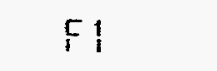 & 24 & 0.408 & 0.414 & $i$ \\
\hline $7 / 12$ & FI & 17 & 0.266 & 0.257 & -3 \\
\hline $7 / 12$ & $F_{4}$ & 20 & 1.25 & 1.24 & -0.6 \\
\hline $7 / 18$ & $F 2$ & 16 & 4.94 & 5.08 & 3 \\
\hline $7 / 18$ & F3 & 14 & 2.67 & 2.76 & 4 \\
\hline
\end{tabular}

\section{Soring Flow Measurements}

Pows from indidus springs were messured with a " 4 quart" plostic bucket which was caiburated by adoing one- or two-dm increments of wister ta the bucket and noting the reading on a scale on the inside of the tucket. The outflow from a spring was collected in the bucket for a specific period of time as measured by a stopwatch. The bucket was placed on a level snot where the volume was read. The bucket was then gently rotated through $160^{\circ}$ to get a second reading which wos combined with the first to obtain an average. This procedure was used to compensate for the surface teing out-of-level. Three readings were usually taken on each occasion. Flow from the "bathouse spring" emerged from a two-inch iron pipe that protruded several $\mathrm{cm}$ above ground level. This spring used to feed the bath house, tut the connection was severed several years ago when the building was locked up because of abuse. A flexibie connector was used to attach the iron pipe to a short length of PVC pipe which was in turn connected to a right-angled elbow and pipe. This allowed the flow ta be collected in the bucket, but in the process the level of water in the reservoir was raised about $20 \mathrm{~cm}$. At "St. Michael's spring" the overflow from the top pool passed through a pipe which allowed easy collection in the bucket. The flow of the "central spring" was occasionally measured in a similar way by collecting the overflow from the lowest bath. 
Eariiest temperaiure readings were obtaineo with a Tayior maximum registering pocket mercury thermometer, with $1^{0} \mathrm{C}$ divisions. Later readings employed a Fluke Madel $51 \mathrm{~K} / \mathrm{J}$ thermometer with $\mathrm{K}$-type bead thermocouple, giving a digital readout to $0.1^{\circ} \mathrm{C}$. Readings at two different temperatures were taken with the Fluke thermometer and a calibrated thermocouple thermometer provided by Los Alamos Hational Laboratory (see Fig. 2). This allowed earlier temperature readings ta be corrected. The Fluke thermometer was then adjusted using an of fset control to give the same reading as the calibrated thermometer at $48^{\circ} \mathrm{C}$. Measurements at different depths in the springs were mode with the maximum reading thermometer.

Figure 2: Comparison of temperature readings of Fluke theriometer against calibrated thernometer

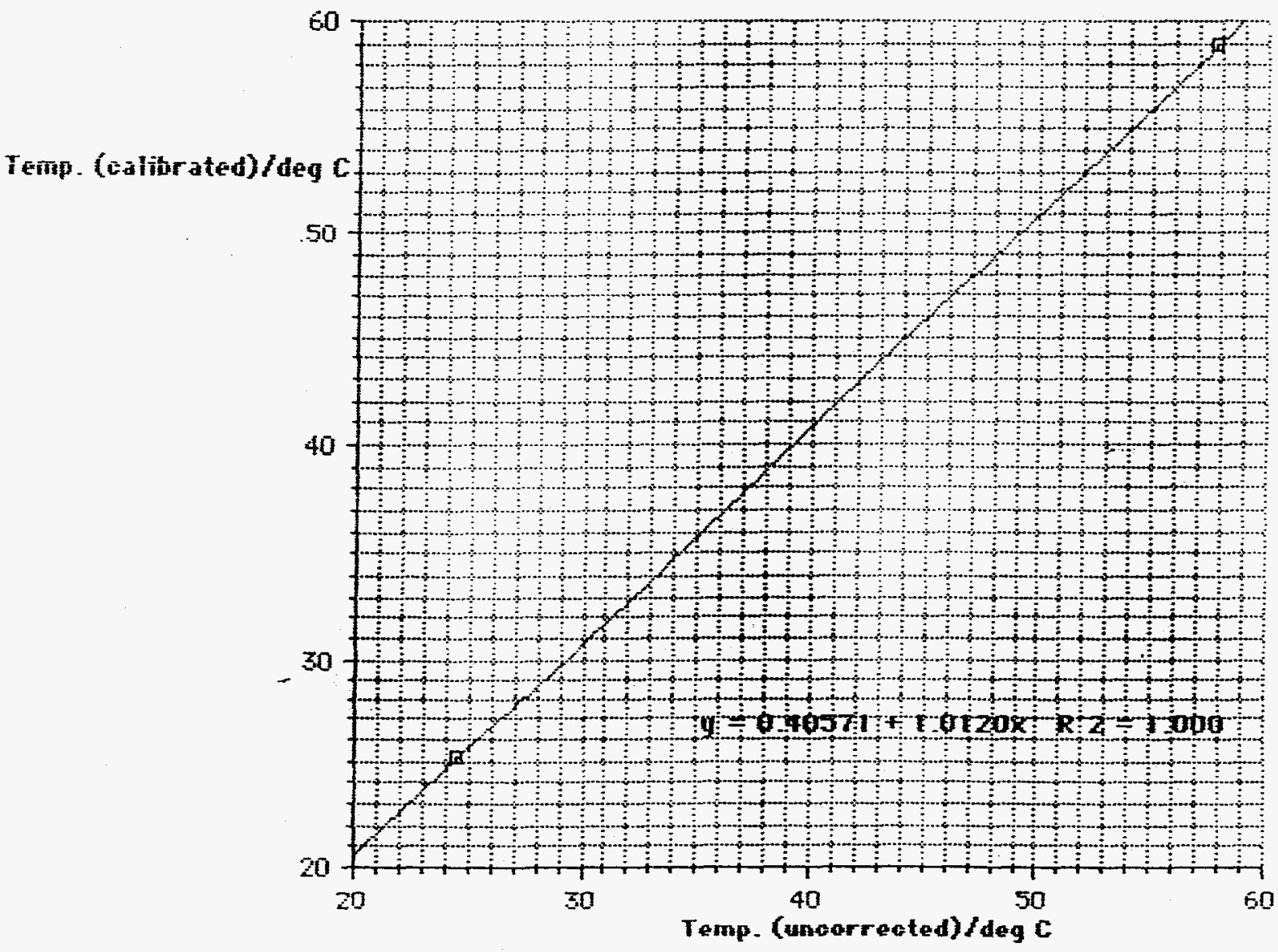




\section{ph Measuirements}

Megsurements of $\mathrm{pH}$ were made in the field with a Hanna Instruments Checker 1 , reading to 0.01 with 0.2 units accuracy. It was standardized against buffers of $\mathrm{pH} 7$ and 10 before its first use, but not at each subsequent use. A later restandardization showed the meter to be reading high, so measurements of $\mathrm{DH}$ recorded in the field are unreliable.

\section{Conductivity Measuraments}

Condurtivity was measured in the field by a Fisher portable conductivity meter Model 152, using intemal standardization and temperature campensation. Camparison with latoratory values abtained at LANL shomed large discrepancies. The instrument was standardized with $000500 \mathrm{MKCl}$ prepared by dissolving $0.373 \mathrm{~g}$ of $\mathrm{KCl}$ in distilled water (specific conductivity = 2 micromha $\mathrm{cm}^{-1}$ ) and diluting to $1 \mathrm{dm}^{3}$ in a volumetric fiask. The instrument was standardized to a value of 717 micromho $\mathrm{cm}^{-1}$ at a temperature of $249^{\circ} \mathrm{C}$. Equivalent conductivity of $000500 \mathrm{M} \mathrm{KCl}=$ $143.48 \times 10^{-4} \mathrm{~m}^{2} 5 \mathrm{~mol}^{-1}=717$ micromhos $\mathrm{cm}^{-1}$ at $250 \mathrm{C}$ [22].) Appreciatle discrepincies were found between row and unfiltered samples of both river and saring woter and between samples at different temperatures as shown in Table 3 .

Table 3: Conductivities of several filtered and unfiltered samples measured at different temperatures

\section{Sample location}

Piver atinve sorinģs

River below powerhouse

Bathhouse spring

Bathhouse spring

\section{Conductivity/micromhos $\mathrm{cm}^{-1}$}

Unfiltered. Filtered Temperature/0 $C$

310

570

1000

855

$$
315
$$

30.2

$54.4 / 41.2$

Thase results indicate that internal temperature compensation is unreliable and that samples must be cooled to approximately $25^{\circ} \mathrm{C}$ before being 
measured. The conductivity changes about $2 \%$ per degree at $25^{\circ} \mathrm{C}[2 \overrightarrow{3}]$. The source of the difference between filtered and unfiltered water is not obvious, especially in the case of the spring water which is so clear that no visible residue is left on the filter even after more than $500 \mathrm{~cm}^{3}$ of water nave been processed. Since riltration is a standard procedure, it is preferable to use that method where fegsible.

\section{Loborgtory Megsuraments}

Water samples were collected in plastic bottles after filtration through a Gelman supor-450 membrane filter supported on a Gelman magnetic filter funnel. Reduced pressure was obtairied with a Nalgene hand-operated wscuum pump. Two $125 \mathrm{~cm}^{3}$ samples were provided for analysis at Los Alamos National Laborstory (LANL); one of the samples was acidified with 10 drops of $70 \%$ nitric acid. For analysis in the United world College (UWC) latorataries, $500 \mathrm{~cm}^{3}$ samples were collected in glass tot tles. Two 500 $\mathrm{cm}^{3}$ samples of raw water were collected for tritium analysis.

Analyses performed at LANL an samples taken from the hot springs and nver are those described tij Trujillo et al. [24]. Analyses undertaken so far in the UwC latoratories have been for chloride and diseolved asygen. Most chloride analyses used a Hach digital titrator with a $2.256 \mathrm{~N} \mathrm{Hg}\left(\mathrm{NO}_{3}\right)_{2}$ cartridge and diphenylcortiazone as indicator. Samples of $100 \mathrm{~cm}^{3}$ were titrated according to instructions provided with the kit [25].

Argentometric titrations were also caried out using procedures recommended in Stondord tathods [26]. Silver nitrate solution 0.0250 mol $\mathrm{dm}^{-3}$ ) was prepared by dissolving and diluting $0.425 \mathrm{~g}$ Fisher ACS certified $\mathrm{AgNO}$, with distilled water to $1000 \mathrm{~cm}^{3}$ in a volumetric flask. The solution was stared in a brown bottle. Potassium chromote indicator solution was prepared ty discolving $50 \mathrm{~g}$ of $\mathrm{K}_{2} \mathrm{CrO}_{4}$ (Flinn Scientific, $99.0 \%$ minimum) in distilled water, adding AgNO 3 solution until a visible red precipitate was formed, sllowing the mixture to stand for 12 hours, filtering, and diluting to $1000 \mathrm{~cm}^{3}$ with distilled woter. The titrations were corried out on $50 \mathrm{~cm}^{3}$ samples (or smaller portions diluted to $50 \mathrm{~cm}^{3}$ ) to which $1 \mathrm{~cm}^{3}$ of indicator solution was added. Instructions recommend that solutions be adjusted to $\mathrm{pH}=7-10$ teiore titration. This was not necessary for spring samples, which already were within this range. A visual camparison was made by 

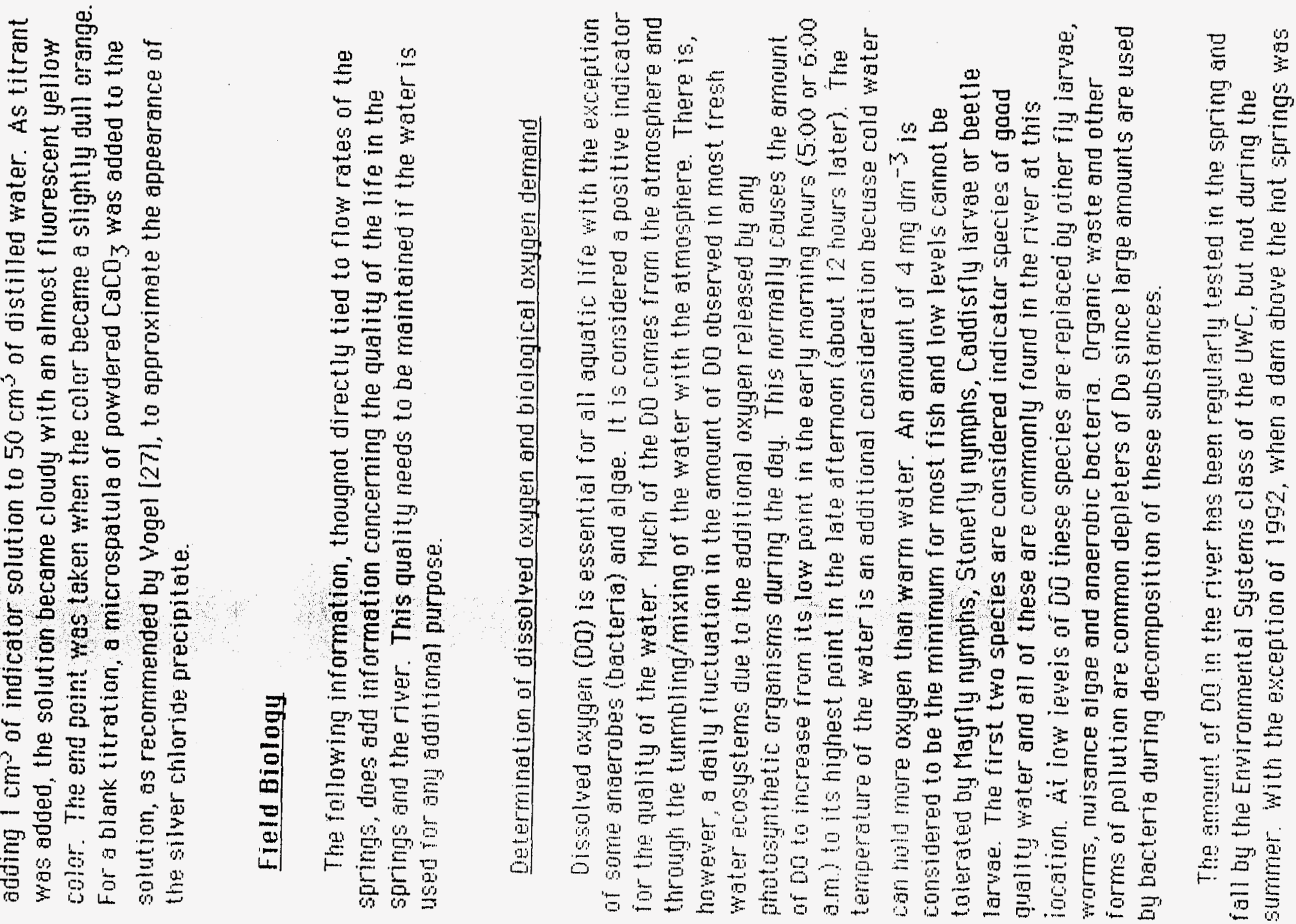
bresched ond the outflow of silt smothered virtuslly oll the organisms in this stretch of the river, the DO in the river has been far above any denger point ( 8 ta $9 \mathrm{mg} \mathrm{dm}^{-3}$ ). The hot springs have not been routinely tested. The presence of $D 0$ in the hot springs is of concern, not because of any large organisms living there, but because anaerobic conditions and the algae and bacteria that would live in them wiguld give the water and the area an unpleasant odor and appearance.

A preliminary check of the bo in the river above and below the hot springs and in one of the batrs (immediately east of *3, Figure 1)was carried out on July 19, 1994. This was done between 8:00 and 9:30 a.m. and again between 4:00 and 5:30 p.mn. using a small Lalyotte test kit. Two samples were tested at each of two river sites (F2 and $F 3$ ); one from the flowing portion of the river and one from s relatively slow moving ares. Later determinations were performed with an axygen electrode (orion hadel 97-08) connected to a digital pH meter (orion Model 221). At this time an additional somple was taken from the river atout halfway through the hot springs discharge area (telow *19, Figure 1).

Water somples collected on ding 19 from the same sites as used for bo were tested for total Coliform and $E \mathrm{Ch}$. Samples of $100 \mathrm{~cm}^{3}$ from each site were filtered and incubsted on the aporonriste media (MFC and Endo) for 24 hours

\section{Plant and glgae species}

On duly 20 and during the following month collections of algae and plants were made to determine the common species found in the river and in the hot springs.

\section{RESULTS}

\section{Stage Measurements}

In Table 4 are shown ali data concerning river stage measurements at two points above the springs: location $F 2$ and the gauge. F1gure 3 shows points where megsurements were taken at both locotions; this allows measurements at location $F 2$, which can be taken quickly, to be converted to measurements at the gauge, which can be used for long-term measurements. 
Measurements at the two points could nat be taken simultaneously, but were separated by two to ten minutes. On July 21 a number of flow and stage measurements were made, including times when the stage changed as much as $0.1 \mathrm{~cm}$ per minute. A plot of these measurements at lacation $F 2$ is given in Figure 4. From this graph are taken values for readings at location F2 corresponding to the times when readings were taken at the gouge. These interpolated values are included in column 6 of Table 4 as corrected readings and used as points in Figure 3 . 


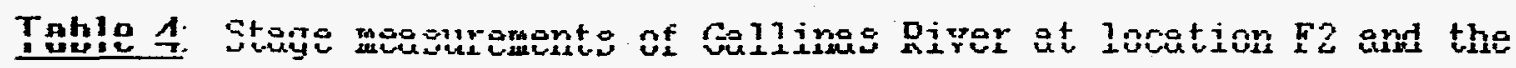
gauge.

Lucation F2

Qote Time $/ \mathrm{hr}:$ min Regding/ $/ \mathrm{cm}$ Corrected $1 / \mathrm{cm}$

$\begin{array}{llr}6 / 24 / 94 & 12: 00 & 9.9 \\ & 13: 30 & 10.0 \\ 6 / 27 / 94 & 15: 00 & 11.4 \\ & 16: 30 & 6.2 \\ 6 / 28 / 94 & 11: 40 & -2.8 \\ 7 / 1 / 94 & 11: 15 & -4.9 \\ & 15: 00 & -4.9 \\ 7 / 9 / 94 & 10: 00 & -5.7 \\ & 12: 20 & -6.0 \\ 7 / 1 / 194 & & -5.2 \\ 7 / 12 / 94 & 09: 15 & -6.7\end{array}$

$1640-7.3$

$713794 \quad 16: 45 \quad-4.2$

$716.94 \quad 13: 10 \quad 3.8$

$14: 15 \quad-0.4$

$7 / 19 / 94 \quad 09.55 \quad-4.8$

$14.50 \quad-5.6$

$16: 00 \quad-5.6$

$17: 15 \quad-5.6$

$18: 15 \quad-5.6$

$19.05 \quad-5.7$

$721 / 94 \quad 0925 \quad 90$

10:01 7.6

$10: 32 \quad 6.8$

$10: 39 \quad 6.7$

$11: 12 \quad 6.2$

$12.50 \quad 5.2$

$13: 00 \quad 4 . \overline{6}$

$13.40 \quad 4.4$
Gavge

Time/hr:min Readina/cm

$\begin{array}{llll}9.9 & & & \\ .0 & & & \\ .4 & & & \\ .8 & & & \\ 4.9 & -4.9 & 11: 15 & 19.7 \\ 4.9 & -4.9 & 15: 10 & 19.5 \\ .7 & -5.7 & 10: 10 & 16.7 \\ .0 & -6.0 & 12: 15 & 16.3 \\ .2 & & & \\ .7 & -6.7 & 09.30 & 17.8 \\ & & 11.20 & 17.6\end{array}$


Iahle 1. Stoige mesurements of Gullings River ut location F2 and the gauge.

Lacation F2

Dote Time/hr:min Reading $/ \mathrm{cm}$ Corrected $1 / \mathrm{cm}$

$6 / 24 / 94$

$12: 00$

$13: 30$

9.9

10.0

$6 / 27 / 94$

$15: 00$

$16: 30$

$6 / 28 / 94 \quad 11: 40$

71194

$11: 15$

15:00

$7 / 9 / 94$

$10: 00$

$12: 20$

711194

712194

09.15

$16: 40$

$713794 \quad 16: 45$

$7 / 16 / 94$

$13: 10$

14:15

$7 / 19,94$

09.55

14.50

16:00

$17: 15$

$10: 15$

19.05

712194

$09: 25$

$10: 01$

$10: 32$

$10: 39$

$11: 12$

12:50

13:00

$13: 40$
11.4

6.2

$-2.8$

$-4.9$

$-4.9$

$-5.7$

$-6.0$

$-5.2$

$-6.7$

$-4.9$

$-4.9$

$-5.7$

$-6.0$

$-6.7$

$09: 30$

$11: 20$

17.8

$17 \%$
Gauqe

Time/hr:min Reouling/em
$-7.3$

$-4.2$

3.6

$-0.4$

$-4.5$

$-5.6$

$-5.6$

$-5.5$

$-5.6$

$-5.7$

90

7.6

6.8

6.7

6.2

5.2

5.0

$12: 55$

31.5 
Table 4, continued

Location F2

Qgte Time/hr:min Reading $/ \mathrm{cm}$ Corrected $1 / \mathrm{cm}$

$721 / 94 \quad 13: 50$

15:00

$725 / 94$

726.94

13:55

$09: 30$

10:04

10:41

10.52

$7 / 31 / 94$

$06: 25$

11:25

$11: 54$

$12: 01$

12.40

13.58

$51 / 94$

$09: 05$

$12: 02$

$16: 25$

$8 / 5 / 94$

$14: 30$

$14: 45$

3/8/94

$8 / 9 / 94$

$15: 13$

$09: 15$

$14: 45$

$8 / 11 / 94$
2.8

$-2.4$

$-5.0$

8.3

8.1

7.8

7.8

15.0

4.8

4.7

4.6

4.3

4.2

6.0

4.2

3.2

13.7

13.0

8.7

8.2

7.8

7.3

6.6
2.9

$-2.9$

$-5.0$

6.1

7.8

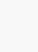

4.2

Gauge

Time/hr:min Readina/cm

$13: 46$

20.9

15:05

22.3

$14: 00$

18.9

09.58

35.7

$10: 49 \quad 35.2$

$14: 15$

6.6

$11: 59$

30.8

$12: 46$

30.5

1 $3: 53$

30.4

(1) For each reading at the gauge. a "corrected" ralue at location F2 is given. This corrected value is either a reading taken at approximatel 7 the salue time at location $F 2$, or a value interpolated from Figure 4 to correspond to the sane time as the gauge reading. 
Figure 3: Plat of corrected stage readings at location $F 2$ against gauge readings

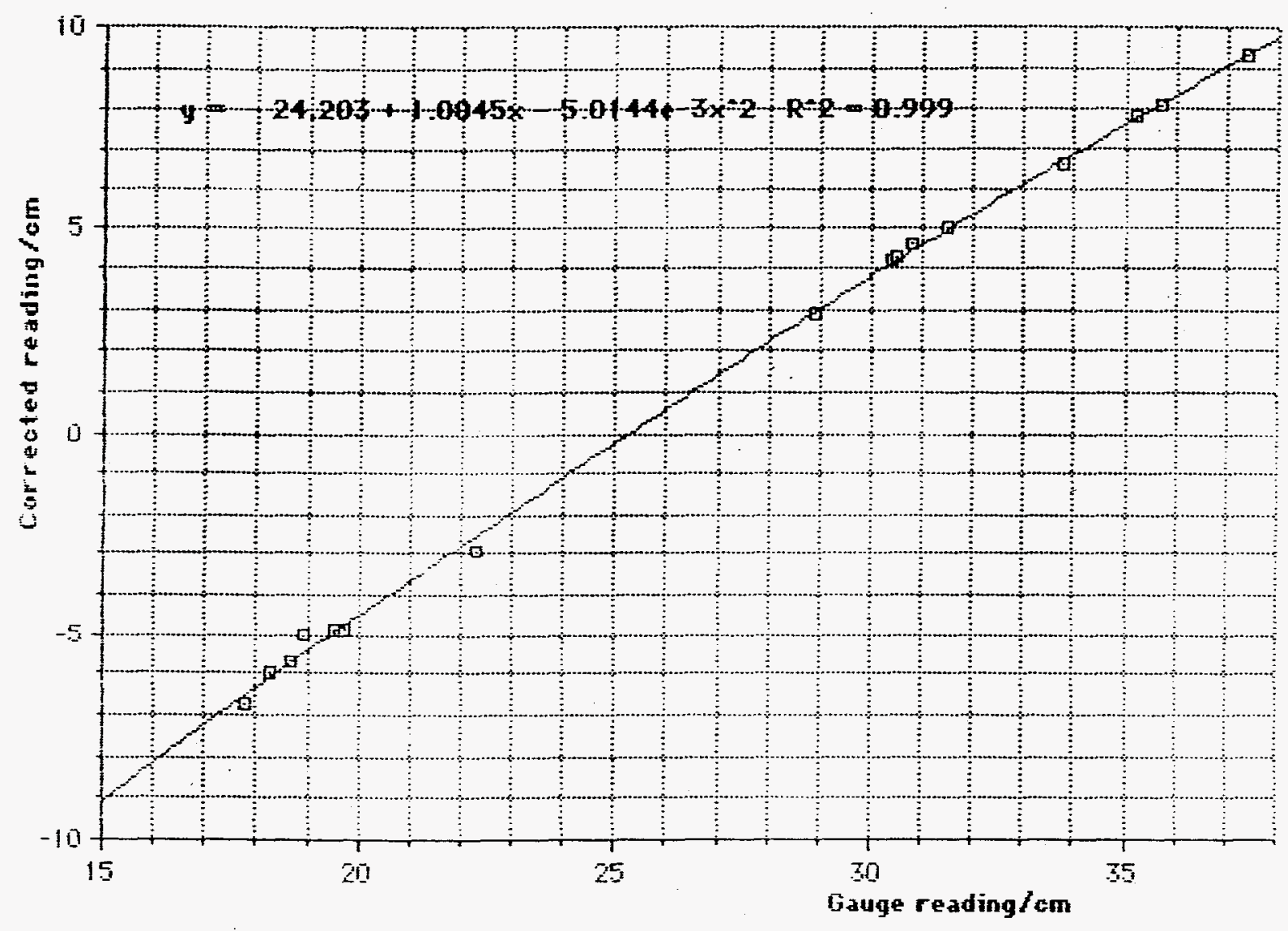




\section{Figure 4. Plot of stage readings at location F2 on July 21, 1994}

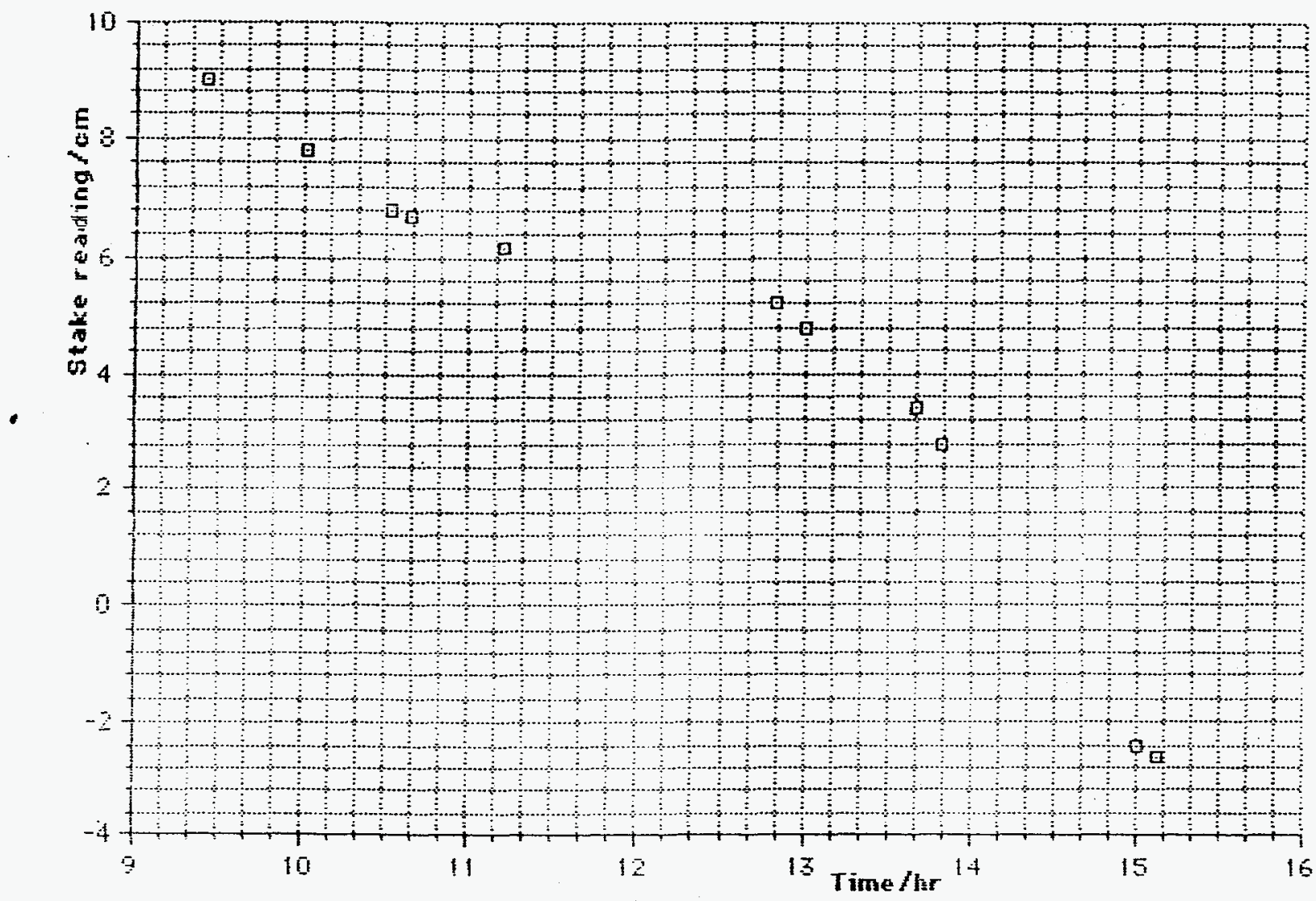

\section{River Fiow heasurements}

Datio for thow measurements are given in Table 5 , grouped according to the location where the measurements were made, ond arranged in chronoligical order within each group. The stage is that measured at the gauge, and the discharge, calculated according to equation 1, is reported as $\mathrm{m}^{3} \mathrm{~min}^{-1}$. The cross-sectional areas are summed for each set of measurements and reported as Ares. The product of Area and Average velocity (column 7) provides another measure of discharge. which is given in column $a$. To svoid distortion of the suerage velocity values, data for sections contributing less than 1 s to the total flow are omitted from the calculations in column 6 . In column 9 , column 7 is divided by column 4 to cumpare these two messures af discharge. Graphs of discharge (column 4) ve stage are given for each of the three main measurement lacations in 
Figures 5-7. The data show good fit to second-order, or parabolic, relationships. Results for the two sites above the springs (locations Fl and F2) in Table 5 might have been combined, but there is insufficient overlap in the dato to give confidence that theij belong tó a single set. As a test of possible errors in the discharge data, cross-sectional areas and average velocities are plotted against stage at each location (Figures $8-13$ ), and like discharge measures, should fall on smooth second-order curves.

Several dato were collected at sites F1 and F3 in 1995 in hopes of obtaining more reliable curves. The second messurement at $F 1$ in 1995 was taken about eight meters upstream from the lacation where other measurements were taken, to check for consistency. Combining dato from different years involves the risk that the stream bed may have changed. giving a different relationship between stage and discharge. The new data from $F /$ were included in the graphs because a reasonable curve falls close 10 all points. bata for $F 3$ from 1995 were excluded because their internal consistency (column 7 divided by column 4 ) is relatively low. 
Finure 5: plot of river discharge vo stage at location F1 above springs (low flow)

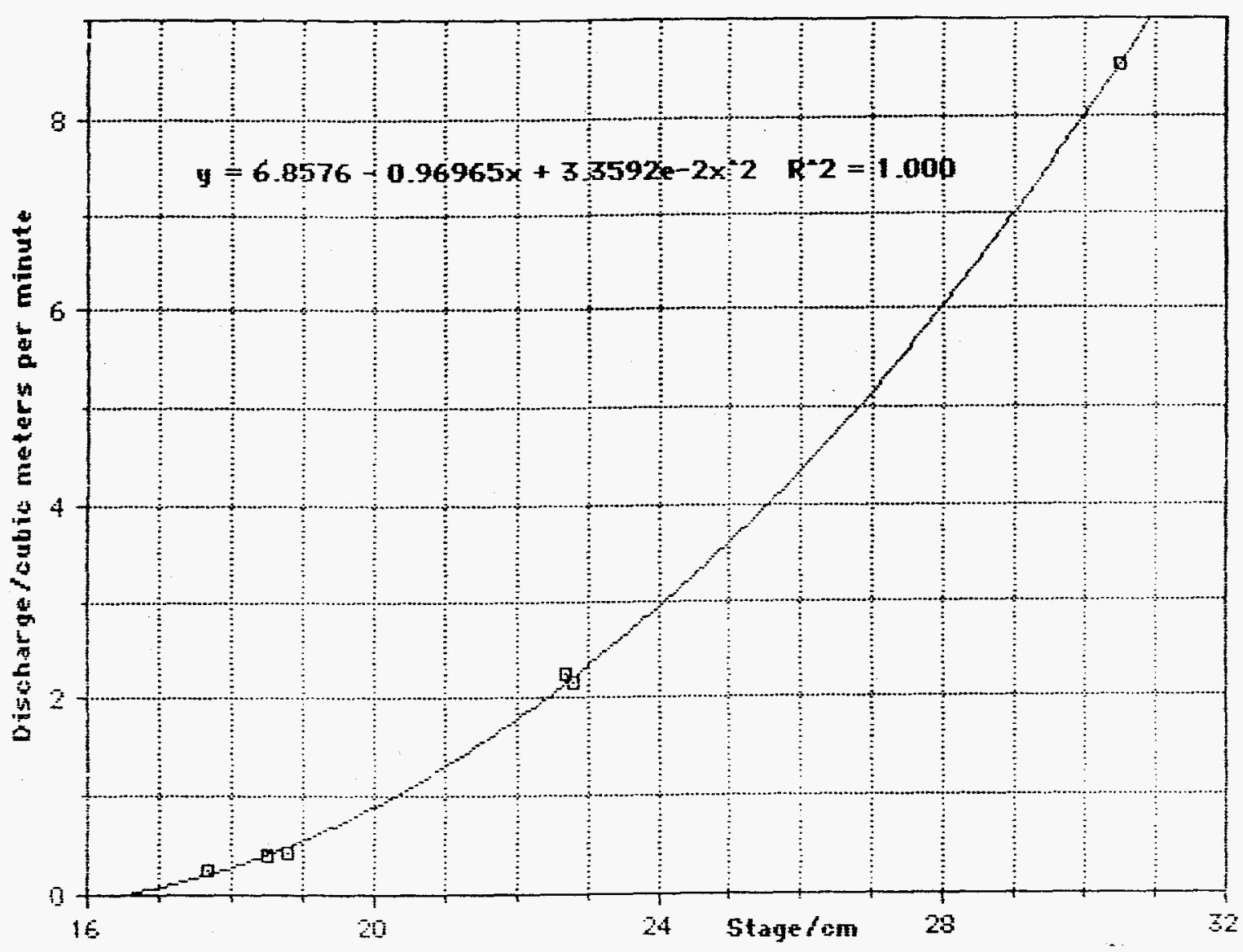


Figure 6: plot of river discharge v3 stage at location F2, above springs (high flow)

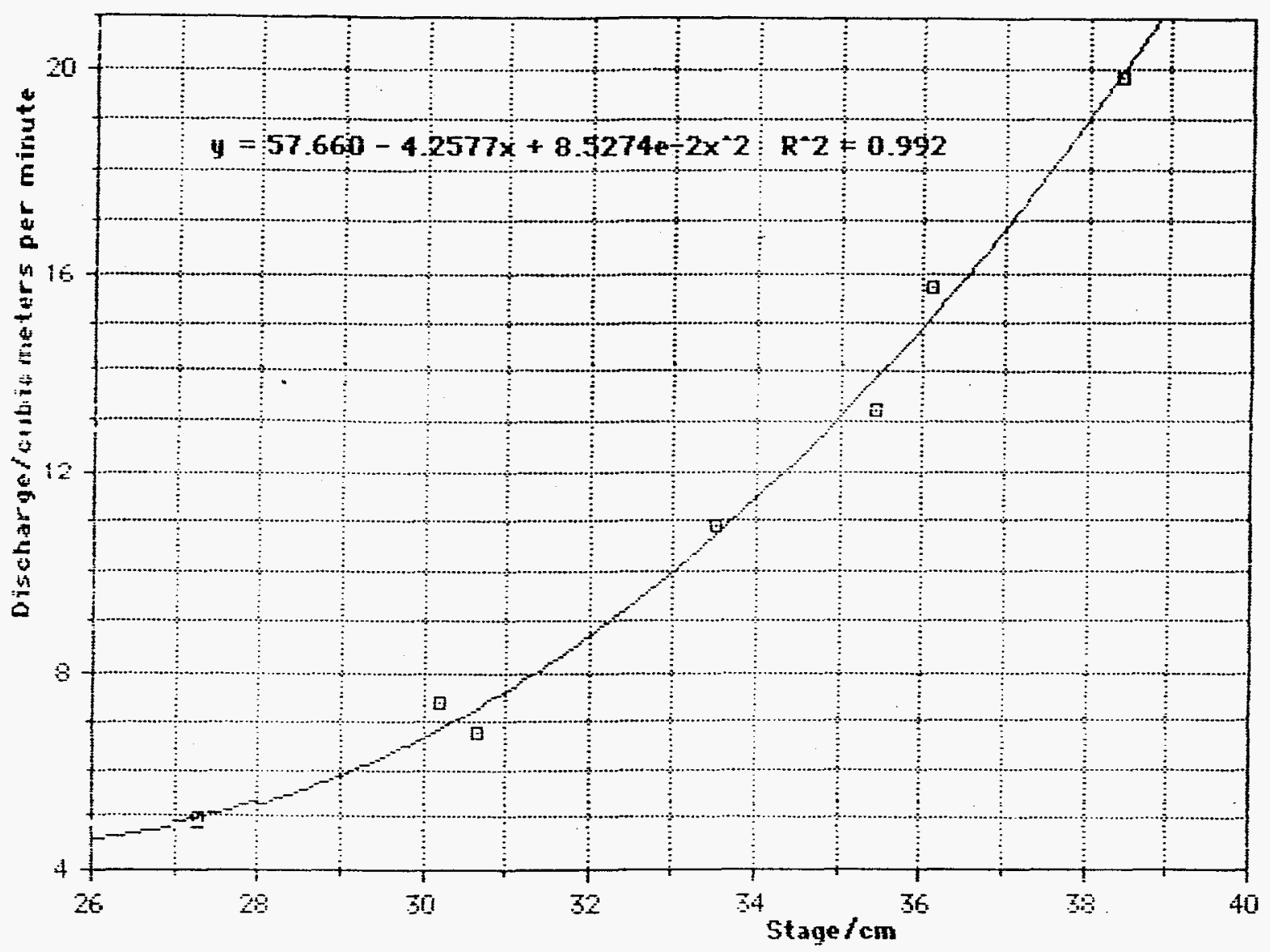




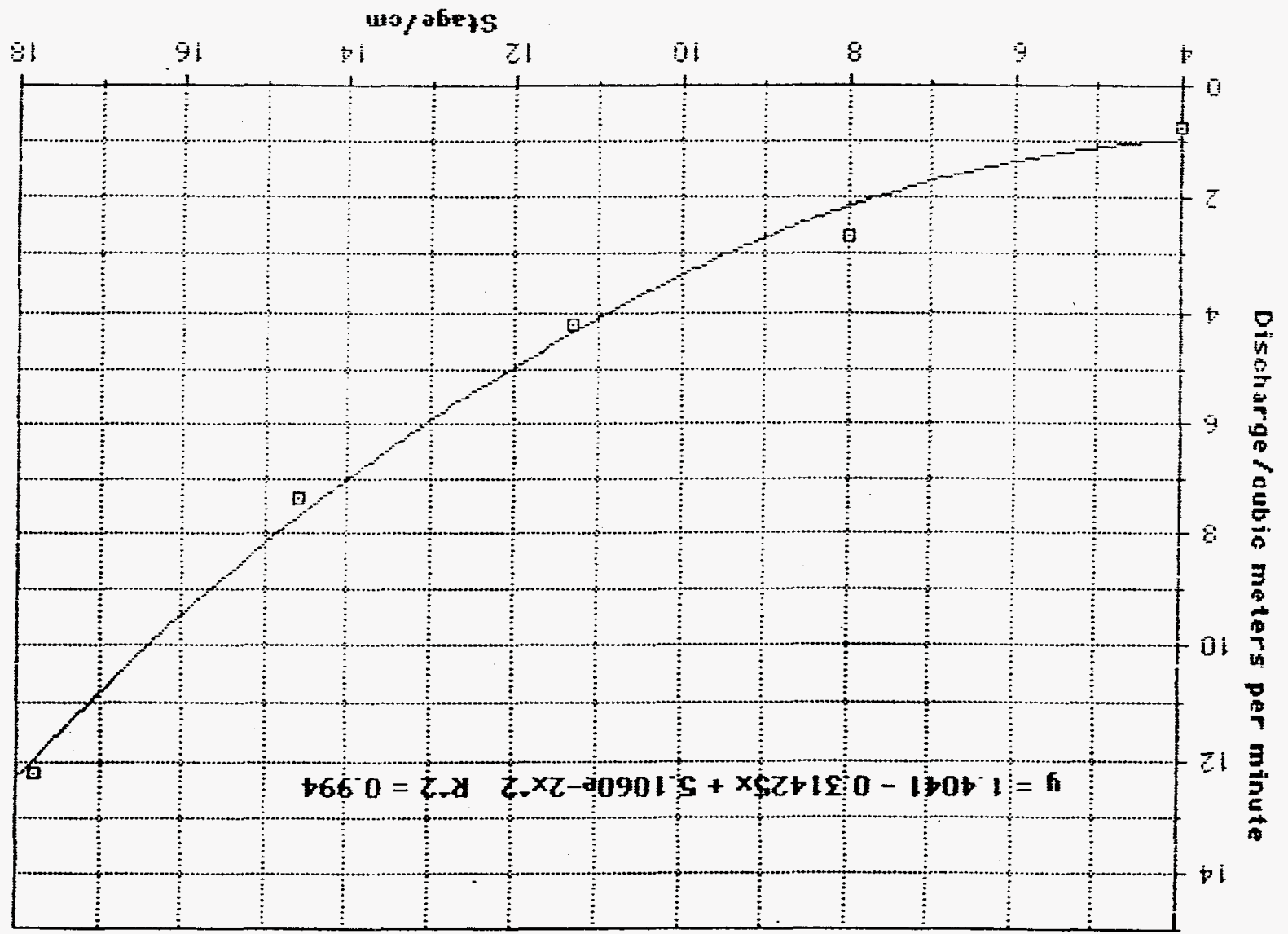

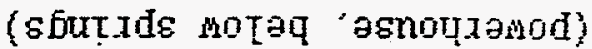

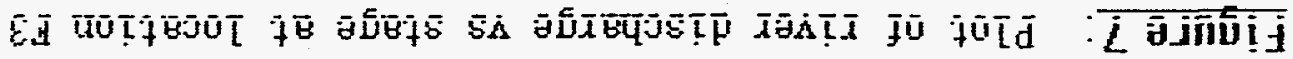




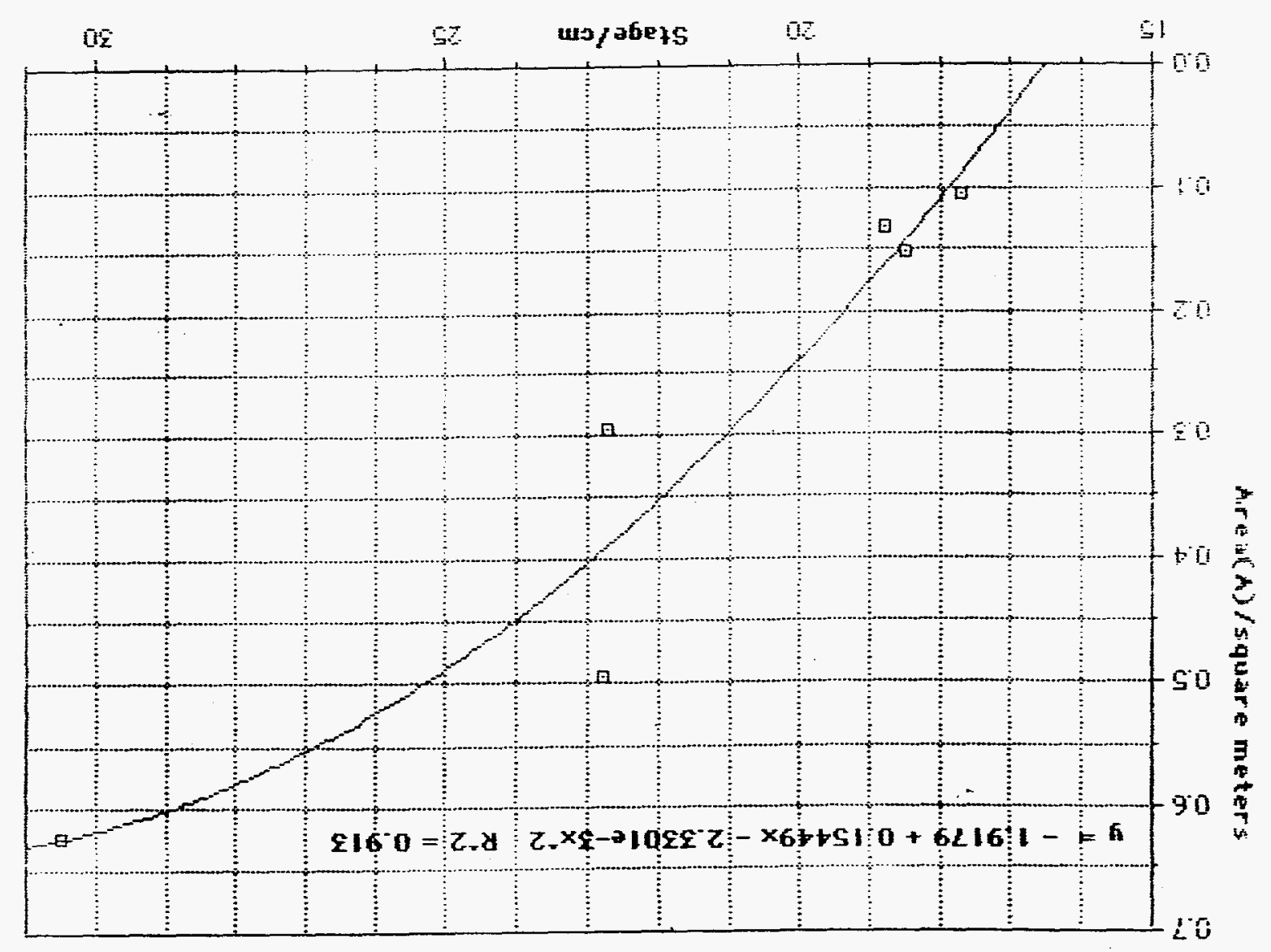

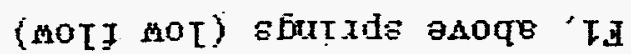

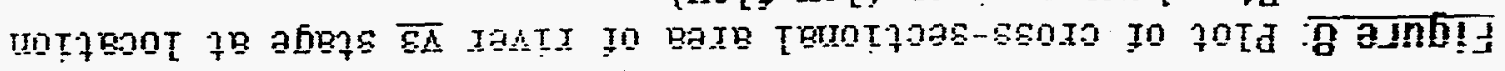


Figure 9: Plot of average velocity of river flow $\mathbf{q 3}$ stage at location $\mathrm{F} 1$, above springs (low flow)

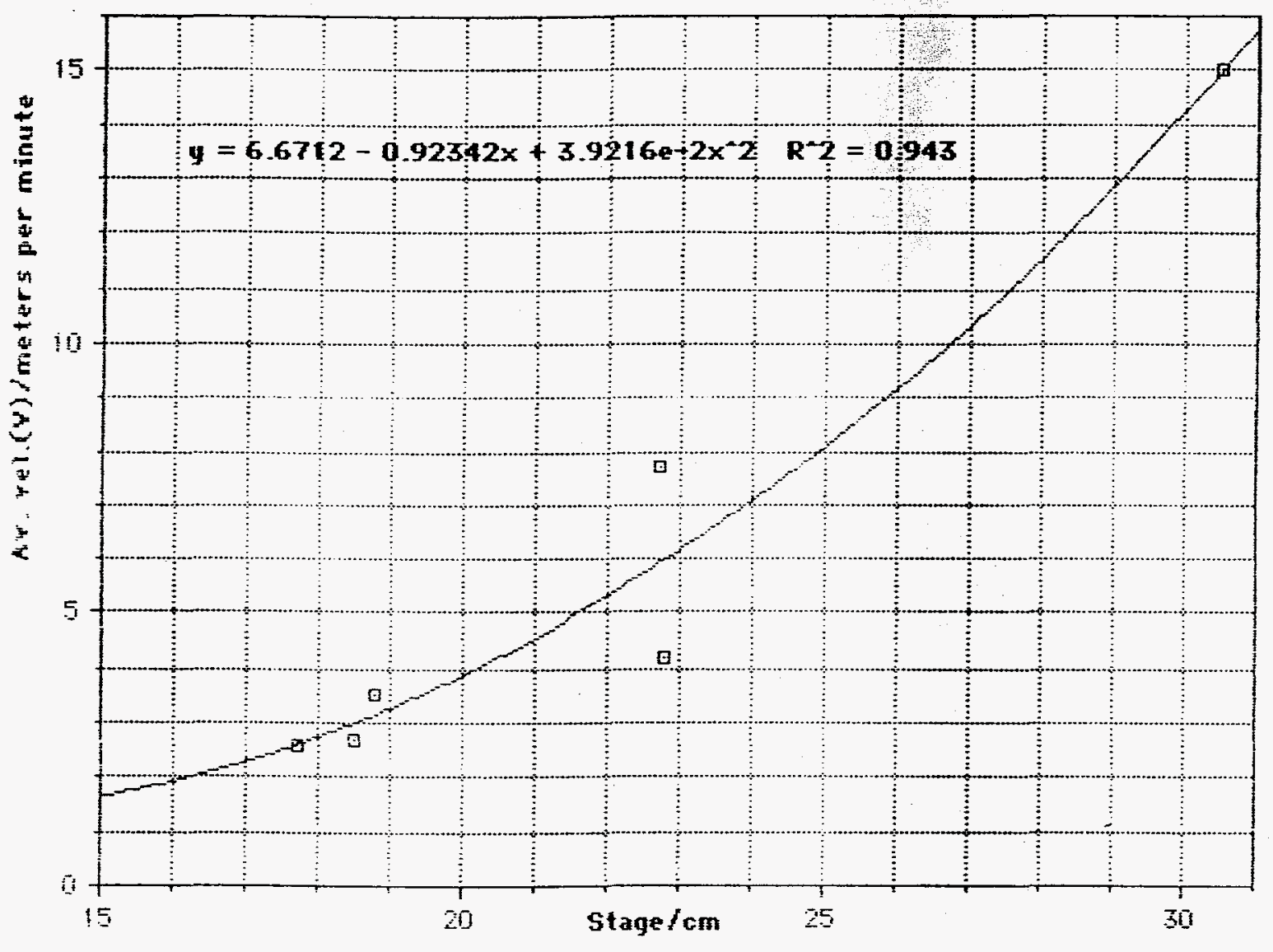


Figure 10: Plot of cross-sectional area of river vs stage at location F2, above springs (high flow)

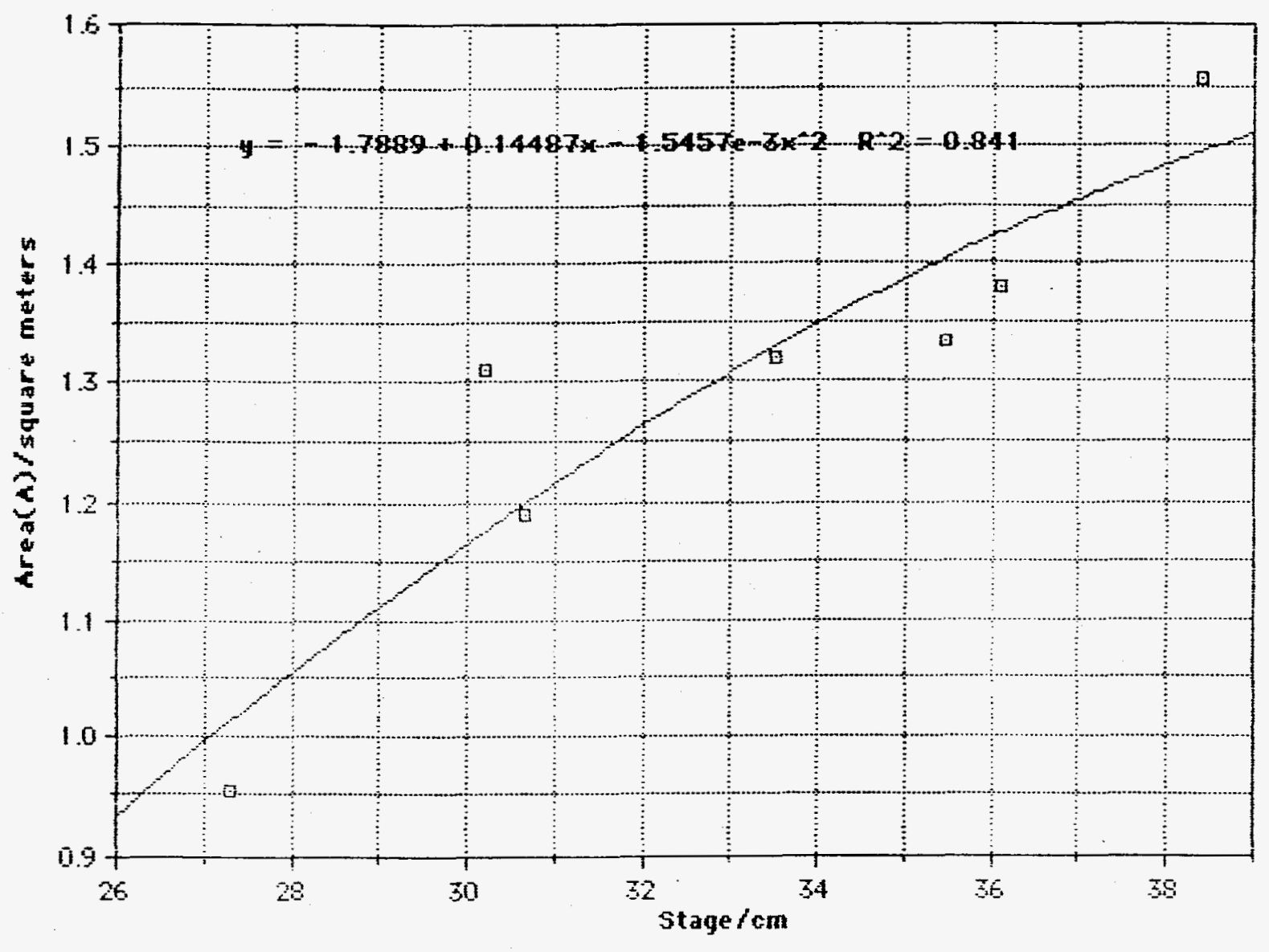


Figure 11: Plot of average velocity of river flon ws stage at location F2, above springs (high flow)

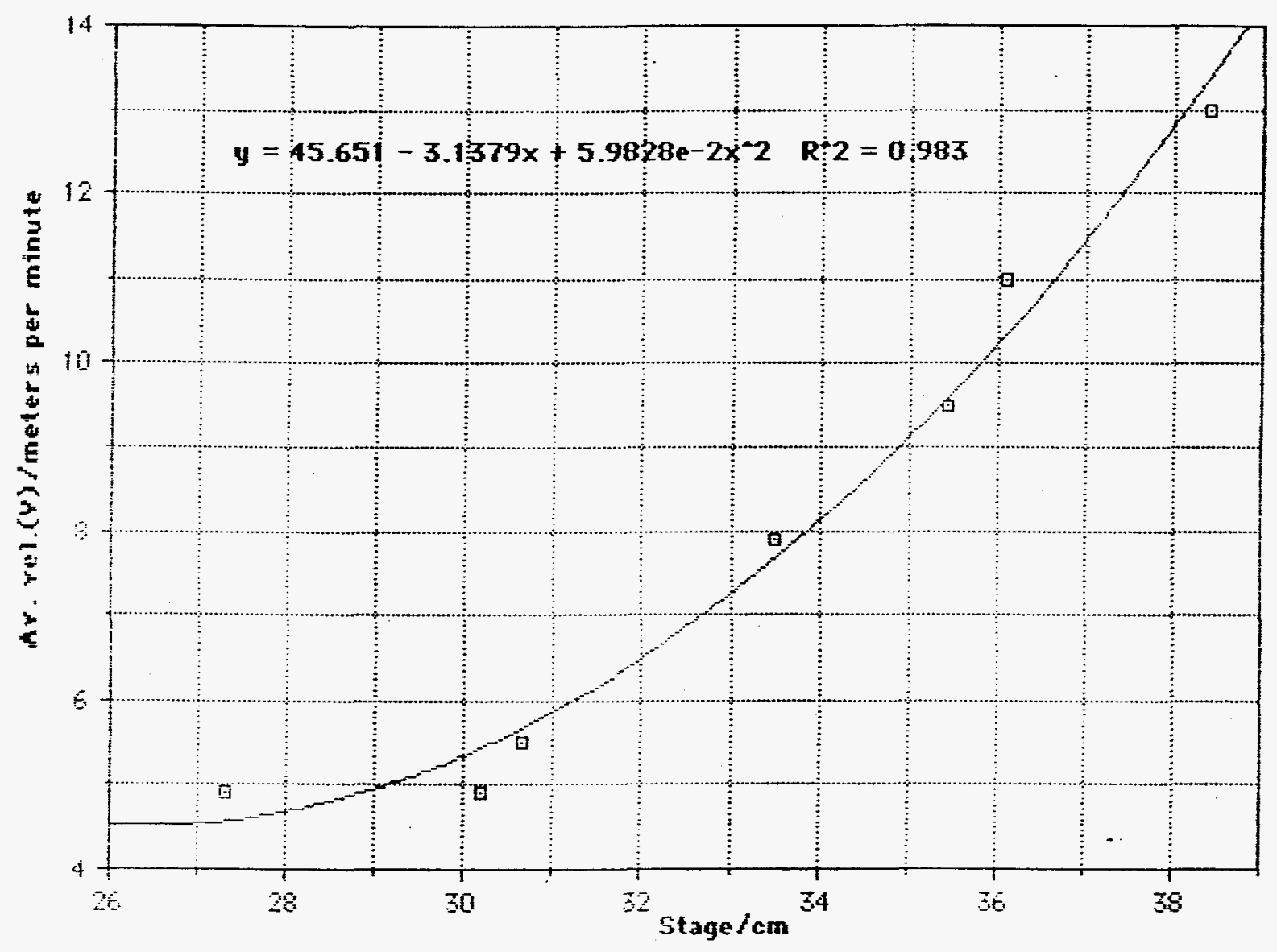


Figure 12: plot of cross-sectional area of river ys stage at location F3 (below springs)

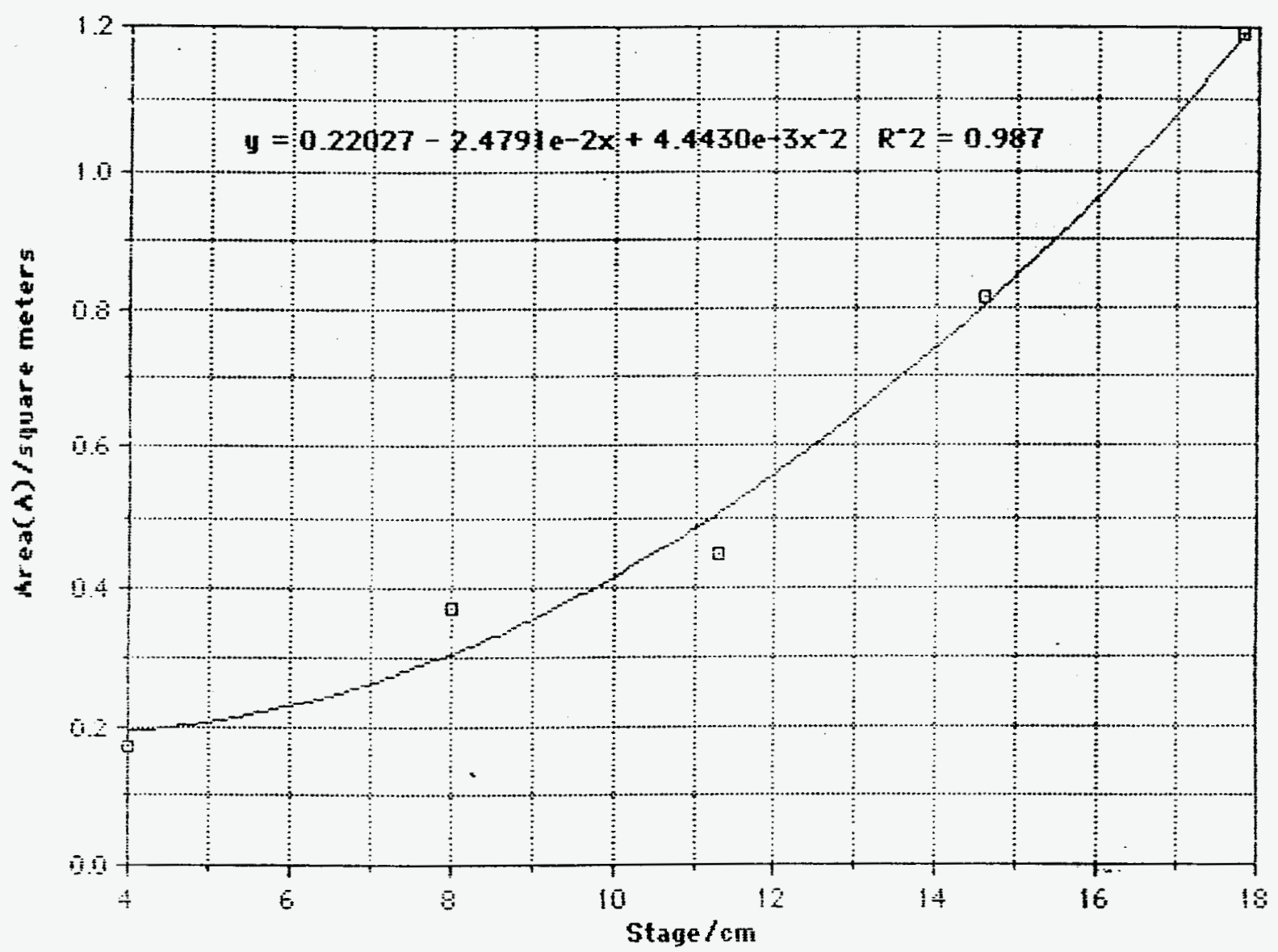


Figure 13: Plot of averange velocity of river flow vs stage at location $\mathrm{F} 3$ (below springs

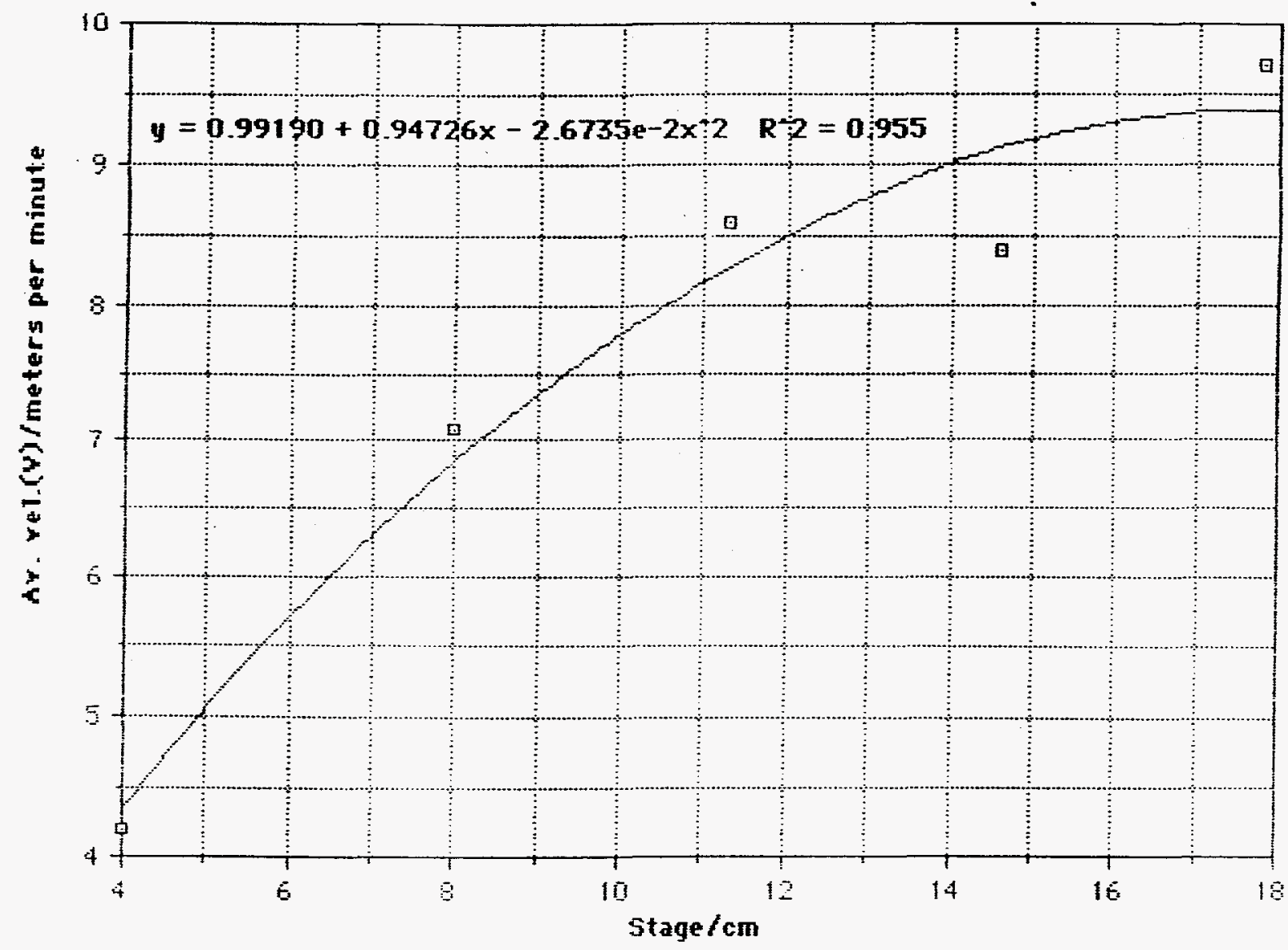

\section{Spring Flpw Magurements}

Measurements of flow and temperature were taken for the bathouse soring (* 1 in Figure 1) and for St. Michael's soring (*13 in Figure 1) from $7 / 1 / 94$ to $6 / 2 / 95$. Air temperatures and atmospheric pressures were messured from 10/94. These data are recorded in Table 6 . Flow and temperature readings were taken also for the central spring (*6 in Figure 1) on several nccasions. The flow ranged from 14.2 to $16.3 \mathrm{dm}^{3} \mathrm{~min}^{-1}$ and the temperature from 53.7 to $55.50 \mathrm{C}$. Discharges and temperatures for the tathhouse and St. Michael's spring are plotted against time in Figures 14 and 15. Figure 16 compares the flow of the bathouse spring with atmospheric pressure and Figure 17 compares the temperature of the spring with the tempergture of the air. 
Table 6: Discharge and tenperature readings for various springs

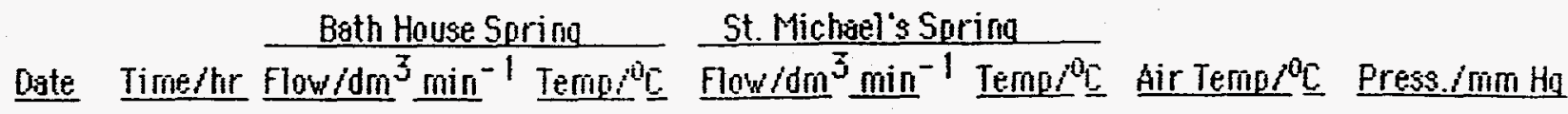

\begin{tabular}{|c|c|c|c|c|c|}
\hline \multirow{3}{*}{$\begin{array}{l}7 / 1 / 94 \\
7 / 5 / 94\end{array}$} & 19 & 40.2 & & & \\
\hline & 10 & & & 14.0 & \\
\hline & 12 & 39.1 & & 14.0 & \\
\hline \multirow[t]{2}{*}{$7 / 9 / 94$} & 10 & & & 14.0 & \\
\hline & 14 & 41.6 & 54.4 & 14.4 & \\
\hline $712: 94$ & 13 & 40.6 & 54.5 & 14.0 & \\
\hline 711394 & 16 & & 54.0 & & \\
\hline \multirow{2}{*}{$7 / 19 / 94$} & 14 & 39.9 & & 11.8 & \\
\hline & 20 & & 54.3 & & \\
\hline $7 / 25 / 94$ & 17 & 41.4 & & 13.7 & \\
\hline \multirow[t]{2}{*}{$7 / 29 / 94$} & 12 & & & 15.2 & \\
\hline & 16 & 43.3 & & & \\
\hline $7 / 30 / 94$ & 11 & 43.7 & 540 & 14.8 & 47.6 \\
\hline \multirow[t]{2}{*}{$7 / 31 / 94$} & 10 & & & 14.4 & 47.7 \\
\hline & 21 & 43.7 & 543 & & \\
\hline $8 / 104$ & 12 & 43.3 & 540 & 14.8 & 47.6 \\
\hline \multirow[t]{2}{*}{$8 / 3 / 94$} & 12 & & & 15.2 & 48.9 \\
\hline & 14 & 448 & 54.3 & & \\
\hline $8 / 4 / 94$ & 14 & 44.8 & 545 & & \\
\hline \multirow[t]{3}{*}{$3 / 5 / 94$} & 10 & & & 14.8 & 47.5 \\
\hline & 11 & 39.5 & 541 & & \\
\hline & 16 & 44.8 & 54.3 & & \\
\hline $3 / 6_{0} / 94$ & 11 & 44.8 & 540 & & \\
\hline $8 / 9 / 94$ & 09 & 44.0 & 54.4 & & \\
\hline $8 / 11 / 94$ & 10 & & & 144 & 47.9 \\
\hline \multirow[t]{2}{*}{$0 / 12 / 94$} & 11 & 47.5 & 54.3 & 148 & 47.7 \\
\hline & 17 & 440 & 54.1 & 15.2 & 46.7 \\
\hline $8 / 13 / 94$ & 17 & 437 & 546 & & \\
\hline \multirow{2}{*}{$8 / 14 / 94$} & 09 & 45.7 & 54.5 & & \\
\hline & 16 & 440 & 54.9 & 11.8 & 48.4 \\
\hline \multirow[t]{2}{*}{$6 / 15 / 94$} & 08 & 440 & 54.7 & & \\
\hline & 16 & 444 & 546 & & \\
\hline \multirow[t]{2}{*}{$8 / 16 / 94$} & 08 & 440 & 546 & 13.3 & 47.4 \\
\hline & 18 & 44.0 & 54.6 & 13.7 & 48.6 \\
\hline $3 / 17 / 94$ & 16 & $44 \pi$ & 54.4 & 13.3 & 48.4 \\
\hline $5 / 18 / 94$ & 17 & 43.7 & 54.3 & & 48.1 \\
\hline $8 / 19 / 94$ & 08 & 43.7 & 545 & 13.7 & 47.2 \\
\hline $8 / 20 / 94$ & 20 & 43.7 & 54.7 & 14.4 & 48.0 \\
\hline $8 / 21 / 94$ & 09 & 43.7 & 54.7 & 14.8 & 47.7 \\
\hline $8 / 22 / 94$ & 20 & 47.8 & 54.7 & 14.4 & 47.9 \\
\hline $3 / 25 / 94$ & 18 & 43.7 & 54.7 & & 47.9 \\
\hline $8 / 26 / 94$ & $0 \mathrm{~s}$ & & & 14.8 & 47.3 \\
\hline $9 / 1 / 94$ & 10 & 448 & 54.5 & 156 & 48.1 \\
\hline $9 / 4 / 94$ & 10 & 45.2 & 54.6 & 156 & 47.9 \\
\hline $\bar{y} / 7 / 94$ & 10 & & 54.1 & 15.7 & 47.6 \\
\hline $9 / 11 / 94$ & 04 & 45.2 & 54.1 & 13.5 & 40.3 \\
\hline
\end{tabular}


Table 6: Continued

Bath House Saring

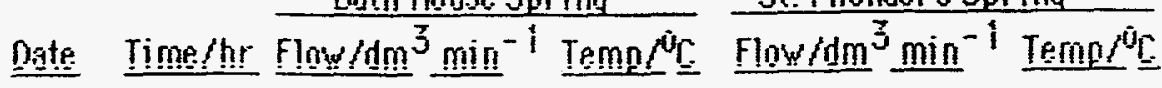

\begin{tabular}{|c|c|c|}
\hline $9: 14: 94$ & 09 & 45.5 \\
\hline & 18 & \\
\hline $9 / 18 / 94$ & 14 & 43.9 \\
\hline $9: 21 / 94$ & 19 & 64. \\
\hline 9122194 & 18 & 46 \\
\hline $9 / 24 / 94$ & 10 & $0 . t$ \\
\hline 9129194 & 18 & \\
\hline 101394 & 09 & $44 t$ \\
\hline $10 / 8 / 94$ & 09 & $45 . t$ \\
\hline $10 / 12 / 94$ & 10 & 45.1 \\
\hline $10 / 22 / 94$ & 12 & 46. \\
\hline $10 / 23 / 94$ & 18 & 46. \\
\hline 1012944 & 10 & 45 \\
\hline & 17 & 45 \\
\hline $10 / 30 / 94$ & 08 & 44. \\
\hline & $1 \neq$ & \\
\hline & 17 & 44.8 \\
\hline 103994 & 09 & \\
\hline & 17 & 45 \\
\hline 111194 & 09 & \\
\hline & 16 & \\
\hline 112794 & 19 & 44 \\
\hline & 17 & \\
\hline 111994 & $b 0$ & \\
\hline & 17 & 45.1 \\
\hline 111494 & 14 & \\
\hline $11: 5: 94$ & 98 & 45. \\
\hline $11: 10,94$ & 10 & 46. \\
\hline $11: 1284$ & 13 & 47. \\
\hline 1119094 & 19 & 46 \\
\hline 1111494 & 09 & 46. \\
\hline & 15 & \\
\hline 1111 & 09 & 46.1 \\
\hline $11: 23194$ & 10 & 45 \\
\hline $11: 24: 94$ & 13 & 45 \\
\hline $11 / 26 / 94$ & 15 & $4 c$ \\
\hline $11 / 30 / 94$ & 13 & 45 \\
\hline 1213194 & 11 & \\
\hline & 12 & 44.6 \\
\hline 126994 & 15 & $4=$ \\
\hline $12 / 16 / 94$ & 12 & 4 \\
\hline $12 / 19 / 94$ & 13 & 4 \\
\hline 12127194 & 16 & 4 \\
\hline $1 / 2 / 95$ & 16 & \\
\hline $1 / 11 / 95$ & 09 & \\
\hline $1 / 15 / 95$ & 10 & \\
\hline $1 / 29 / 95$ & 14 & \\
\hline
\end{tabular}

$\begin{array}{ll}54.7 & 14.5 \\ 54.4 & 14.6 \\ 54.7 & 14.7 \\ 55.0 & \\ 54.1 & 14.7 \\ 54.5 & 14.8 \\ 54.4 & 14.7 \\ 54.4 & 14.9 \\ 54.0 & 13.9 \\ 53.4 & 14.9 \\ 54.4 & 15.0 \\ 53.9 & 14.9 \\ 54.5 & 06.1 \\ 54.2 & 09.4 \\ 54.3 & 10.0 \\ 54.6 & 10.0 \\ & 10.6 \\ 5.0 & 11.4 \\ 54.9 & 11.5 \\ & 12.1 \\ 54.7 & 12.9 \\ 54.1 & 13.5 \\ 54.4 & 13.6 \\ 54.4 & 13.7 \\ 54.2 & 13.8 \\ 54.1 & \\ & 14.6 \\ 54.1 & \end{array}$

54.1

54.2

54.2

54.3

53.9

54.2

54.4

54.2

54.2

54.3

54.4

54.3

54.1

54.2

14.7

14.4
47.8

47.6

47.8

48.1

15.5

$12 . \overline{0}$

$\begin{array}{ll}47.3 & 20.5 \\ 47.9 & 24.5\end{array}$

12.9

$\begin{array}{ll}47.4 & 08.5 \\ 46.9 & 16.7\end{array}$

$\begin{array}{ll}46.7 & 17.7\end{array}$

$47.2 \quad 16.5$

$45.9 \quad 10.0$

$47.3 \quad 09.3$

$47.2 \quad 08.6$

47.2

46.9

46.2

47.3

460

47.1

46.5

46.9

47.2

47.1

47.1

46.4

47.0

47.3

19.9

14.9

092

14.1

195

20.1

19.1

13.2

11.1

08.7

14.9

04.3

1.3

11.6

08.5

04.0

46.7

07.0

11.1569

$08.7 \quad 577$

18.2570

46.3

11.7560

$17.7 \quad 572$

45.6

$131 \quad 569$

17.3568

03.2560

14.1571

$16.0 \quad 567$

04.4569

06.4567

11.5567

$15.156 ?$

$13.0 \quad 570$ 
Tahla 6: Cantinuad

Bath House Spring

Qote Time/hr Flow/dm ${ }^{3}$ min $^{-1}$ Tempi"

$\begin{array}{rll}215 / 95 & 15 & 44.2 \\ 2112195 & 17 & 43.8 \\ 2 / 22 / 95 & 10 & 44.8 \\ 3 / 195 & 18 & 42.6 \\ 3116195 & 13 & 45.2 \\ 312495 & 15 & 44.6 \\ 3 / 29 / 95 & 09 & 45.2 \\ 4 / 16 / 95 & 15 & 44.6 \\ 4 / 29 / 95 & 20 & 45.6 \\ 5 / 395 & 09 & 45.4 \\ 5 / 1 / 95 & 19 & 43.0 \\ 5121 / 95 & 19 & 43.0 \\ 512195 & 16 & 42.2\end{array}$

54.2

54.3

54.1

54.4

54.4

54.6

54.5

53.8

54.4

54.0

55.0

54.9

54.2
St. Michael's Spring

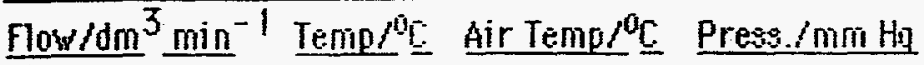

$15.3 \quad 572$

$06.0 \quad 562$

$20.0 \quad 570$

$12.0 \quad 563$

$21.2 \quad 573$

$18.1 \quad 562$

$03.5 \quad 569$

$21.4 \quad 566$

$13.5 \quad 568$

$22.1 \quad 565$

$20.8 \quad 563$

$23.0 \quad 569$

26.7567 
(56/2/90+ $56 / 1 / 2$ woy) fied

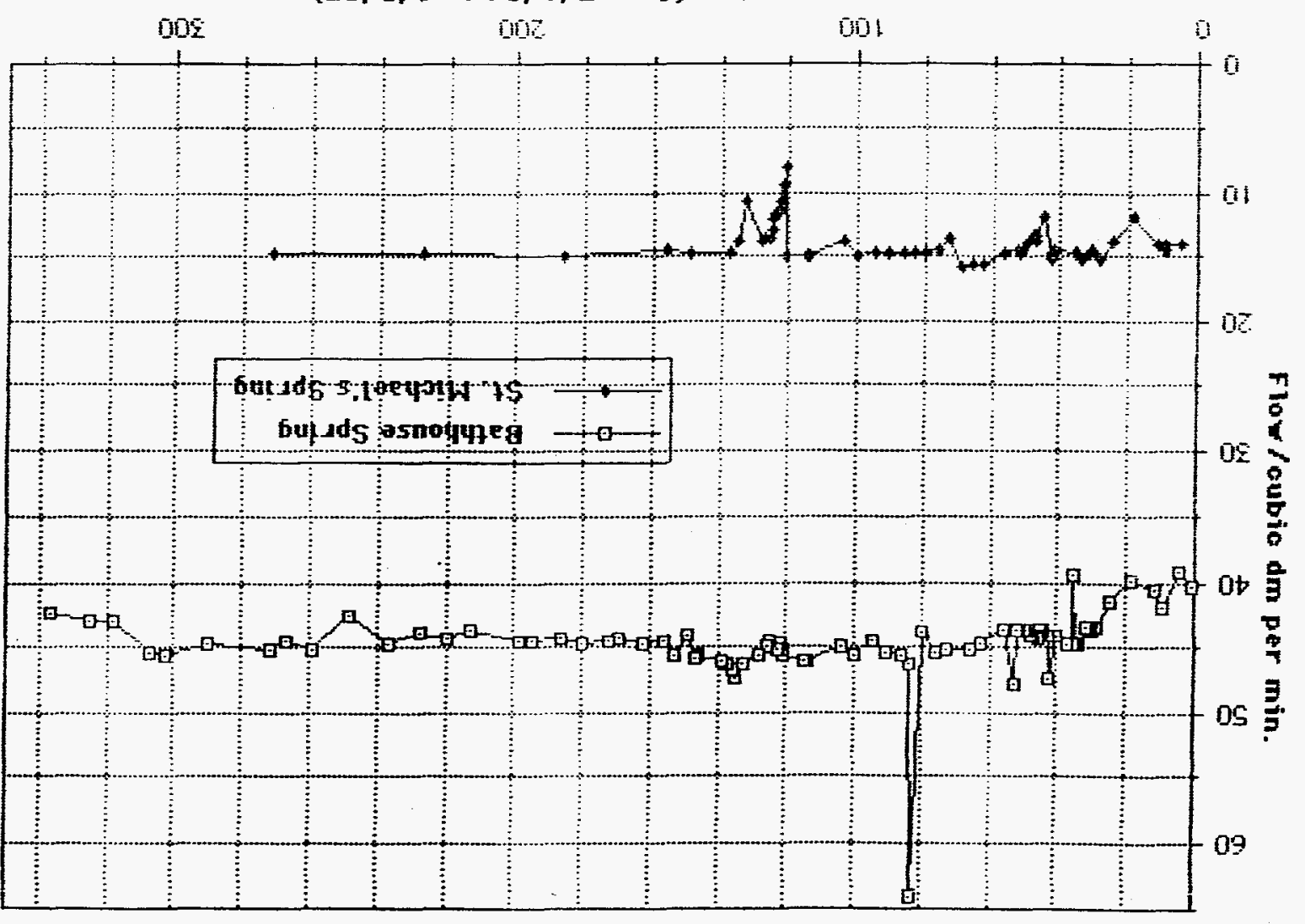

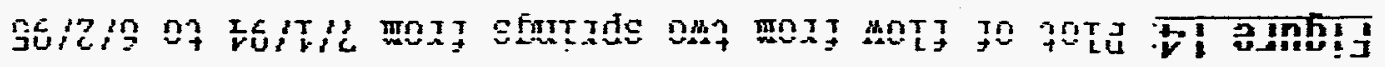


Finüure is: Piot of temperatures of two springs from $7 / 9 / 94$ to $6 / 2 / 95$

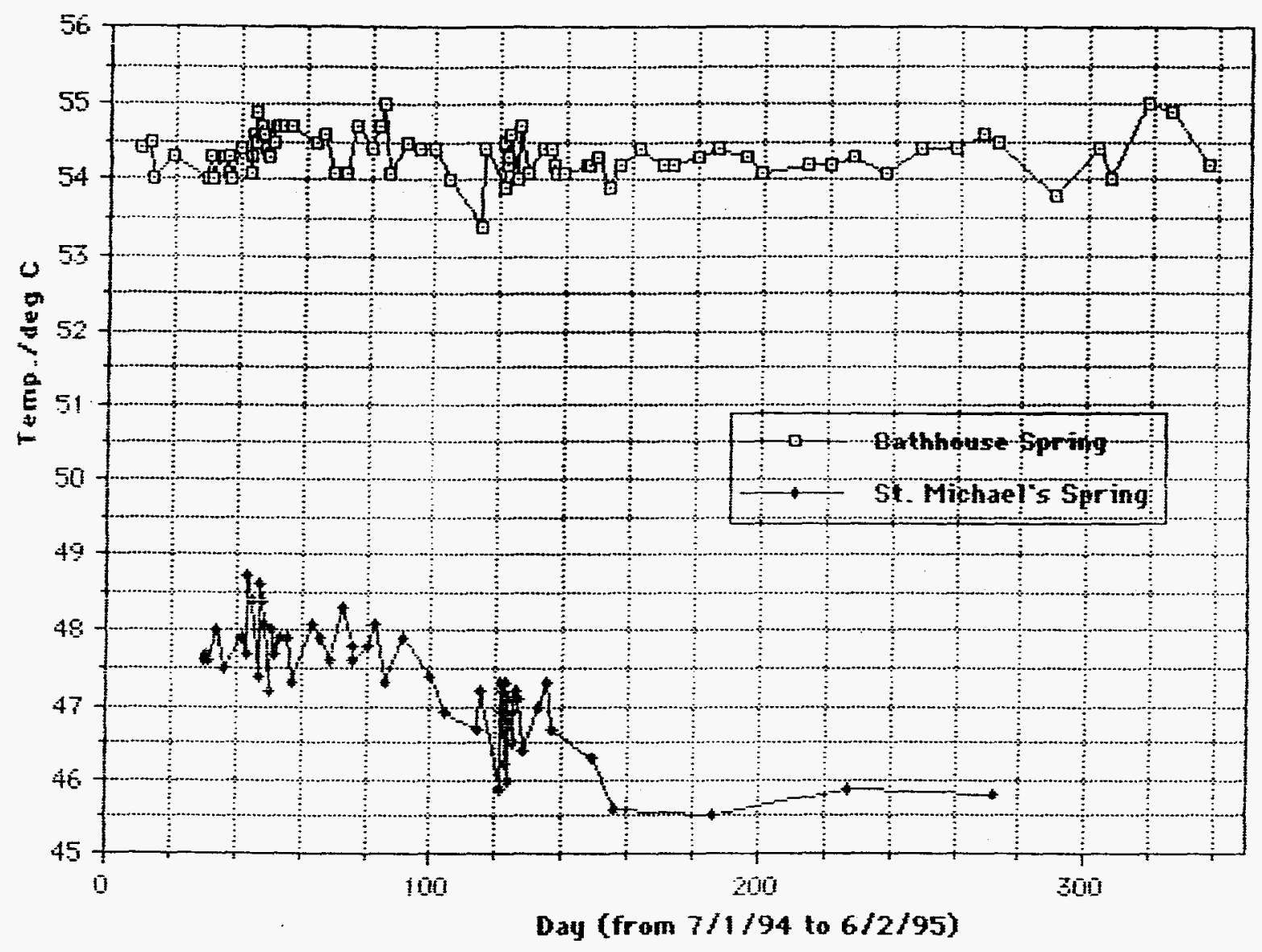


Figure 16: plot of bethhouse spring flow ys atmospheric pressure

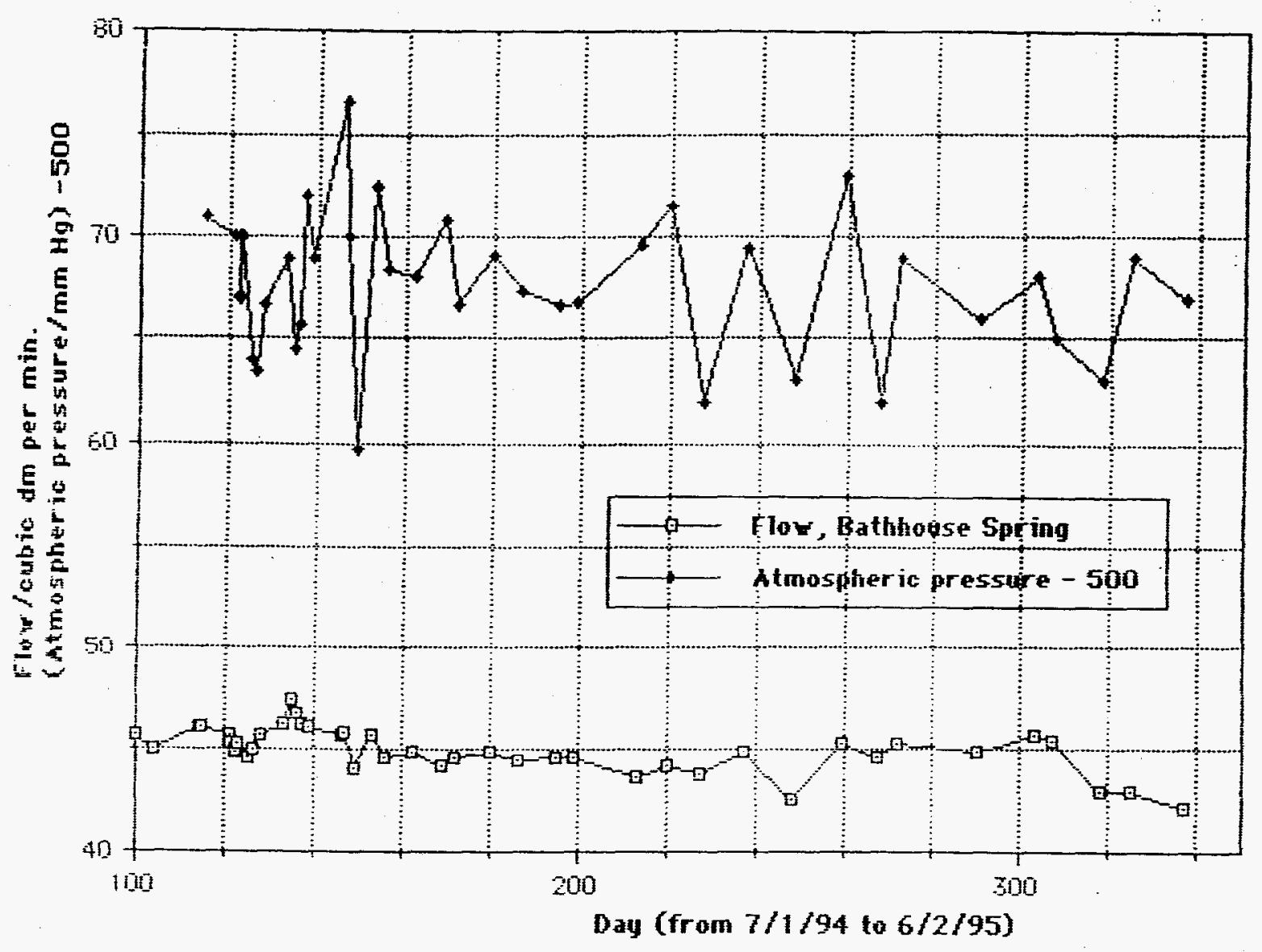


Figure 17: Plot of bathhouse temperature ys air temperature

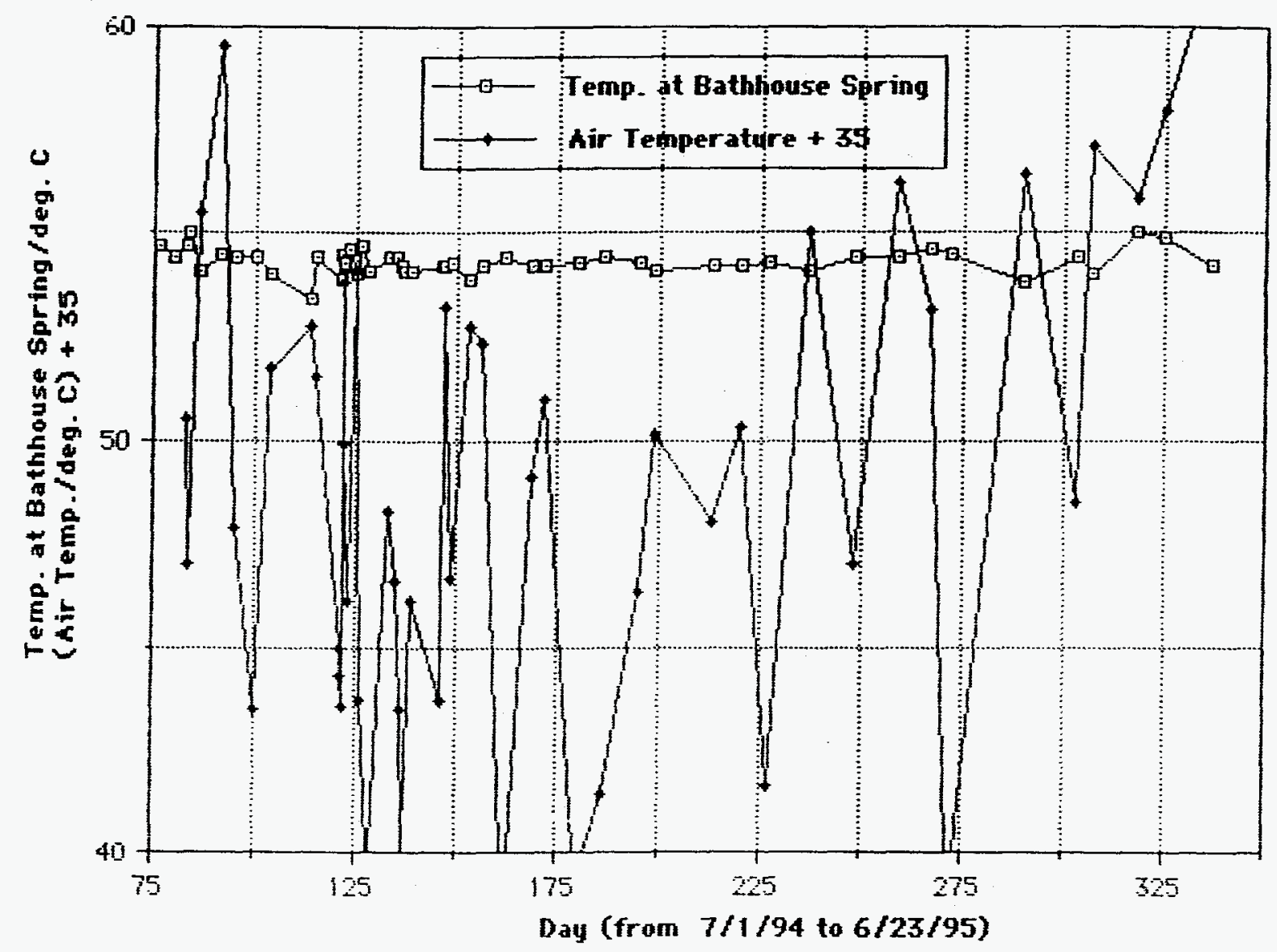

In June, 1995, sensors to measure temperature and flow were installed at the outiet of the tathhouse spring by Sandia National Laboratories. These were intended to provide a continuaus record of data that previously had been collected only intermittently. A record of these dats, as provided by Sandia Laboratories, is given in Figures 18 and 19. 
Figure 18: Flot of bathhouse spring flow rate (UWC and Sandia data)

\section{Spring Flow Rate (GPM)}

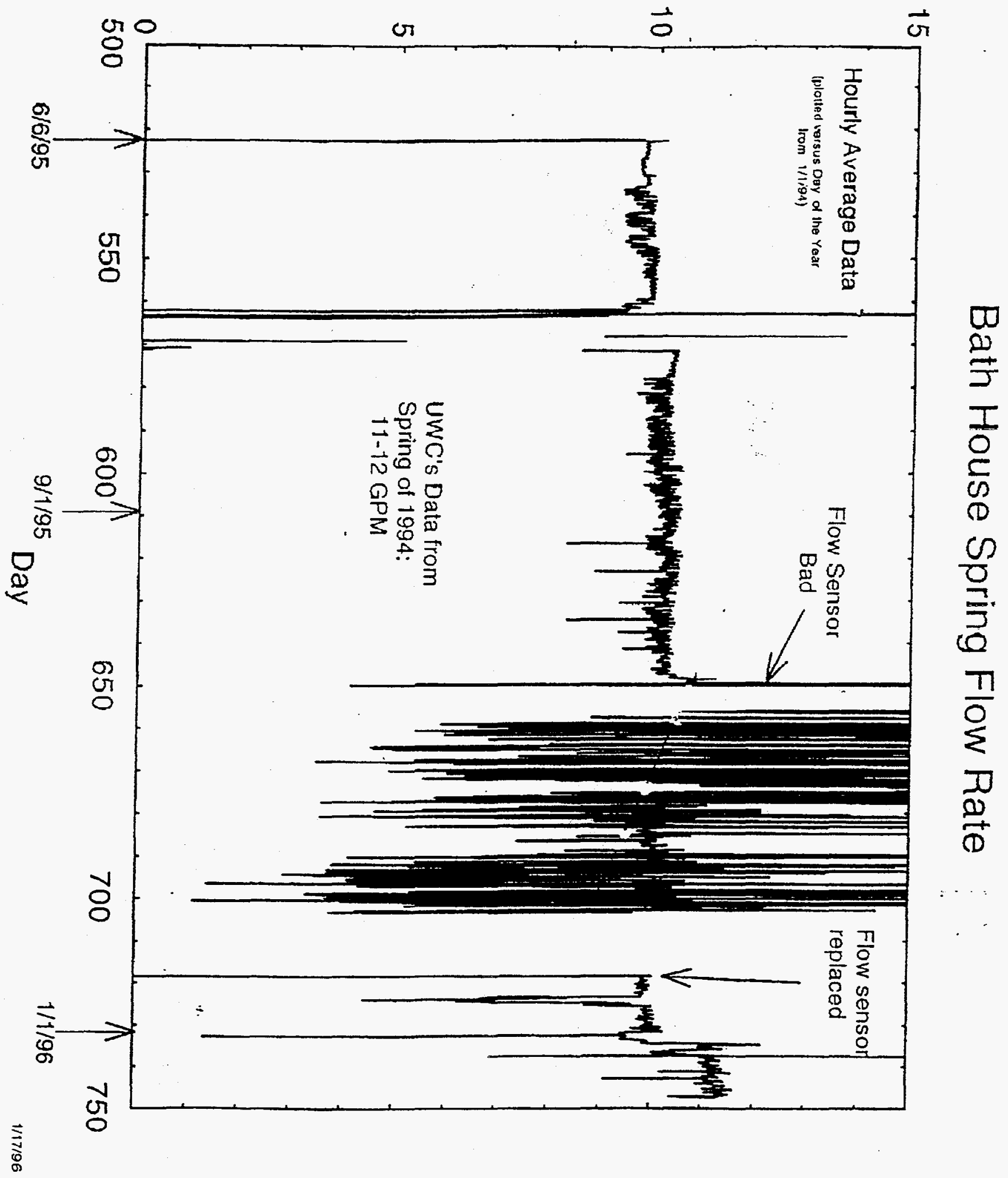


Figure 19: Flot of bathhouse spring temperature (UWC and Sandia data)

Spring Water Temperature $\left({ }^{\circ} \mathrm{F}\right)$

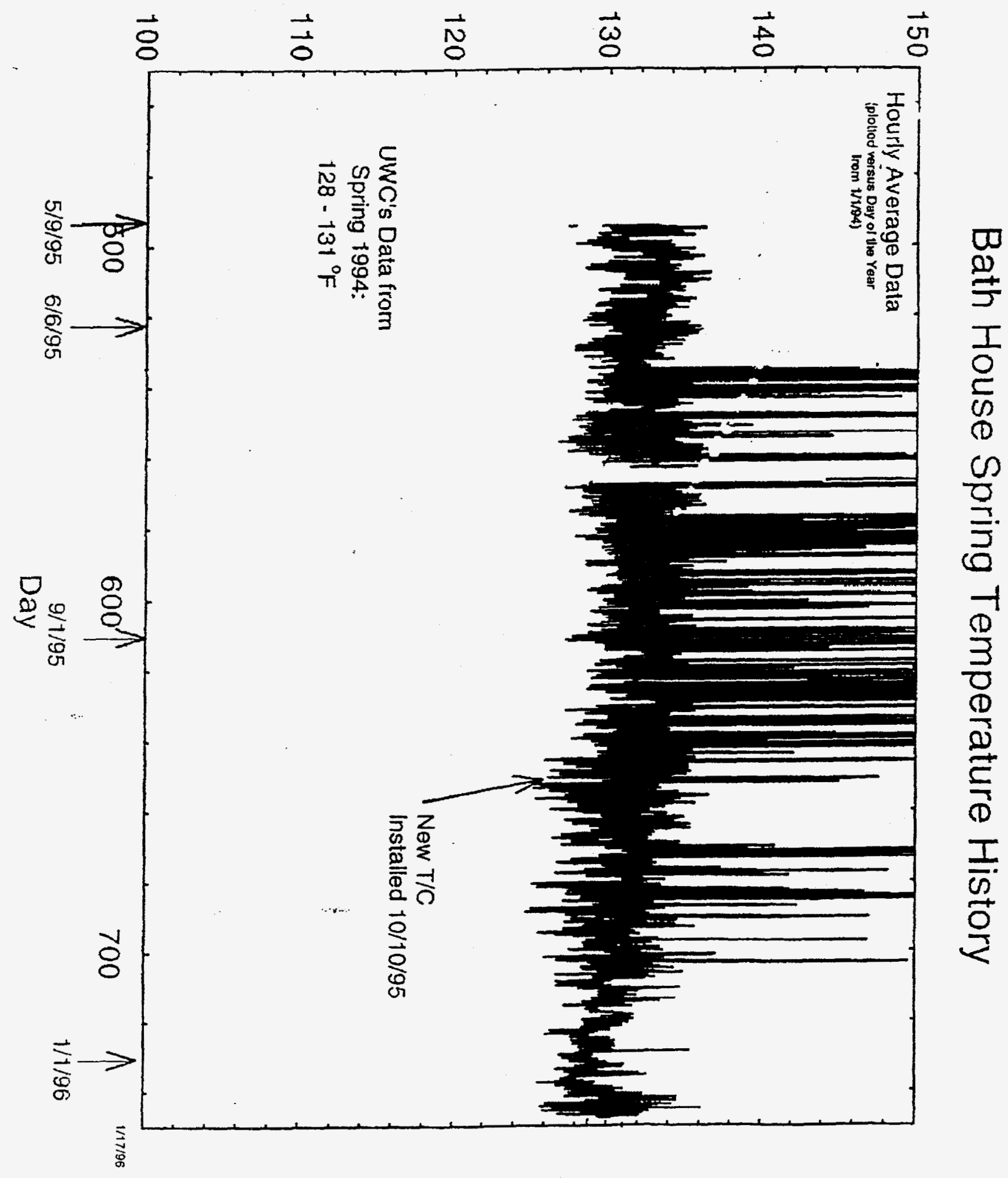




\section{Chemical and Physical Analyses}

A number of samples from springs, seeps, and different river locations were collected and analyzed at Los Alamos National Laboratory. The results of these analyses are qiven in Table 7 . Three samples from springs were collected in the summer of 1993. These analyses are given in Table 8 [11]. Measurements of $\mathrm{pH}$ were recorded in the field and in the laboratory (indicated as $\mathrm{F}$ and $\mathrm{L}$ in the tables). The field measurements are not reliable in many cases because the $\mathrm{pH}$ meter used was not calibrated before each use, and was found to be in serious error on one occasion. Two samples were taken at the bath house spring to compare the effect of filtering or not filtering on andyses that might be done in school laboratories, especially determination of $\mathrm{Na}^{+}, \mathrm{Cl}^{-}, \mathrm{F}^{-}, \mathrm{SiO}_{2}, \mathrm{CO}_{3}{ }^{2-}, \mathrm{HCO}_{3}{ }^{-}$, conductivity, and $\mathrm{pH}$ (samples UWC94-34 (filtered) and UWC94 34R (unfiltered)). Samples UWC94-35 and UWC94-36 were prepared as standards for analysis of chloride and fluaride, respectively. with concentrations being checked ty analysis at LANL. In Taties 7 and 8 are calculated ratios of several pairs of elements. These are considered tet ter indications of a common source than are values for individual ions [29]. The last columns are calculated temperatures for several geothermometers. The list below identifies the geothermometers according to the notation used in Tables 7 and 8 .

\begin{tabular}{|c|c|}
\hline toc & Quart 2 , conductive (no steam loss) \\
\hline tOA & Quartz, adiabatic (maximum steam loss) \\
\hline $\operatorname{tNK}(\mathrm{F})$ & Sadiun-potassium (Fournier) \\
\hline tNk(T) & Sodium-potossium (Truesdell) \\
\hline NKC 13 & Sodium-potassium-calcium; $t>100^{\circ} \mathrm{C}$ \\
\hline tNKC 43 & Sodium-potassium-calcium; $t<100^{\circ} \mathrm{C}$ \\
\hline LAM & Amorphous silica \\
\hline $\mathrm{tCH}$ & Chalcedony \\
\hline IL(d) & Sodium-lithium; $[\mathrm{Cl}]<10000 \mathrm{ppm}$ \\
\hline (c) & Sodium-lithium; $[\mathrm{Cl}]>10000 \mathrm{ppm}$ \\
\hline (d) & Lithium; $[\mathrm{C}]]<10000 \mathrm{pom}$ \\
\hline (c) & Lithium; $[\mathrm{Cl}]>10000 \mathrm{ppm}$ \\
\hline & Magnesium-lithium \\
\hline & Potassium-magnesium \\
\hline & $\begin{array}{l}\text { a term appearing in the sodium-potassium-calcium } \\
\text { geothermometer equation }\end{array}$ \\
\hline
\end{tabular}


Table 7: Chemical analyses of spring and river samples, 1994 NOPTIERH NEA KEXICD TIEPWOL HATERS

\begin{tabular}{|c|c|c|c|c|c|c|c|c|c|c|c|}
\hline SAYPLE & DESCRIPTION & $\begin{array}{c}\text { DATE } \\
\text { W/OO/YY }\end{array}$ & $\underset{-C}{\text { TEMP }}$ & Am & ppa & $\begin{array}{l}\text { Std. D. } \\
+1-\end{array}$ & As & ppa & $\begin{array}{l}\text { Std. D. } \\
+1-\end{array}$ & $\mathrm{Ba}$ & $\begin{array}{l}\text { Std. } D . \\
+1-\end{array}$ \\
\hline Lesc94-1 & Main Bath House & $06 / 22 / 94$ & 54.5 & 0.0011 & 0.24 & 0.02 & 0.0023 & 0.51 & 0.01 & 0.01 & 0.01 \\
\hline Wucst-2 & Concrete Slab & $06 / 22 / 94$ & 54.0 & 10.0005 & 0.22 & 0.01 & 0.0025 & 0.51 & 0.01 & $\{0.01$ & \\
\hline$w_{1034-3}$ & Seep below Hong. by survey marker & $06 / 22 / 94$ & 42.0 & $\{0.0005$ & 0.18 & 0.01 & 0.0031 & 0.51 & 0.01 & 0.02 & 0.01 \\
\hline $\operatorname{Lucs4-4}$ & River above Spring & $06 / 22 / 94$ & 21 & 0.0605 & 0.14 & 0.02 & 10.0002 & 10.01 & & 0.04 & 0.01 \\
\hline uncy-5 & River belon Power House & 06/22/94 & ट2 & 50.0005 & 0.14 & 0.02 & 0.0003 & 0.02 & 0.01 & 0.03 & 0.01 \\
\hline uxcy-14 & River below Bower Huse & $07 / 01 / 94$ & 27 & 10.0005 & 0.14 & 0.01 & 0.0012 & 0.18 & 0.01 & 0.04 & 0.01 \\
\hline uxc94-15 & River above Spring & $07 / 01 / 94$ & 22 & 10.0005 & 0.17 & 0.02 & 0.0008 & 0.08 & 0.01 & 0.05 & 0.01 \\
\hline tuc98-16 & Bath House Spring & $07 / 01 / 94$ & 54 & 10.0005 & 0.05 & 0.01 & 0.0025 & 0.50 & 0.01 & 0.01 & 0.01 \\
\hline uncs4-17 & Spring under slab & $07 / 01 / 94$ & 54 & 10.0005 & 0.03 & 0.01 & 0.0026 & 0.53 & 0.01 & 10.01 & 0.01 \\
\hline Lac94-18 & Seep near Rozo & $07 / 01 / 94$ & 42 & 10.0005 & 10.02 & & $\dot{0} .0034$ & 0.53 & 0.01 & 0.02 & 0.01 \\
\hline UxCS4-ES & Bath House Spring & $07 / 13 / 94$ & 53 & 10.0005 & $10.0 E$ & & $0.002\}$ & $0.5 !$ & 0.01 & 0.01 & 0.01 \\
\hline Uucst-26 & Seep near Road & $07 / 13 / 94$ & 41.2 & 10.0005 & 10.02 & & 0.0031 & 0.53 & 0.01 & 0.02 & 0.01 \\
\hline Lxc94-27 & Spring unders siab & $07 / 13 / 94$ & 52.7 & 10.0005 & 10.02 & & 0.0028 & 0.53 & 0.01 & 10.01 & 0.01 \\
\hline $\operatorname{arcs4-28}$ & River above Spring & $07 / 13 / 94$ & 22.2 & 10.0005 & 0.18 & 0.01 & 0.0003 & 0.02 & 0.01 & 0.04 & 0.01 \\
\hline $\ln x 4-29$ & Aiver belon Prwer House & $07 / 13 / 94$ & 25.4 & 10.0005 & 0.12 & 0.03 & 0.0008 & 0.11 & 0.01 & 0.03 & 0.01 \\
\hline $6 x+30$ & River above causemay & $07 / 13 / 94$ & 23.5 & 60.0005 & 0.15 & 0.02 & 0.0009 & 0.10 & 0.01 & 0.04 & 0.01 \\
\hline uncsi-31 & River Above Springs & $07 / 19 / 94$ & 23.6 & $m$ & 0.14 & 0.03 & 0.0008 & 0.02 & 0.01 & 0.05 & 0.01 \\
\hline Uncs4-32 & River Below Power House & $07 / 19 / 94$ & 29.0 & 一 & 0.08 & 0.02 & 0.0012 & 0.21 & 0.01 & 0.04 & 0.01 \\
\hline UNCS4-33 & Bath House Spring & $07 / 19 / 94$ & 53.2 & - & 0.03 & 0.01 & 0.0029 & 0.49 & 0.01 & 0.02 & 0.01 \\
\hline vess-34 & Bath House Spring, FU & $08 / 05 / 94$ & $5 \overline{5.2}$ & 一 & 80.02 & & -- & -- & - & 0.01 & 0.01 \\
\hline Uxcsi-34R & Bath house Spring, Raw & $08 / 05 / 94$ & 53.2 & $一$ & 0.03 & 0.01 & 一 & - & - & 0.01 & 0.01 \\
\hline $13 \cos 4-35$ & d Cl only & $08 / 08 / 94$ & -- & -- & - & - & $\cdots$ & -- & - & - & - \\
\hline Unces-36 & $\mathrm{Ha}_{\mathrm{a}}$ and $\mathrm{F}$ only & $08 / 08 / 94$ & - & - & -- & $\cdots$ & $-\infty$ & - & - & - & - \\
\hline
\end{tabular}

\begin{tabular}{|c|c|c|c|c|c|c|c|c|c|c|c|c|c|c|c|}
\hline & $B r$ & & 0. & Cd & 1 & co & & (L) & & D. & & 2. & & Stj. D. & $f$ \\
\hline SAMPLE : & $p p *$ & ppa & $+1=$ & PpM & $p p \mathbf{m}$ & ppon & pposs & undo/cn & ppin & $43-$ & pow & $+1-$ & ppw & $+1-$ & $p P$ m \\
\hline $14 \times 34-1$ & 0.79 & 2.05 & 0.12 & 10.00215 & 157 & 10.002 & 40.5 & 878 & 10.002 & & 0.067 & 0.002 & 0.005 & 0.002 & 21.5 \\
\hline $1424-2$ & 0.74 & $1 . x$ & 0.10 & 10.0005 & 154 & 10.002 & 20.6 & 870 & 0.07 & 0.01 & 0.066 & 0.002 & 0.005 & 0.002 & 21.8 \\
\hline C94-3 & 0.73 & 53 & 0.13 & 10.0005 & 152 & 10.002 & 18.4 & 869 & 30.002 & & 0.060 & 0.002 & 10.002 & & 21.3 \\
\hline Cxy-4 & 10.02 & 8.6 & 0.9 & $\$ 0.0005$ & 1.55 & 10.002 & 7.7 & 232 & 10.002 & & 0.004 & 0.002 & 10.002 & & 0.वृ \\
\hline$c 94-5$ & 0.06 & 6.9 & 0.9 & 10.0005 & 3.62 & 10.002 & 8.3 & 221 & 10.002 & & 10.002 & & 10.002 & & 0.48 \\
\hline C94-14 & 0.30 & 39.7 & 0.4 & 10.0005 & 2.4 & 10.002 & 11.4 & 492 & 10.002 & & 0.012 & 0.002 & $\$ 0.002$ & & 5.28 \\
\hline $694-15$ & 0.04 & 4.1 & 1.1 & 10.0005 & $7 . \dot{x}$ & $0.002^{3}$ & 10.1 & 312 & 10.002 & & 10.002 & & 10.002 & & 0.47 \\
\hline-16 & 0. & 02 & 0.08 & 10.0005 & 150 & 10.002 & 17.6 & 862 & 10.002 & & 0.068 & 0.002 & 10.002 & & 20.2 \\
\hline 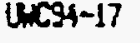 & 0.70 & 53 & 0.04 & 10.0005 & 150 & 10.002 & 19.1 & 860 & 10.002 & & 0.068 & 0.002 & 10.002 & & 20.5 \\
\hline 10 & 0.74 & 55 & 0.08 & 10.0005 & 150 & 10.002 & 16.6 & 865 & 0.002 & 0.002 & 0.077 & 0.002 & $\$ 0.002$ & & 20.5 \\
\hline -25 & 0 & 26 & 0.02 & 10.0005 & 150 & 10.002 & 17.9 & 860 & 10.002 & & 0.068 & 0.002 & 10.002 & & 20.3 \\
\hline & & 63 & 0.09 & 10.0005 & 98 & 10.6 & .2 & 862 & 10.002 & & 0.071 & 0.002 & 0.002 & 0.002 & 20.0 \\
\hline 27 & 78 & 78 & $\infty$ & .0005 & 150 & 10. & .4 & 1 & 10.002 & & 0.068 & 0.002 & 10.002 & & 20.2 \\
\hline & .02 & .5 & 0.6 & & 91 & 0. & .5 & 7 & 10.002 & & $10 . \infty 02$ & & 0.002 & 0.002 & 0.37 \\
\hline $4-29$ & 0.17 & 4 & 0.7 & & 8 & 0. & {$[2,3]$} & 20 & e & & 13 & 0.002 & to. & & 4.22 \\
\hline $1034-30$ & 0.17 & .5 & 0.1 & 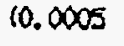 & 5 & 0.00 & 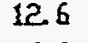 & 37 & 0.002 & & 0.012 & $8:$ & .002 & & 3.68 \\
\hline $1094-31$ & 10.02 & 1.7 & 0.4 & 一 & 46 & - & 9.8 & 312 & - & - & -- & - & - & $\cdots$ & 0.63 \\
\hline wCS4-32. & 0. & .1 & 0.9 & - & 65.7 & -- & 9.3 & 55 & $\cdots$ & - & - & - & - & 一 & 8. 60 \\
\hline $\operatorname{LCS}_{4}-33$ & 0.76 & 29 & 05 & 一 & 155 & - & 0 & 87. & $\cdots$ & $\cdots$ & -- & - & $\cdots$ & - & 21.3 \\
\hline 34 & 18 & 25 & 0.03 & - & 156 & $\cdots$ & 6 & 275 & - & $\cdots$ & -- & --- & - & - & 21.5 \\
\hline Cr & 0.78 & 3.45 & 0.10 & 一 & 157 & - & 19.3 & 73 & - & $\cdots$ & -- & $\cdots$ & - & - & 21.1 \\
\hline & 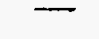 & - & $\cdots$ & $\cdots$ & 1.9 & - & - & - & $\cdots$ & $\cdots$ & -- & $\cdots$ & $\cdots$ & - & $\cdots$ \\
\hline$x^{2} 94-36$ & -- & $\cdots$ & $-\cdots$ & - & $\cdots$ & $\cdots$ & - & 一 & - & - & - & -- & - & - & - \\
\hline
\end{tabular}


Table 7, continued

\begin{tabular}{|c|c|c|c|c|c|c|c|c|c|c|c|c|c|c|c|}
\hline & $F$ & .0. & $1 \mathrm{col}$ & $\mathrm{Hg}$ & 1 & $k$ & Std. D. & li & Std. D. & $\mathrm{Hg}$ & & & d. D. & 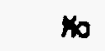 & \\
\hline $\begin{array}{l}\text { SAPCE } \\
\text { urCS4-1 }\end{array}$ & $\begin{array}{r}p q= \\
10.01\end{array}$ & $+1-$ & $\begin{array}{r}\text { ppm } \\
37.0\end{array}$ & $\begin{array}{r}p p x \\
00,0002\end{array}$ & $\begin{array}{r}\text { ppu } \\
\text { co. Ol }\end{array}$ & $\begin{array}{r}\text { ppm } \\
5.60\end{array}$ & $\begin{array}{l}+1- \\
0.02\end{array}$ & $\begin{array}{r}\text { ppm } \\
0.26\end{array}$ & $\begin{array}{l}7 /- \\
0.01\end{array}$ & $\begin{array}{r}0 p \\
0.07\end{array}$ & $\begin{array}{l}+1- \\
0.01\end{array}$ & $\begin{array}{r}p p= \\
10.01\end{array}$ & $+1-$ & $\begin{array}{r}\text { ppos } \\
0.005\end{array}$ & $\begin{array}{l}+1- \\
0.002\end{array}$ \\
\hline Iucs4-2 & 0.10 & 0.01 & 57.1 & 10.0002 & $\{0.01$ & 5.52 & 0.01 & 0.25 & 0.01 & 0.03 & 0.01 & 0.02 & 0.01 & 0.004 & 0.002 \\
\hline [x<94-3 & 10.01 & & 66.0 & 10.0002 & 10.01 & 5.55 & 0.04 & 0.27 & 0.01 & 0.09 & 0.01 & 10.01 & & 0.005 & 0.002 \\
\hline$x 94-4$ & 0.02 & 0.01 & 111 & 10.0002 & 10.01 & 0.69 & 0.01 & 10.01 & & 2.75 & 0.04 & 0.02 & 0.01 & 0.002 & 0.002 \\
\hline$x 94-5$ & 0.02 & 0.01 & 101 & 10.0002 & 10.01 & 0.79 & 0.02 & 0.01 & 0.01 & 2.62 & 0.04 & 0.02 & 0.01 & 10.002 & \\
\hline$x 94-14$ & 0.02 & 0.01 & 127 & 10.0002 & 10.01 & 2.67 & 0.01 & 0.12 & 0.01 & 2.63 & 0.06 & 0.02 & 0.01 & 0,006 & 0.002 \\
\hline$x 94-15$ & 10.01 & & 146 & 10.0002 & $\{0.01$ & 1.08 & 0.01 & 0.01 & 0.01 & 3.63 & 0.07 & 0.05 & 0.01 & 0.002 & 0.002 \\
\hline CS4-16 & $\langle 0.01$ & & 61.3 & 10.0002 & 0.01 & 6.03 & 0.02 & 0.37 & 0.01 & 0.05 & 0.01 & 10.01 & & 0.007 & 0.002 \\
\hline urg4-17 & 0.02 & 0.01 & 59.6 & 10.0002 & 0.01 & 6. 15 & 0.02 & 0.36 & 0.01 & 0.07 & 0.01 & 10.01 & & 0.007 & 0.002 \\
\hline $13 \times x_{4}-18$ & 0.01 & 0.01 & 69.4 & 10.0002 & 0.01 & 6.22 & 0.03 & 0.33 & 0.02 & 0.12 & 0.01 & 0.01 & 0.01 & 0.007 & 0.002 \\
\hline Uxc94-25 & 10.01 & & 61.1 & 10.0002 & 0.01 & 6.09 & 0.03 & 0.35 & 0.02 & 0.06 & 0.01 & 10.01 & & 0.007 & 0.002 \\
\hline $4 u \times 94-x$ & 10.01 & & 68.9 & 10.0002 & 0.01 & 6.23 & 0.02 & 0.34 & 0.01 & 0.10 & 0.01 & 10.01 & & 0.007 & 0.002 \\
\hline 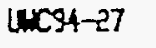 & 0.02 & 0.01 & 50.3 & 10.0002 & 0.01 & 6.09 & 0.04 & $0 . I S$ & 0.02 & 0.03 & 0.01 & 10.01 & & 0.007 & 0.002 \\
\hline $11094-28$ & 0.01 & 0.01 & 149 & 10.0002 & 10.01 & 1.13 & 0.01 & 0.01 & 0.01 & 4.06 & 0.02 & 0.03 & 0.01 & 0.002 & 0.002 \\
\hline$\left(\mathrm{uxS}_{4}-29\right.$ & 0.01 & 0.01 & 134 & 10.0002 & 10.01 & 2.12 & 0.01 & 0.07 & 0.02 & 3.30 & 0.03 & 0.02 & 0.01 & 0.004 & 0.002 \\
\hline uncsi-30 & 0.01 & 0.01 & 145 & 10.0002 & 10.01 & 2.09 & 0.01 & 0.07 & 0.01 & 3.81 & 0.12 & 0.01 & 0.01 & 0.004 & 0.002 \\
\hline uncs-31 & $(0.01$ & & 136 & 10.0002 & - & 1.31 & 0.01 & 0.02 & 0.01 & 3.41 & 0.03 & 0.01 & 0.01 & - & 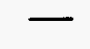 \\
\hline $12 \times 34-32$ & 0.01 & 0.01 & 127 & 30.0002 & - & 3.31 & 0.01 & 0.21 & 0.01 & 2.27 & 0.02 & 0.01 & 0.01 & - & - \\
\hline $12 \operatorname{css}_{4}-33$ & $\langle 0.01$ & & 82.0 & 10.0002 & - & 6.11 & 0.02 & 0.46 & 0.01 & 0.65 & 0.01 & 10.01 & & $\longrightarrow$ & - \\
\hline $14 \times C 34-34$ & 10.01 & - & 59.3 & - & - & 6.08 & 0.04 & 0.42 & 0.01 & 0.05 & 0.01 & 10.01 & - & - & - \\
\hline ULCSA-3AR & 10.01 & - & 57.9 & -- & $\longrightarrow$ & - & -- & 0.39 & 0.01 & 0.04 & 0.01 & 10.01 & - & -- & - \\
\hline $14 C_{4}-35$ & $\longrightarrow$ & -- & $\cdots$ & -- & - & --- & -- & -- & - & - & -- & $\infty$ & - & $m$ & 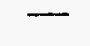 \\
\hline $4 \times c 34-36$ & . & $-\infty$ & -- & - & 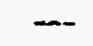 & $\rightarrow$ & - & -- & & & & -- & & & \\
\hline
\end{tabular}

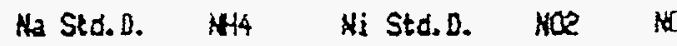

\begin{tabular}{|c|c|c|c|c|c|c|c|c|c|}
\hline SAMPE & ppa & $+1-$ & pq & pps & $+1-$ & ppr & ppir & ppx & $+1-$ \\
\hline $14 \times 34-1$ & 187 & 7 & 0.07 & 10.022 & & 10.02 & 10.02 & 0.002 & 0.002 \\
\hline 41594-2 & 174 & 3 & 0.014 & 0.045 & 0.002 & 10.02 & 60.02 & 10.002 & \\
\hline $34 \times 34-3$ & 177 & 3 & 0.07 & 0.045 & 0.002 & 10.02 & 10.02 & 10.002 & \\
\hline Uncs4-4 & 2.93 & 0.03 & 0.10 & 10.002 & & 10.02 & 10.02 & 10.002 & \\
\hline $14 x_{4}-5$ & 5.81 & 0.02 & 0.07 & 10.002 & & 10.02 & 10.02 & 10.002 & \\
\hline uxc94-14 & 57.9 & 0.2 & 0.09 & 10.002 & & 10.02 & 10.02 & 10.002 & \\
\hline Incs4-15 & 8.30 & 0.08 & 0.08 & 10.002 & & 10.02 & 10.02 & $\langle\overline{.002}$ & \\
\hline unc94-16 & 167 & 2 & 0.07 & 10.002 & & $10 . \infty$ & 10.02 & 0.011 & 0.002 \\
\hline uncs4-17 & 165 & 2 & 0.05 & 10.002 & & 10.02 & 0.03 & 10.002 & \\
\hline $12 x+4-18$ & 168 & 1 & 0.06 & 10.002 & & 10.02 & 0.08 & 10.002 & \\
\hline UxC94-25 & 168 & 3 & 0.05 & 10.002 & & 10.02 & 10.02 & 10.002 & \\
\hline $14 \times 94-26$ & 166 & 1 & 0.06 & 10.002 & & 10.02 & 0.05 & 0.014 & 0.002 \\
\hline uncs4-27 & 174 & 1 & 0.05 & 10.002 & & $<0.02$ & 10.02 & 0.002 & 0.002 \\
\hline uxc94-28 & 6.71 & 0.04 & 0.05 & 10.002 & & 40.02 & 10.02 & 10.002 & \\
\hline uxs4-29 & 38.7 & 0.5 & 0.05 & 10.002 & & 10.02 & 0.02 & 60.002 & \\
\hline uxcs4-30 & 36.8 & 0.7 & 0.27 & 10.002 & & $\{0.02$ & 0.07 & 10.002 & \\
\hline LAC94-31 & 10.1 & 0.1 & - & - & - & 10,02 & 10.02 & -- & - \\
\hline $14 \times 94-32$ & 89.6 & 0.5 & $\rightarrow$ & - & م & 10.02 & $(0.02$ & - & 一- \\
\hline$u_{1 \times 94-33}$ & 185 & 4 & - & -- & 一 & 10.02 & 10.02 & -- & - \\
\hline uncs4-34 & 177 & 3 & $\rightarrow$ & $\longrightarrow$ & $\cdots$ & 10.02 & 10.02 & - & - \\
\hline $14 C 34-34 R$ & 166 & 8 & -- & - & - & $10.0 \hat{2}$ & 0.24 & - & $\cdots$ \\
\hline unse-35 & - & - & - & - & - & - & $\cdots$ & -- & - \\
\hline$\left(\operatorname{sic}_{4}-36\right.$ & $\rightarrow$ & - & $-\infty$ & -- & - & -- & - & - & -- \\
\hline
\end{tabular}

aH (L) $\infty$ 9.07 9.09 8.82 8.80 9.45 9.35 9.51 9. 61 9.55 9.66 9.70 9.70 9.26 9.42 9.41

8.69 6. 86 9.11

$$
\begin{aligned}
& 9.27 \\
& 9.03 \\
& 8.37 \\
& 8.06 \\
& 8.15 \\
& 8.55 \\
& 8.28 \\
& 8.96 \\
& 8.99 \\
& 8.90 \\
& 8.95 \\
& 8.93 \\
& 8.98 \\
& 8.52 \\
& 8.63 \\
& 8.62 \\
& 8.41 \\
& 8.41 \\
& 8.90 \\
& 8.96 \\
& 9.02
\end{aligned}
$$

PO4

ppos

10.05

10.05

10.05

10.05

10.05

10.05

10.05

10.05

10.05

40.05

10.05

10.05

30.05

10.06

10.05

10.05

10.05

10.05

10.05

60.05

10.05 at Std. D. ppa $+1-$ 0.0810 .002 $0.078 \quad 0.002$ $0.084 \quad 0.002$ 10.002

$\begin{array}{lll}0.002 & 0.002\end{array}$ $0.025 \quad 0.002$ 10.002

0.0810 .002 0.0810 .002 $0.082 \quad 0.002$ 0.0820 .002 $\begin{array}{lll}0.080 & 0.002\end{array}$ $0.082 \quad 0.002$ $0.002 \quad 0.002$

$0.019 \quad 0.002$ $\begin{array}{lll}0.017 & 0.002\end{array}$
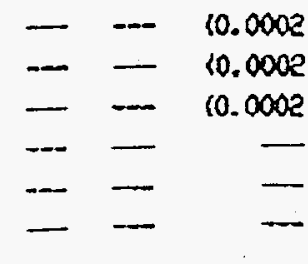
Table 7 , continued

\begin{tabular}{|c|c|c|c|c|c|c|c|c|c|c|c|c|c|c|}
\hline \multirow[b]{2}{*}{ SARPE : } & \multirow{2}{*}{ - Se } & \multicolumn{2}{|c|}{ Si Std.0. } & \multirow{2}{*}{$\begin{array}{l}\text { Side } \\
\text { Calc }\end{array}$} & \multirow{2}{*}{$\begin{array}{l}\mathbf{S 0 4} \\
p p q u\end{array}$} & \multirow{2}{*}{$\begin{array}{c}5203 \\
\rho p n\end{array}$} & \multicolumn{2}{|c|}{ So std..} & \multicolumn{2}{|c|}{ In Std. B. } & \multirow{2}{*}{$\begin{array}{l}\text { TDS } \\
\text { ppre }\end{array}$} & \multirow{2}{*}{$\begin{array}{l}\text { Cation } \\
\text { Sume }\end{array}$} & \multirow{2}{*}{$\begin{array}{l}\text { Anion } \\
\text { Sum }\end{array}$} & \multirow{2}{*}{ Balance } \\
\hline & & ppan & $+1-$ & & & & ppa & $+1-$ & ppon & 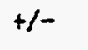 & & & & \\
\hline $4 x+34-1$ & 10.0002 & 2.2 & 0.4 & 68.9 & $\$ 1.2$ & 10.01 & 0.13 & 0.01 & 0.01 & 0.01 & 563.1 & 8.45 & 8.403 & 0.008 \\
\hline $\cos 2 ?$ & 10.0002 & 31.2 & 0.3 & 65.8 & 40.5 & 10.01 & $0.1 !$ & 0.01 & 10.01 & & 544.5 & 7.879 & 7.983 & \\
\hline $94-3$ & 10.0002 & 30.8 & 0.2 & 5.9 & 40.1 & 10.01 & 0.10 & 0.01 & 0.01 & & 551.0 & 8.038 & 7.564 & \\
\hline $94-4$ & 10.0002 & 4.73 & 0.05 & $10 . !$ & 9.98 & 80.01 & 0.13 & 0.01 & 0.01 & 0.01 & 186.0 & 2.324 & 2.339 & .00 \\
\hline $94-5$ & 10,0002 & .95 & 0.09 & 10.5 & 10.7 & 0.01 & 0.13 & 0.01 & 10.01 & & 181. & 2.256 & 2. & $w=$ \\
\hline $9 x-14$ & 10.0002 & 13.2 & 0.1 & 28.2 & 25.7 & 10.01 & 0.16 & 0.01 & 10.01 & & $\$ 5$. & 4.827 & 4.1 & w \\
\hline $294-15$ & 10.0002 & 63 & 0.01 & 12.0 & 15.4 & 10.01 & 0.18 & 0.01 & $\{0.01$ & & 259.1 & 3.418 & 3.283 & .040 \\
\hline $294-16$ & 10.0002 & 3.! & 0.1 & 70.8 & 9.1 & 10.01 & 0.12 & 0.01 & 10.01 & & 53 & 7.687 & 1.726 & 0.005 \\
\hline $4-17$ & 10.0002 & 2.5 & 0.7 & 69.6 & 9.2 & 10.01 & $0 . ! 1$ & 0.01 & 0.01 & & $f$ & 7.519 & 7.768 & 0.0192 \\
\hline $4-18$ & 10.0002 & 1.8 & 0.3 & 5.9 & 8.5 & $(0.01$ & i. 10 & 0.01 & 0.01 & 0.01 & $5+1.7$ & $i .756$ & 7.831 & -0.0050 \\
\hline $4-25$ & 10.0002 & .5 & 1.5 & 3.8 & .8 & 10.01 & $0 .: 2$ & 0.01 & 0.01 & 0.01 & $s$ & 7.7 & i. 732 & 0.0004 \\
\hline 1426 & 10.0008 & 1.0 & 0.9 & 66.3 & 5.9 & 10.01 & 0.10 & 0.01 & 10.01 & & 35.3 & 7.872 & 7.697 & -0.0033 \\
\hline-27 & 10.0002 & .6 & 0.7 & 69.8 & 8.5 & 10.01 & 0.11 & 0.01 & 10.01 & & 543.1 & 7.5 & i. 785 & 0.0312 \\
\hline CS4-28 & 10.0002 & 30 & 0.01 & 11.3 & 3.6 & 10.01 & $0.1 i$ & 0.01 & 10.01 & & 257.7 & 3.4 & 3.267 & 0.0424 \\
\hline $94-29$ & 10.0002 & 0.1 & 0.1 & 21.6 & 2.7 & $(0.01$ & 0.15 & 0.01 & 80.01 & & 318.2 & 4.2 & 4.282 & -0.0063 \\
\hline $94-30$ & 10.0002 & 9.24 & 0.03 & 19.8 & .6 & 10.01 & 0.20 & 0.01 & 0.02 & 0.01 & 57.5 & 4.6 & 18 & 0.0232 \\
\hline $94-31$ & $\{0.0002$ & 30 & a. 04 & 3.2 & 18.9 & - & .15 & 0.01 & 10.01 & & 38.9 & 7 & .250 & $-0.18+2$ \\
\hline $34-32$ & 10.0002 & .9 & 0.1 & .9 & 28.9 & - & .15 & 0.03 & 10.01 & & 94.7 & 5.570 & .310 & $0.04 \pi$ \\
\hline $94-33$ & 10.0002 & 32.5 & 7 & 8 & .5 & $\cdots$ & .14 & 0.01 & 10.01 & & 1.9 & 1 & .944 & 0.0606 \\
\hline $4-34$ & - & 33.8 & 0.4 & 2.3 & .2 & - & 3.13 & 0.01 & 0.01 & & 536.7 & 8.081 & 7. 304 & 0.0120 \\
\hline$-34 f$ & $\cdots$ & 2. 4 & 0.2 & 8.3 & +0.7 & - & 0.13 & 0.01 & 0.01 & & - & - & $\cdots$ & - \\
\hline $24-3$ & $\cdots$ & - & - & - & - & - & - & -- & $\cdots$ & & - & - & - & -1 \\
\hline $\cos -36$ & - & - & - & - & 11.0 & - & - & -- & - & 一 & - & - & - & \\
\hline
\end{tabular}

\begin{tabular}{|c|c|c|c|c|c|c|c|c|c|c|c|c|}
\hline SRPLE & $\begin{array}{l}\text { Bra } \\
\text { by af }\end{array}$ & Lua & $\begin{array}{l}\text { f/d } \\
\text { by } x\end{array}$ & by $x \mathrm{ct}$ & $\begin{array}{l}\text { k/C } \\
\text { by wt }\end{array}$ & $\begin{array}{l}\text { Sot/d } \\
\text { 5y Wt }\end{array}$ & $\begin{array}{r}\text { Hedso } \\
\text { by } x t\end{array}$ & $\begin{array}{l}\text { Cs/CL } \\
\text { by wt }\end{array}$ & $\begin{array}{l}\text { gR/c } \\
\text { by } x t\end{array}$ & $\operatorname{tac}_{\alpha}^{\infty}$ & 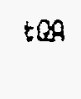 & $\frac{\tan (F)}{\alpha}$ \\
\hline lucs4-1 & 0.0032 & 0.0017 & 0.1369 & 1.1911 & 0.0357 & 0.2524 & 0.235 & 0.0004 & 0.0050 & 117 & 116 & 132 \\
\hline uxc34-2 & 0.0033 & 0.0016 & 0.1416 & 1.1209 & 0.0358 & 0.2530 & 0.3708 & 0.0004 & 0.0048 & 116 & 115 & 135 \\
\hline uncs4-3 & 0.0034 & 0.0018 & 0.1401 & 1.1635 & 0.0365 & 0.2638 & $0.73+2$ & 0.0004 & 0.0048 & 115 & 114 & 134 \\
\hline $\operatorname{loc} 4-4$ & 0.0000 & $0 ; 0000$ & 0.1419 & 1.3903 & $0 .+452$ & 5.4387 & 71.6129 & 0.0025 & 0.0000 & 40 & 48 & 303 \\
\hline uncst-5 $_{4}$ & 0.0052 & $0.00 x 5$ & 0.1257 & 1.5309 & 0.2768 & 2.3010 & 25.1398 & 0.0000 & 0.0157 & 41 & 49 & 245 \\
\hline UACS-14 & 0.0034 & 0.0023 & 0.1188 & 1.1050 & 0.0510 & 0.5095 & 2.4237 & 0.0002 & 0.0057 & $\pi$ & 81 & 159 \\
\hline lexs4-15 & 0.0027 & 0.0014 & 0.0642 & 1.1339 & 0.1475 & 2.1038 & 19.9454 & .0 .0000 & 0.0055 & 45 & 5 & 241 \\
\hline Ixres-16 & 0.0033 & 0.0025 & 0.1347 & 1.1133 & 0.0402 & 0.2507 & 0.4087 & 0.0005 & 0,0050 & 119 & 117 & 143 \\
\hline $13 \times 94-17$ & 0.0035 & 0.0024 & 0.1367 & 1.1067 & 0.0410 & 0.2613 & 0.3973 & 0.0005 & 0.0047 & 118 & 118 & 144 \\
\hline IICS4-18 & 0.0035 & 0.0022 & 0.1367 & 1.1200 & 0.0415 & 0.2567 & 0.4527 & 0.0005 & 0.0049 & 115 & 114 & 144 \\
\hline uxy4-25 & 0.0034 & 0.0023 & 0.1353 & 1.1200 & 0.0406 & 0.2587 & 0.1073 & 0.0005 & 0.0052 & 118 & 116 & 143 \\
\hline Uucsh-26 & 0.0036 & 0.0023 & 0.1361 & 1.1203 & 0.0424 & 0.2510 & $0 .+687$ & 0.0005 & 0.0046 & 115 & 114 & 145 \\
\hline uxcs4-27 & 0.0035 & 0.0023 & 0.1347 & 1.1600 & 0.0406 & $\dot{0} . \pm 567$ & 0.4020 & 0.0005 & 0.0052 & 118 & 116 & 141 \\
\hline$(1 \times C 94-2 B$ & 0.0041 & 0.0020 & 0.0754 & 1. 3666 & 0.2301 & 2. 7699 & 30.3462 & 0.0000 & 0.0000 & 43 & $5 \xi$ & $25 a ́$ \\
\hline $4 x+29$ & 0.0031 & 0.0020 & 0.1179 & 1.0810 & 0.0592 & 0.3782 & 3.7430 & 0.0004 & 0.0047 & 56 & 72 & 170 \\
\hline $8 x \cos 4-30$ & 0.0031 & 0.0022 & 0.1132 & 1.1323 & 0.0643 & 0.8492 & 4,4615 & 0.0004 & 0.0052 & 83 & 69 & 173 \\
\hline LIC94-31 & 0.0021 & $0.002 !$ & 0.0666 & $1.06 \pi$ & 0.1385 & 1.9979 & 14.3763 & 0.0000 & 0.0000 & 37 & 45 & 240 \\
\hline urcs-32 & 0.0032 & 0.0032 & 0.1309 & 1.3486 & 0.0504 & 0.4399 & 1.9330 & 0.0000 & 0.0049 & 82 & 85 & 145 \\
\hline $4 x c_{4}-33$ & 0.0032 & 0.0030 & 0.1374 & 1.1935 & 0.0394 & $\dot{0} .2513$ & 0.4000 & 0.0000 & 0.0049 & 118 & 116 & $! 37$ \\
\hline uncs-34 & 0.0000 & 0.0027 & 0.1578 & 1.1346 & 0.0390 & $0.26+1$ & 0.3801 & 0.0000 & 0.0050 & 120 & 118 & 140 \\
\hline LEx $44-34 R$ & - & 一 & - & - & - & -- & - & - & -- & & & \\
\hline $18 \times 94-35$ & -- & - & - & - & $\ldots$ & - & - & -- & - & & & \\
\hline uncsi-35 & - & -- & - & - & - & - & 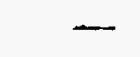 & - & 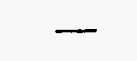 & & & \\
\hline
\end{tabular}


Table 7, continued

\begin{tabular}{|c|c|c|}
\hline & twin & tMels \\
\hline SPYPLE I & ${ }^{\circ} \mathrm{C}$ & ${ }^{\circ} \mathrm{C}$ \\
\hline uncst-1 & 86 & 141 \\
\hline $\operatorname{lacs} 4-2$ & 90 & 143 \\
\hline ucsa-3 & 89 & 141 \\
\hline $12 \times x_{4-4}$ & 303 & 150 \\
\hline Lecst-5 & 223 & 136 \\
\hline Lenc94-14 & 117 & 122 \\
\hline $\operatorname{lec} 94-15$ & 218 & 136 \\
\hline unc94-16 & 99 & 143 \\
\hline uncst-17 & 101 & 145 \\
\hline $14034-18$ & 101 & $14 \sqrt[3]{3}$ \\
\hline Uuc94-25 & 99 & 143 \\
\hline Lecest-at & 102 & 143 \\
\hline [ucsh-27 & 97 & 143 \\
\hline Luc94-28 & $25 !$ & 144 \\
\hline $14 \times 94-29$ & 131 & 122 \\
\hline uncsit-30 & 134 & 122 \\
\hline 1 ucs4-31 & 217 & $14 !$ \\
\hline Uucse-32 & 101 & 121 \\
\hline $12 \operatorname{los}_{4}-33$ & 93 & $1+2$ \\
\hline uncror-34 & 55 & 143 \\
\hline \multicolumn{3}{|l|}{ (u) } \\
\hline \multicolumn{3}{|l|}{$(4 x)-35$} \\
\hline$u x c 94-36$ & & \\
\hline
\end{tabular}


Table 8: Chemical analyses of spring samples, 1993

NORTHERN NEH MEXICO THERMPLL HATERS

\begin{tabular}{|c|c|c|c|c|c|c|c|c|c|c|}
\hline & & DATE & TEP & $\mathrm{Ag}$ & A1 & As & B & Std. D. & $B a$ & . \\
\hline$E \#$ & DESCRIPTION & $\mathrm{MH} / \mathrm{DD} / \mathrm{YY}$ & $\propto$ & ppw & ppm & ppm & ppa & $+1-$ & ppm & $+1-$ \\
\hline -1 Main & se Sorinn. Mont & $-1-193$ & 55.1 & 10.001 & 10.05 & 10.05 & 0.5 & 0.02 & 0.01 & 0.01 \\
\hline & St. Hichael ", Horitazuna & $-i-i j \bar{j}$ & $4 \overline{0} .7$ & 10.001 & $0.0 \bar{j}$ & 10.05 & j. $\bar{j}$ & $\dot{0} .01$ & $i \bar{u} . \hat{v} \mathbf{i}$ & \\
\hline & Central Spg, Montazuma Hot Sprs & $-1-193$ & 53.9 & $<0.001$ & 10.05 & 10.05 & 0.53 & 0.02 & 10.01 & \\
\hline
\end{tabular}

\begin{tabular}{|c|c|c|c|c|c|c|c|c|c|c|c|c|c|c|c|}
\hline & Br & $\mathrm{Ca}$ & Std. $D$. & Cd & $\mathrm{Cl}$ & $\mathrm{Co}$ & 003 & and. \{L\} & $\mathrm{Cr}$ & Std.D. & Cs & Std.D. & $\mathrm{Cu}$ & Std. D. & $F$ \\
\hline SAMFLE \# & ppw & ppre & $+/-$ & pora & ppan & 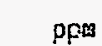 & מpo & unaicas & ه़و & $+i-$ & poia & $+i-$ & ppos & $+i-$ & \\
\hline & t. & 3.34 & 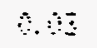 & $\because$ & $\because$ & 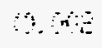 & $\because \quad$ & 50 & Hב & 43 & $8=$ & 4 & be & & \\
\hline & $\therefore 38$ & 5.5 & 0.86 & B. bit & $1:=$ & $\therefore$. & $1 \bar{x}=$ & 35 & 0.0 & & $\therefore$ & $\therefore 60$ & it. & & \\
\hline ints & v. 35 & $\overline{5.44}$ & 0.04 & iv. voi & $\dot{i b i}$ & Wu. WUE & 17.3 & 58 & io. & & u. 061 & v. vie & u. $0 \overrightarrow{\mathrm{s}}$ & $\dot{v} \cdot \dot{v i e}$ & 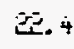 \\
\hline
\end{tabular}

Fe Std.D. HCOJ I K Std.D. Li Std.D. Kg Std.D. Hn Std.D. Mo Std.D. Na Std.D.

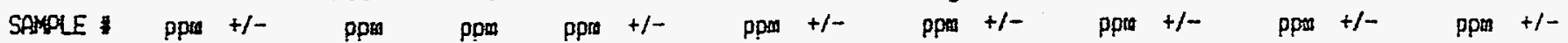
$\begin{array}{lllllllllllllllllll}\text { NNA93-1 } & 0.05 & 0.01 & 59.8 & 0.01 & 5.58 & 0.05 & 0.36 & 0.01 & 0.09 & 0.01 & 0.01 & 0.01 & 0.009 & 0.001 & 177 & 4\end{array}$ $\begin{array}{llllllllllllllll}0.0393-2 & 0.07 & 0.01 & 63.4 & 10.01 & 5.70 & 0.04 & 0.33 & 0.01 & 0.04 & 0.01 & 10.01 & 0.008 & 0.001 & 170 & 2\end{array}$ $\begin{array}{lllllllllllllllll}\text { NNA93-3 } & 0.05 & 0.01 & 62.8 & 0.01 & 5.78 & 0.01 & 0.32 & 0.01 & 0.06 & 0.01 & 10.01 & 0.008 & 0.001 & 176 & 1\end{array}$

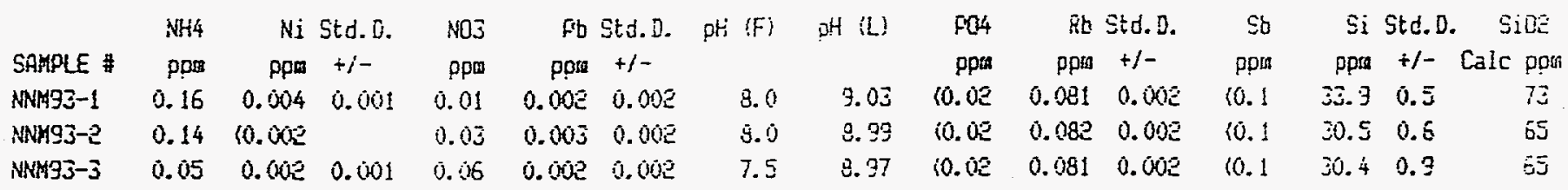

\begin{tabular}{|c|c|c|c|c|c|c|c|c|c|c|c|c|}
\hline & 504 & $\operatorname{sens}$ & Sr & sto. 5. & in & Etd. D. & TDS & Catian & Anion & Balarice & TAM & $t c H$ \\
\hline SAMFLE : & opta & ppon & ppm & $+1-$ & pọar & $+1-$ & porna & Sura & Sun & & $\therefore$ & \\
\hline NNA93-1 & 42.3 & 0.23 & 0.19 & 0.01 & 0.03 & 0.01 & 579.8 & 9.112 & 8.567 & -0.0545 & 3 & 91 \\
\hline $493-2$ & 44.7 & 0.02 & 0.13 & 0.01 & 0.01 & 0.01 & 574.1 & i. 776 & 8.924 & -0.1264 & -3 & 85 \\
\hline NN $193-3$ & 45.3 & 0.13 & 0.16 & 0.01 & $0.0 \varepsilon$ & 0.01 & 593.2 & 9.033 & मे. $\Psi 0 E$ & -0.1031 & -3 & $\overline{35}$ \\
\hline
\end{tabular}

SAMFLE \#

tQA tNK(F) TNK(T) tMe(d) tNL(c) tL(d) $t L(c)$

NNM93-1

'C 135

90

$\infty$

(2)

oc

2

$94 \quad 116$

312

IE1

NNM 3 -3

137

s

239

117

18

18

tha
oc
141
154
144

$\begin{array}{rrr}\text { tKM } & \text { tNKC13 } & \text { tNKC 43 } \\ \circ C & \circ C & \text { of } \\ 113 & 138 & 127 \\ 126 & 141 & 131 \\ 120 & 141 & 132\end{array}$


Analyses for chloride were also performed in the UWC laboratory. These analyses are reported in Table 9, alang with LANL analyses performed on samples collected at the same time. Conductivity and $\mathrm{pH}$ measurements conducted in the field were found to be erroneous, as indicated above, and are therefore not reported.

Table 9: Chloride analyses performed at laboratories of LAM and UWC

\begin{tabular}{|c|c|c|c|c|c|}
\hline \multirow[b]{2}{*}{ Date } & \multirow[b]{2}{*}{ Sample } & \multirow[b]{2}{*}{ Location } & \multicolumn{2}{|c|}{ Analysis for $\left[\mathrm{Cl}^{-}\right] / \mathrm{ppm}$} & \multirow[b]{2}{*}{$\underline{\mathrm{pH}}$} \\
\hline & & & UWC & LANL & \\
\hline \multirow[t]{5}{*}{$6 / 27 / 94$} & 6 & Eath house & 137 & & \\
\hline & 7 & River above springs & 15 & & \\
\hline & 8 & River at power house & 14 & & \\
\hline & 9 & River atove springs & $2+1$ & & \\
\hline & 10 & River at power house & $6+3$ & & \\
\hline \multirow[t]{3}{*}{$7 / 1 / 94$} & $11=15$ & River atove springs & $6+1$ & 7.32 & \\
\hline & $12=14$ & River at power house & $50+2$ & 52.4 & \\
\hline & $13=16$ & Bath House spring & $141 \pm 1$ & 150 & \\
\hline \multirow[t]{3}{*}{$78 / 94$} & 19 & River atove springs & $5 \pm 1$ & & \\
\hline & 20 & River at pawer house & $56 \pm 1$ & & 9. \\
\hline & 21 & Bath house spring & $141 \pm 1$ & & 9. \\
\hline \multirow[t]{3}{*}{$7 / 12 / 94$} & 22 & River at power house & $64 \pm 3$ & & $9:$ \\
\hline & 23 & River above springs & $7 \pm 1$ & & 9.7 \\
\hline & 24 & Eath house spring & $141 \pm 1$ & & 9.5 \\
\hline \multirow[t]{3}{*}{$7 / 19 / 94$} & 31 & River above springs & $10+2$ & 9.46 & 8.6 \\
\hline & 32 & River at power house & $69^{*}$ & 65 & 8.6 \\
\hline & 33 & Bath house spring & $129 \pm 1^{* * *}$ & 155 & 9.1 \\
\hline
\end{tabular}

* Analysis done eight days later using new titrant cartridge

** Last analysis with old titrant cartridge

Argentometric titrations were performed on sample UWC94-33 (unfiltered). Different volumes were diluted to $50 \mathrm{~cm}^{3}$ and titrated with $001410 \mathrm{M} \mathrm{AgNO}_{3}$. Results are given in Table 10. Analysis of this somple by LANL showed a chloride concentation of $155 \mathrm{ppm}$. Analyses of samples UWC94-34 and UWC94-34R showed no significant difference between raw and filtered samples. The entries for chloride concentrations in $50 \mathrm{~cm}^{3}$ refer to the concentrations after dilution of the originsl sample, using the 


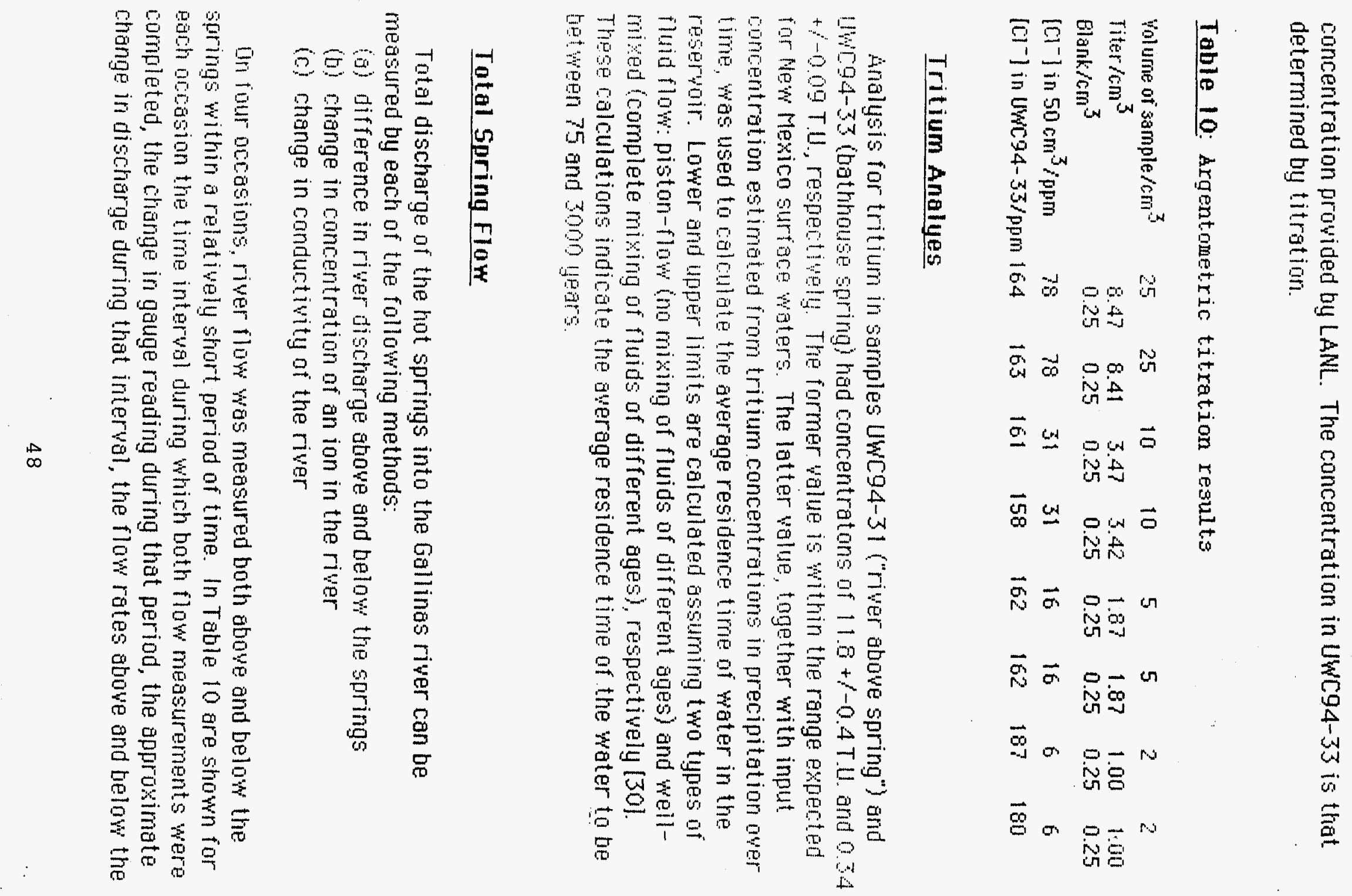


springs, and the difference between them, which should be the total discharge of the hot springs.

Table 11: Total hot springs discharge estimated by difference in river discharges above and below the springs (locations F2 and F3)

Discharue $\mathrm{m}^{3} \mathrm{~min}-1$

Date Lacations Time/hr min Gauge readings/cm Change River (bo. F3) River (loc. F2) Difference

$\begin{array}{rllllllr}7 / 18 & F 3, F 2 & 13: 20-15: 30 & 30.0-19.8 & 6.07 & 2.67 & 4.94 & -2.27 \\ 7 / 19 & F 3, F 1 & 15: 20-17.00 & 18.8-18.8 & 0 & 0.76 & 0.44 & 0.32 \\ 7 / 21 & F 3, F 2 & 13: 10-14: 40 & 36.7-31.5 & 8.35 & 4.18 & 7.33 & -3.15 \\ 7 / 26 & F 3, F 2 & 10: 10-11.46 & 35.7-34.8 & 1.52 & 12.15 & 13.21 & -1.06\end{array}$

For $7 / 21$. the gauge readings were ubtained from Figure 4 . For $7 / 16$ and $7 / 26$ the readings were attained by linear extropolotion of pairs of readings for a shorter portion of the time interval. The fifth column gives the change in river discharge corresponding to the change in gauge readings during the time interval, read from Figures 5 and 6 . The measured discharges appear in columns 6 and 7 and their difference in column 7 . The value is positive only on $7 / 19$, when there was no change in the gauge readings during the measurement interval.

On seven different days samples from appropriate locotions were taken for anslysis by LANL and/or UWC laboratories, and rate of flow or gauge readings above the springs were determined. Using only chloride cuncentration, the rate of flow of the springs can be calculated according to equation 1. In Table 12 are shown the relevant data. Column 2 is calculated from data in Tables 6 and 8 . Column 3 gives the discharge in the river above the springs $\left(V_{i}\right)$. The figures in parentheses were not measured directly but were calculated from gouge readings using Figures 5 and 6 . Discharge from the springs is calculated by multiplying column 3 by column 2. Only on $7 / 19$ was the gauge reading fairly constant. It did not change during the flow messurements, and incressed by $0.2 \mathrm{~cm}$ at the power house between the end of the flow measurements and completion of sample collection. Na information is availatile concerning gauge readings on $6 / 22$. Only a single gauge reading was taken on $7 / 13$, approximately hali-way through the twohour collection procedure. On all other days, gauge readings for a time approximately halfway through the sample collection period were made by extropolating readings obtained earlier, assuming that the rate of change of flow of the river remained constant during the time interval in question. 
UWC data are not included for $7 / 19$, as switching from one titrant cartridge to another gave different results.

Table 12: Total hot springs discharge estimated by dilution of chloride ion entering the river

Date Conc. factor* Analusis Discharqe $\left(Y_{1}\right) / \mathrm{m}^{3} \mathrm{~min}^{-1}$ Sprinus discharge $\left(Y_{8}\right) / \mathrm{m}^{3} \mathrm{~min}^{-1}$

\begin{tabular}{|c|c|c|c|c|}
\hline $6 / 22 / 94$ & 0.148 & LANL & 32.0 & 4.75 \\
\hline $6 / 27 / 94$ & 0.3 & UWC & 12 & 3.8 \\
\hline $7 / 1 / 94$ & 0.46 & LANL & $(0.57)$ & 0.26 \\
\hline $7 / 1 / 94$ & 0.48 & IWC & $0.57)$ & 0.27 \\
\hline 718194 & 0.60 & Who & $(0.30)$ & 910 \\
\hline $7 / 12 / 94$ & 0.74 & IW: & $(023)$ & 017 \\
\hline 719394 & 0.270 & LAMNL & $(1.14)$ & 0.51 \\
\hline $7 / 19 / 94$ & 0.630 & LANL & 0.44 & 0.28 \\
\hline
\end{tabular}

$\left.*=\left(c_{f}-c_{i}\right) / c_{s}-C_{f}\right)$ from equation 1

Cunsidering the uncertainty in flow changes, the data for $7 / 19$ seem the most promising, since it is known that the discharge changed very little during the time of flow messurement and sample collection. Calculations of totai spring discharge can be performed using other ions which are present in the springs in substantial concentration. The results for the most common substances are given in Table 13. Carbonate and hydrogencarbonate ions were not used because their concentrgtions in diferent samples from the springs show more variation than those of the other ions. Analyses were conducted at LANL.

Table 13: Total hot springs discharge on $7 / 19 / 94$ estimated by dilution of various substances entering the river

Chemical Species Cancentration in springs/pom Discharge $/ \mathrm{m}^{3} \mathrm{~min}^{-1}$

chloride ion

fluoride ian

sulfate ion

sodium ion

silicon
155

21.3

40.5

185

32.6
0.28

0.28

0.38

0.36

0.27 
Conductivity measurements; performed in the field and at LANL, can be used to calculate total spring discharge, as has been shown above for specific ions. These data appear in Table 14. UWC analyses performed before $7 / 19$ are not included because internal temperature compensaton of the meter was found to be unreliable

Table 14: Total hot springs discharge estimated by changes in conductivity

\section{Donductivituimicromnos $\mathrm{cm}^{-2}$}

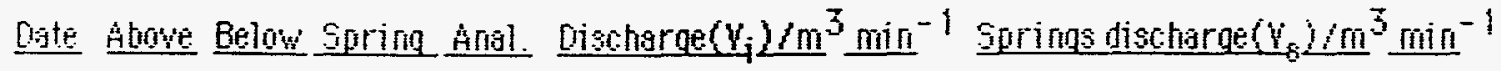

$\begin{array}{lllllll}6122 & 212 & 221 & 970 & \text { LANL } & 32.0 & 3.80 \\ 711 & 312 & 492 & 962 & \text { LANL } & (0.57) & 0.28 \\ 712 & 307 & 420 & 060 & \text { LANL } & (0.95) & 0.24 \\ 719 & 315 & 585 & 965 & \text { WWC } & 0.44 & 0.43 \\ 719 & 312 & 555 & 973 & \text { LANL } & 0.44 & 0.34\end{array}$




\section{Dissolyed Oxygen, Biological Oxygen Demand, and Bacteria}

The results of tests for discolved oxygen at different locations and times are shown in Figure 20.

Figure 20: Dissolved oxygen. sanpled at 8:00-9:00 a.il. and 4:005:00 p.in. at different locations

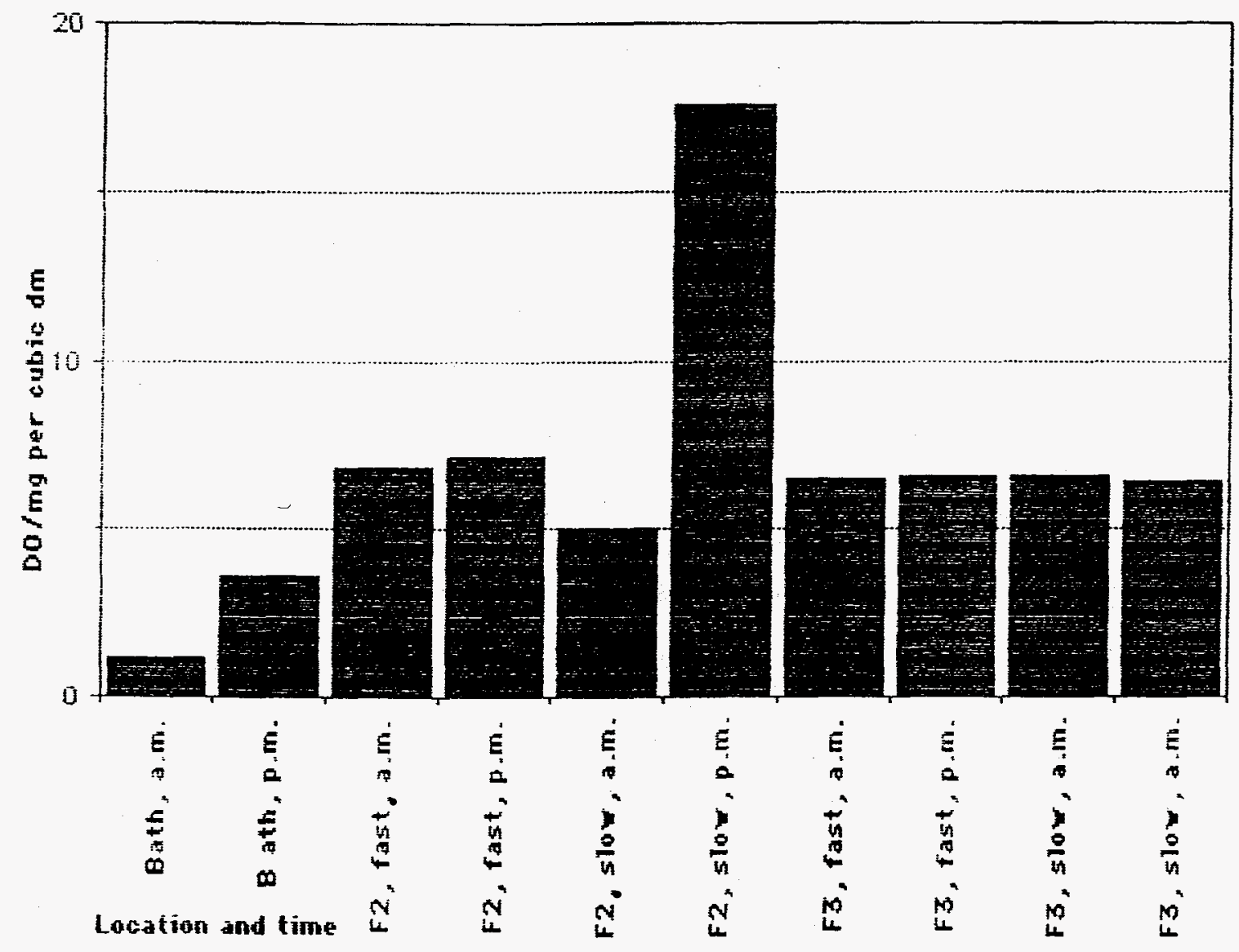

The amount of bo found in the hot bath at both times was below that considered necessary for most organisms, but it increased three-fold during the day $\left(1.2 \mathrm{to} 3.6 \mathrm{mg} \mathrm{dm^{-3 }}\right)$. This was most likely due to the algae grawing on the sides of the enclosure; species found are discussed below. This value for Do is not extremely low considering the temperature of the water. At $40^{\circ} \mathrm{C}$ and one atm pressure the solutility of oxygen in water is $6.6 \mathrm{mg} \mathrm{Jm}^{-3}$. At the normal lacal atmospheric pressure of about $560 \mathrm{~mm} \mathrm{Hg}$, the solubility would be $5.0 \mathrm{mg} \mathrm{dm}^{-3}$. The samples taken at location F2 in the flowing part of the river increased from 6.8 to $7.2 \mathrm{mg} \mathrm{dm}^{-3}$ during the doy 
(67 to $82 \%$ saturation, corrected for elevation) and those from the slower part went irom 5.0 to $17.6 \mathrm{mg} \mathrm{dm}^{-3}$ (47 to over $100 \mathrm{~g}$ saturation.). This increase was due to the fact that these samples were taken near a small patch of algae and show the importance of photosynthetic species to the overall health of the river. For the samples from lacation F3, beloy the springs, the samples from the flowing part of the river went from 6.5 to 6.6 $m g \mathrm{dm}^{-3}$ (83 to 698 saturation due to the temperature chonge) and in the slow area (quite stagnant) from 6.6 to $6.4 \mathrm{mg} \mathrm{dm}^{-3}$ (75 to $78 \%$ saturation.). There was a temperature difference at these two sites of $10^{\circ} \mathrm{C}$ in the morning and only $45^{\circ} \mathrm{C}$ in the afternoon.

The oxygen electrode was available after the above tests had been run. It was compared to the test kit using a common sample, and gove a reading of $6.6 .5 \mathrm{mg} \mathrm{dm} \mathrm{m}^{-3}$. The test kit measured $72 \mathrm{mg} \mathrm{dm}^{-3}$, suggesting that results of earlier detarminations are about $1.4 \mathrm{mg} \mathrm{m} \mathrm{dm}^{-3}$ low. On August 12 . 1994. samples were taken from 1000 to 11.00 a.m. for Do and Boo determmations, with the results indicated below:

\begin{tabular}{|c|c|c|c|c|c|}
\hline & Date & Eath & $\mathrm{F} 2$ & $\mathrm{F3}$ & Mid-river \\
\hline $00 / \mathrm{mg} \mathrm{dm}^{-3}$ & $\begin{array}{l}8 / 12 / 94 \\
8 / 17 / 94\end{array}$ & $\begin{array}{l}1.5 \\
0.27\end{array}$ & $\begin{array}{l}8.65 \\
600\end{array}$ & $\begin{array}{l}8.75 \\
5.56\end{array}$ & $\begin{array}{l}8.7 \\
5.56\end{array}$ \\
\hline $\begin{array}{l}\text { Boo/mg dm } \\
8 \text { avallable oxygen }\end{array}$ & $8 / 12 / 94$ & 1.23 & 2.65 & 2.65 & 3.14 \\
\hline utilized by bacteria & & 82 & 31 & 31 & 37 \\
\hline
\end{tabular}

Biological oxygen demand (Boo) is a measure of the activity of bacteria, mainly decompusers. of greater interest than the actual numbers is the relative proportion of avalable oxygen used by the bacteria over the five days. The results shom above indicate significant actioity in the hut springs water. The water samples were incubated at $20^{\circ} \mathrm{C}$ for the five days, so temperature is not considered a factor.

Bacteria cultures run with water collected from these lacations an July 19 also indicated the presence of bacteria in the hat springs. The cutures from the hot bath had three colonies of Coliform and one small colony of $E$. cal None of the other cultures contained sny Coliform bacteria. Coliform bacteria are indicators of fecal material from warm-blooded organisms. E. 
coli is specific for human waste since this is the species found normally in the large intestine. A second test from the hot springs done on. July 21 did not show any $E . c o l i$, but did have two colonies of unidentified Coliform bacteria.

\section{Plant and Algae Species}

Species found in the river included sprogurs shs. (two or three species of different sizes) which is a common green algae in fresh water. This was the species in the patch of algae near which the Do water sample was taken on July 19. This patch was gone an August 12, probably due to high water and silt deposits. Mast of the algae had also disappeared from the rocks in this ares. There was one small patch of Elades (a communon macrophyte) about $1.5 \mathrm{~m}$ further down stream. other species found were Fatomogetoh nectingtws and numerous distom shs Diatoms are commonly classified as Golden Algae and require silica for their outer testa (shells). Camman species frund along the banks include emergents: Elocons solhts thericonis, other reds and rushes, Equsetw and numerous grasses. Russian ulive, an exatic species, is beginning to crowd out some of the native species, especially the willows. None of the species found in the river or an the banks (except the Russian olive) are considered nuisance or unitanted species.

The dominant species found in the springs themselves is the blue-green (Cjanobacteria) aschlotora sas along with numerous rotifers (Frotista) Wo species that have been classified as thermophiles (hot water species) were identified, probatly because they dominate arese at temperatures claser to $60^{\circ} \mathrm{C}$, while these springs have temperatures of 40 to $54^{\circ} \mathrm{C}$. A more extensive study of the species from all the springs might reveal some of these thermophiles.

The species that are now called cyanobacteria were classified as Bluegreen Algae for many years untii it was determined that, because of their internal cellular structure, they were prokaryotes and, therefore, Monera alung with the rest of the bacteria. This has led tu a great deal uf confusion and conflict aver names and descriptions used by bacteriolagists vs botanicts and athers interested in squatic species and water quality indicators.

The totanical, ascilstaris ans is used in this report. These species can survive with oxygen or at low oxygen levels. Cyanobacteria (blue-greens) are found in wirtually every ecosystem, because many of them are capable of 
fixing nitrogen and so can live in waters that are very low in nitrogen. Some, but not all, can become nuisance species giving water sources a bad taste and noxious odor. Since they are photosynthetic they add to the on of the water unless they become overly abundant and die off; then their decomposition can lead to anoxic conditions. Those found in the hot springs are not so abundant and add to the 00 cantent of the springs.

\section{DISCUSSION}

\section{Sampling and Measuring Locations}

The bathhouse spring (*1) is the best of the hot springs for sampling and measurements. It forms a "well" about 5.2 meters deep with a harrow circular opening about 40 crn atove ground level and above water level. Samples were taken from an overflow pipe, and the flow is the greatest of and of the springs. Since this spring is nut used for bathing and is out of sight from those used by the public, the possibility of human use affecting the spring is minimal.

Sampling at the central soring (*6) was made at the rear af a cuncrete trough partially covered by a cuncrete slat. The hot water seems to emerge in this ares. The trough feeds two baths which receive considerable use rom the public, members of which occasionally throw trash into the trough. Flow was measured occasionally at the overflow from the last bath.

The seep emerges directly from the ground with sufficient flow that samples can be obtained with relative ease.

St. Michaels spring ( 13 ) has the second greatest rate of flow and is the most popular of the springs. The water enters the bottom of a concretelined cylinder which is abuut 1.5 meters deep and 1.5 meters in diameter. An overflow pipe frum this top bath was used to measure flow. This spring was not sampled for chemical analysis because the top reservair is used frequently for bathing.

Selection of locations for stage measurements proved difficult. A favorable site would be one with an even, regular stream bottom, clearly 
defined edges, and an even flow of woter parallel to the sides. The Gallinas River meanders, changes in width from $30 \mathrm{~cm}$ to 6 meters in short stretches, and is liberally strewn with rocks and boulders. Location F2 proved very convenient for measurements at relatively high rates of flow, but was sufficiently wide and deep that flow could not be measured at lower stages. The nearest location for low flow was undesirably far upstream, raising the possibility that water may enter the river between these twa lacations. It has not been possible to gather enough data to evaluate this situation. Location F3 proved reasonably satisfactory under conditions of low and moderate discharge. Location F4 was tested once, as appearing more favarable for very low flow than locstion F3. Temperature and conductivity messurements at the two locations indicated s substantial inflow of cold water with low ion concentrations between the two lacations. Efforts to use conductivity messurements to lacote the source of the water were interrupted by bad weather and could not be resumed when river discharge increased. Later exploration of this section of river revealed two cold-water inlets.

\section{River Flow}

Que to rapidy changing river stage throughaut the period of measurements, it was never possitie ta repeat a discharge measurement at the same stage value in order to determine the reproductibity of the procedure under prevailing conditions. The fact that using half a set of measurements gave results very close to those ottaned from the complete set of measurements (Table 2) suggests good renroducitility, as do good fits to second-order equations for plots of river discharge against stage (Figures 5-7). These apparently good fits may be more coincidental than real, for three reasons. Relatively few data points could be obtained, especially for locations F1 and F3. A second problem is that plots of crosssectional area and average velocity against stage do nat shaw as good a fit to second-order equations (Figures 8-13). Especielly for location F2, where seven data points exist, the correlations for stage against cross-sectional area $\left(R^{2}=0.041\right)$ and average velocity $\left(R^{2}=0.983\right)$ are appreciably inferior to that against total discharge $\left(R^{2}=0.992\right)$. It appears that errors in ares and velacity might cancel each ather out when used to calculate discharge. Finally, the appropriate equation far the rating curve might not be 


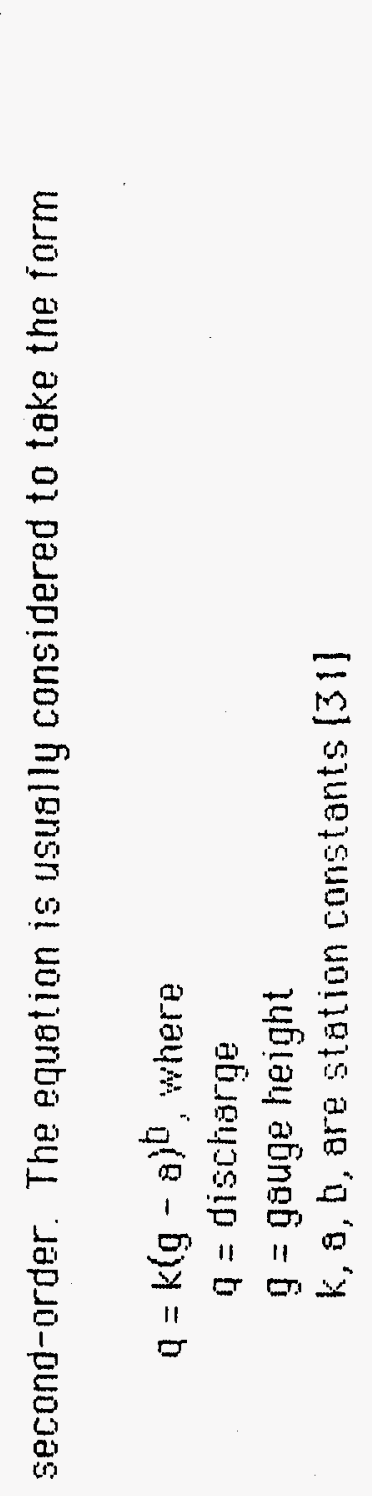

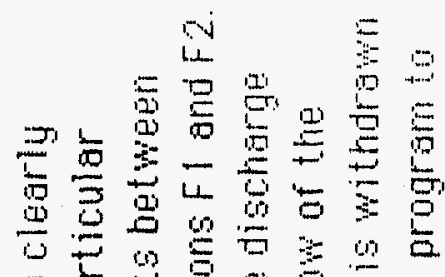

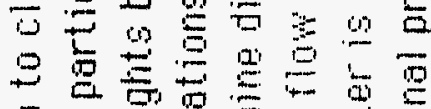

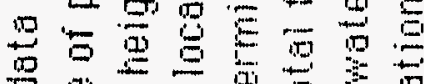

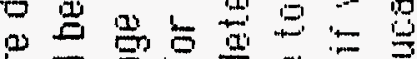

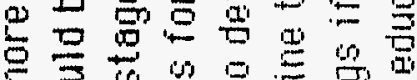

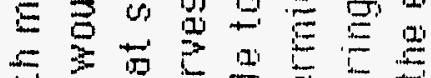

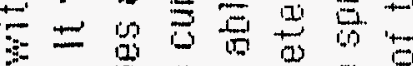

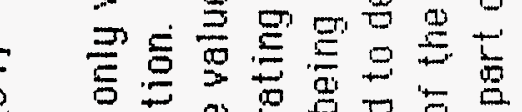

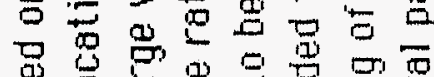

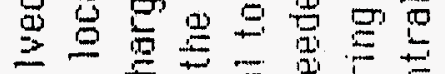

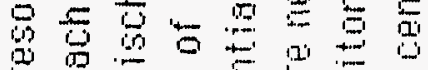

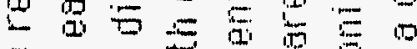

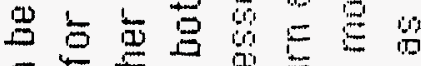

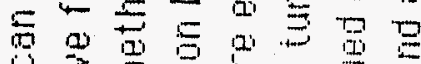
65

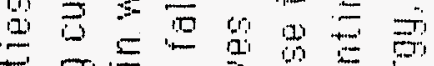

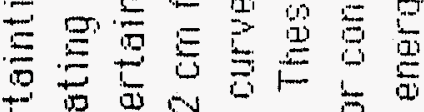

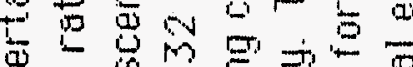

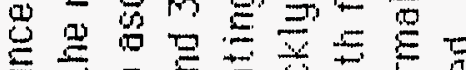

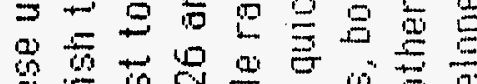

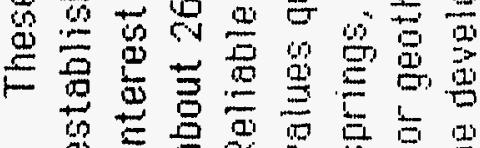

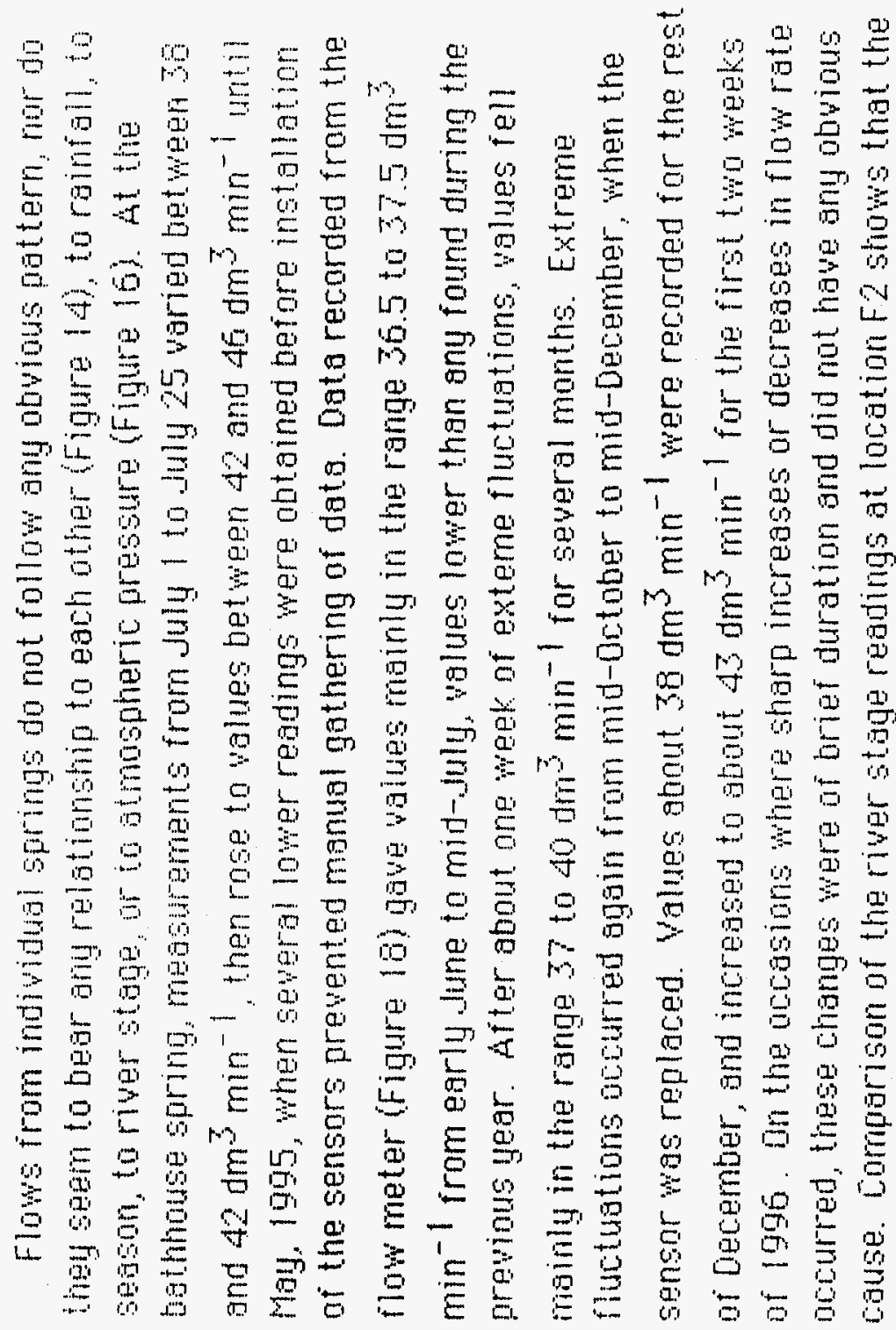


stage was low from the end of June until July 19. On July 21 it increased greatly, then dropped a great deal during the day. From July 26 onwards the stage was appreciably higher due to frequent rains. This was about the some time that the bathhouse spring flow increased. Short-term fluctuations in stage due to individual storms did not seem to affect the flow of the spring.

At St. Michael's spring the discharges fall into the narrow range of 14 to $16 \mathrm{dm}^{3} \mathrm{~min}^{-1}$ exrept for decreases when members of the local community empty and clean the top reservoir. Recovery to the previous flow rate takes about one week. There seems to be no relationship between changes in flow of the two springs (Figure 14)

Previous records of spring discharge are not consistent. Road construction and repair and re-routing of springs could cause substantial changes over tirne. From a high value of $21 \mathrm{gam}\left(60 \mathrm{dm}^{3} \mathrm{~min}^{-1}\right)$ in 1685 . maximum individual spring flowe decreased to 5 and $5.8 \mathrm{gprn}\left(19\right.$ and $22 \mathrm{dm}^{3}$ $\mathrm{min}^{-1}$ ) in 1952 and 1966, respectively. Values obtained in the summer of 1993 for the bathhouse and st Michaels springs are both neaily $30 \%$ higher than the measures in the current study. The measurement method used in l9g3 was not specified [11]

\section{Temperature}

Almost all temperature measurements at the bothhouse spring are within the range of $54-55^{\circ} \mathrm{C}$ (Figure 15 ), and show no pattern of fluctuation over one year. This agrees with nther readings taken since 1940. Measurements taken in the last century were $10^{\circ} \mathrm{C}$ higher, but Summers [32], in a survey of thermal waters in New Mexico, notes that available temperature, flow, and chemical data are of ten inaccurate and incomplete. Data recorded with a thermocouple from May, 1995, show many extreme peaks exceeding $66^{\circ} \mathrm{C}$, and can not be considered reliable (Figure 19). The temperature of st. Michael's spring was monitored from a later time and varied over a slightly wider, but lower, range of $47-49^{\circ} \mathrm{C}$ until mid-0ctober, when temperatures gradually decreased to about $45.5^{\circ} \mathrm{C}$ during the winter months. A daily pattern was also seen; during the summer temperatures were generally 
below $57.9^{\circ} \mathrm{C}$ in the morning and above that value in the afternoon. The change can be about $1^{\circ} \mathrm{C}$ during the day (see data for $8 / 12$ and $8 / 16$ in Table 5). This seemed unaf fected by emptying the top reservoir on $8 / 14$. On several accasions, when the top reservoir seemed not to have been used for a period of time, measurements were made at the top (about $15 \mathrm{~cm}$ below the surface) and bottom of the reservoir with the maximum reading thermometer. oifferences were usually undetectable and never exceeded $0.3^{0} \mathrm{C}$. Bubbles of gas continually rising through the water would cause mixing as would convection currents arising fram cooling of the surfoce.

\section{$\mathrm{pH}$ and Conductivity}

Values of ph range from 8.9 to 9.3 , and are similar to volues of $8.4-9.0$ repurted by Summers [33] from US6s analyses from 1952 and 1966. These numbers are sightly below tupical walues for dilute chloride-ticartonate Waters, which usually fall in the range $p H=6-8$ [34]. Conductance values of varius springs tested from $1939-1960$ give values ronging from 810 to 878 micrombe $\mathrm{cm}^{-1}$, similar to the range of values of $831-662$ micrumbe $\mathrm{cm}^{-1}$ found in 1993 and 1994 . No spring was consistently different from the others with respect to either oH or conductivity.

\section{Chemical Analyses}

Complete chemical analyses were done in 1993 and 1994 ty LANL. The 1903 datio are for three different springs sampled on one bccasion. The 1994 tests were done on two of the springs sompled in 1993 plus one new source. These three sources were sampled on three different occasions, and the bathhause spring on two additional accasions, making a total of 11 different spring samples. Camparison of these results with historical values shows remarkable consistency, especially for chloride concentrations. of seven sets of values from 1609 to 1994 , six fall in the range 152-166 ppm. In 1993 the average value was $179 \pm 3$ pam. Sodium ion concentrations are virtually identical in 1966, 1993, and 1994. Fluoride ion has shown no significant change since 1952, except for an anomalous result in 1966. The $510_{2}$ concentration in 1994 wos $66.7 \pm 2.2$ ppm, similar to results dating back to 1682 . In Table 15 are given results for analyses of 
various ions and their ratios in the springs in 1993 and 1994 and for the river above the springs in 1994. These data may be used to answer questions about a common origin for the springs and for the relstion of the river to the springs.

Table 15: Ion concentrations and ion concentration ratios in the hot spring 3 in 1993 and 1994 and the river above the springs in 1994. For each set of analyses are given the number of samples ( $n$ ). the average value, and the standard deviation.

\begin{tabular}{|c|c|c|c|c|c|c|c|c|c|}
\hline & B & Br & $\mathrm{Cl}$ & $c_{s}$ & F & $k$ & $\mathrm{Li}$ & $\mathrm{Na}$ & $\underline{504}$ \\
\hline \multirow[t]{3}{*}{1993 Springs } & $n=3$ & $n=3$ & $n=3$ & $n=3$ & $n=3$ & $n=3$ & $n=3$ & $n=3$ &. \\
\hline & 0.54 & 0.92 & 179 & 0.062 & 22.1 & 5.69 & 0.34 & 174 & 44 \\
\hline & \pm 0.01 & \pm 0.04 & \pm 4 & \pm 0.002 & \pm 0.7 & \pm 0.10 & \pm 002 & \pm 4 & \\
\hline \multirow[t]{3}{*}{19945 prims } & $n=10$ & $n=11$ & $n=11$ & $n=9$ & $\pi=11$ & $n=11$ & $n=11$ & $\pi t=11$ & \\
\hline & 0.52 & 075 & 152 & 0.068 & 20.8 & 597 & 0.34 & 174 & \\
\hline & \pm 0.01 & \pm 0.04 & \pm 3 & \pm 0.004 & \pm 0.7 & \pm 0.27 & \pm 0.06 & \pm 7 & \\
\hline \multirow[t]{3}{*}{1994 River } & $n=3$ & $n=3$ & $n=3$ & & $n=3$ & $n=\bar{s}$ & $n=3$ & $n=3$ & \\
\hline & 0.02 & 0.05 & 7.2 & & 0.49 & 1.17 & 0.01 & 8.4 & \\
\hline & 0.00 & & \pm 2.3 & & \pm 0.13 & \pm 013 & \pm 0.01 & \pm 1.7 & 2.1 \\
\hline
\end{tabular}

$\mathrm{B} / \mathrm{Cl} \quad \mathrm{Br} / \mathrm{Cl} \quad \mathrm{Cs} / \mathrm{Cl} \quad \mathrm{F} / \mathrm{Cl} \quad \mathrm{K} / \mathrm{Cl} \quad \mathrm{Li} / \mathrm{Cl} \quad \mathrm{Na} / \mathrm{Cl} \mathrm{s04/Cl}$

$\begin{array}{lllllllll}1993 \text { Springs } & n=3 & n=3 & n=3 & n=3 & n=3 & n=3 & n=3 & n=3 \\ & 0.0030 & 0.0051 & 0.00035 & 0.124 & 0.03183 & 0.0019 & 0.98 & 0.249 \\ & 0.0001 & 0.0004 & 0.00002 & 0.002 & 0.0006 & 0.0002 & 0.03 & 0.004\end{array}$

19945prings $n=10 \quad n=11 \quad n=9 \quad n=11 \quad n=11 \quad n=11 \quad n=11 \quad n=11$

$\begin{array}{llllllll}0.0034 & 0.0049 & 0.0004 & 0.137 & 0.0393 & 0.0023 & 1.14 & 0.260\end{array}$

$\begin{array}{llllllll}0.0001 & 0.0002 & 0.0001 & 0.002 & 0.0023 & 0.0004 & 0.03 & 0.004\end{array}$

1994 River $\quad n=3 \quad n=1 \quad n=1 \quad n=3 \quad n=3 \quad n=3 \quad n=3 \quad n=3$

$\begin{array}{llllllll}0.0034 & 0.0055 & 0.0005 & 0.069 & 0.172 & 0.0018 & 1.19 & 2.29\end{array}$

$\begin{array}{llllll}0.0010 & 0.006 & 0.050 & 0.0004 & 0.16 & 0.42\end{array}$ 
The chemistry of the different springs is essentially identical, indicating a common origin. These similarities can be seen in the data of Tables 7 and 8 and in the low standard deviations of mast sets of data for the springs in Table 15. This interpretation is reinforced by the consistencies of the ion ratios. The ratios $\mathrm{B} / \mathrm{Cl}, \mathrm{Br} / \mathrm{Cl}$ and $\mathrm{Cs} / \mathrm{Cl}$ are considered especially useful as indicators of a common reservoir source [35] of the eight ratius calculated, in five the standard deviation does not exceed 3.5 of the average value. For the individual ions, in five of nine analyses the standard deviation did not exceed 4 \% of the average value. Most of the values for 1993 and 1994 were within experimental uncertainty (the standard deviation of each value) of each other if the chloride value of 1994 was used in place of that for 1993 . The only ratios not reconcilable in this manner are $\mathrm{F} / \mathrm{Cl}$ and $\mathrm{SO} / \mathrm{Cl}$, tut they do lie within the experimental uncertainty of the method. All three of these ians are determined by ion exchange chromatagraphy, which has an uncertainty of $\pm 5 \%$ for each ion [35]. A ratio of two ions thus has an experimental uncertainty of $\pm 10 \%$. The F/Cl and $\mathrm{SO}_{4} / \mathrm{Cl}$ values are well within that range.

Another interesting comparison is that of ion concentration and ion ratios in the springs and in the river atove the springs. Fiver cuncentrations are al ways lower than those in the springs, but many ion ratios are similar, specifically $\mathrm{B} / \mathrm{Cl}, \mathrm{Er} / \mathrm{Cl}, \mathrm{Cs} / \mathrm{Cl}, \mathrm{Li} / \mathrm{Cl}$ and $\mathrm{Na} / \mathrm{Cl}$. Three ratius are very different in the two situations $-\mathrm{F} / \mathrm{Cl}, \mathrm{K} / \mathrm{Cl}$, and $5 \mathrm{SO}_{4} / \mathrm{Cl}$.

Since these analyses are useful for characterizing the waters of the springs, as well as for calculating total discharge of the springs, preliminary analyses have been attempted in the UWC laboratories and compared to those done by LANL. It appears that chloride analyses using the digital titrator from the Hach kit give satisfactory results (see Table 9 ). The concentration value of the new cartridge is suspect, but if the analysis is used to calculate total discharge, using equation 1, a systematic error in the titration value will not affect the result. Argentametric titrations with a burette gave satisfactory agreement for solutions containing $16 \mathrm{ppm}$ chloride or higher, but not for solutions containing 6 pam. Even for the lowest flow measured, on duly 19, the concentration of chloride in the river atuve the springs was 9 ppm. This method will find only limited use unless it can tie improved to be reliable for lower concentrations. 


\section{Geothermometers}

Calculations have been made in Tables 7 and 8 for several geothermometers. Values pertaining to spring samples only are summarized in Table 16.

Table 16: Temeratures calculated for several geothermometers for spring samples collected in 1993 and 1994.

\begin{tabular}{|c|c|c|c|c|c|c|c|}
\hline Year & Sainple & Location & toc & ton & $\operatorname{tNK}(E)$ & $\operatorname{trk}(\mathrm{T})$ & $\operatorname{tNKC13}$ \\
\hline \multirow[t]{3}{*}{1993} & UnCos-1 & Bäthhouse & 120 & 110 & 135 & 90 & 136 \\
\hline & twhos-2 & St. Michael's & 115 & 114 & 138 & 94 & 141 \\
\hline & wes3-3 & Centra 1 & 115 & 113 & 137 & 92 & 141 \\
\hline \multirow[t]{11}{*}{1994} & IXC94-1 & Ea throuse & 117 & 116 & 132 & 86 & 141 \\
\hline & UWC $94-2$ & Central & $11 \overline{2}$ & 114 & 135 & 90 & 143 \\
\hline & ITIC-5 & Seep & 115 & 114 & 134 & 89 & 141 \\
\hline & IMC $94-16$ & Bathhouse & 119 & 117 & 143 & 99 & 143 \\
\hline & गW0 $94-17$ & Central & 110 & 116 & 144 & 101 & 145 \\
\hline & $7004-18$ & seep & 115 & 114 & 144 & 101 & 143 \\
\hline & 1W0 $94-25$ & Eathoudse & 118 & 116 & 143 & 99 & 143 \\
\hline & TWT $-94-26$ & Seep & $11 E$ & 114 & 145 & 18 & 143 \\
\hline & $1604-27$ & Central & 116 & 116 & 141 & 9 & 15 \\
\hline & 1ाT $94-3$ & Ba thhouse & 110 & 116 & 137 & 3 & 142 \\
\hline & MOव4-34 & Bathhouse & 120 & 118 & 140 & 95 & 143 \\
\hline
\end{tabular}

Shica geothermometers rely on asolute concentrations rather than on ratios, and these can be changed by physical processes such as boiling and dilution [37]. The Montezuma Hat Springs do not produce steam, and if difution occurred, it would produce a low value for the temperature. A high yolue could be caused by mixing with acidic waters near the surface. This event is unlikely to be important since both spring and surface waters are slightly basic. other geothermometers may be even less rehatle. The Na-K geothermometer relations tend to break down below $120^{\circ} \mathrm{C}$ and $/$ or where lateral flow gllows reactions near the surface [38]. The calcium concentration is tou luw for use of the $\mathrm{Na}$ - K-Ca geothermometer [39]. Two general indicators suggest that solute geothermometers may not be appropriate for these hot springs. Conductive cooling is indicated by low 
flow rate ( $\left.<30 \mathrm{dm}^{3} \mathrm{~min}^{-1}\right)$ and groups of springs with similar chlaride concentrations but different temperatures [40]. A high $\mathrm{Na} / \mathrm{K}$ value $(>15 / 1)$ indicates lateral flow, conductive cooling, and near-surface reactions [41]. Both of these conditions apply to the Montezuma springs, rendering them unsuitable for solute geothermometry because of the possibility of rockwater interactions as the water nears the surface, thus changing the original composition. The most that can be concluded from geothermometer data is that the temperature of the reservoir is greater than $115^{\circ} \mathrm{C}$.

\section{Tatal Springs Discharge}

When discharges are measured both above and below the springs, the difference should be the discharge of the springs. on the four occasions when these data are available, three sets of data give substantial negative values (Table 11) In all three of these coses the river stage fell substantially during the time of measurement. on $7 / 21$, when a continuous record of stage vs time was avallable, converting stake readings to gauge readinģs (Figure 4 ) and determining discharge measurements from Figures 6 and 7 gave the following results, compared to the measured discharge values:

\begin{tabular}{|c|c|c|c|}
\hline & Locotion $\mathrm{F} 3 / \mathrm{m}^{3} \mathrm{~min}^{-1}$ & Location F2/dm ${ }^{3} \min ^{-1}$ & Difference $/ \mathrm{mm}^{3} \mathrm{~min}^{-1}$ \\
\hline M & 418 & 7.33 & -3.15 \\
\hline ed & 456 & 486 & -0.30 \\
\hline
\end{tabular}

Only on $7 / 19$ was a positive difference obtained, as a result of two favorable conditions. The stage remained constant during both flow measurements, and it was the lowest value measured during the summer. This low stage insured that discharge of the springs made a significant contribution to the river. If the spring discharge were $0.32 \mathrm{~m}^{3} \mathrm{~min}^{-1}$ the value obtained on $7 / 19$ ) and the river discharge were over $3.2 \mathrm{~m}^{3} \mathrm{~min}^{-1}$, the spring discharge would be less than $10 \%$ of the total river discharge. If the uncertainty of discharge measurements at two locations were each $\pm 5 \%$, the difference due to the springs could be more than $50 \%$ greater than the actual value, or less than half of it only on $7 / 19$ were river discharge values telow $3.2 \mathrm{~m}^{3} \mathrm{~min}^{-1}$ at location $\mathrm{F} 1$ or $\mathrm{F} 2$ and discharge values determined also at location $F 3$. This method also requires a constant value of the gage 
resding for any conclusions to be reliable. If the average velocity of the stream is $3.5 \mathrm{~m} \mathrm{~min}^{-1}$ at $F$ ( (see Table 5 for 7/19/94), with an approximate distance of $900 \mathrm{~m}$ from Fl to $\mathrm{F} 3$. Water at the upper site would take over three hours to reach the lower site. This estimate assumes that the average velocity at $F 1$ approximates the sverage value for the entire stream between $\mathrm{Fl}$ and $\mathrm{F3}$. The average velocity for the entire stream is probably less than that at $\mathrm{Fl}$, because the site was chosen to give a megsurable velocity at low flow. Comparing average velocities at $F 1$ and $F 2$ on $7 / 31$, when the stage readings were similar (see Table 5), the average velocity was much greater at $F 1$ than at F2.

This combination of low flow and constant gage readings is rarely achieved during the summer. Thus it has limited application. This method was used by the U. 5 Geological Survey in 1966 [42], and gave a total spring discharge value of 325 gprn $\left(1.23 \mathrm{~m}^{3} \mathrm{~min}^{-1}\right)$, tut the downstream reading was taken beyond location $F 4$, so is rendered invalid by the fact that cold water enters the stream between hoctions $F 3$ and $F 4$.

Estimation of total spring diccharge based on ion dilution shows considerable variation. Most andiyese were based on choride ion. Tabie 12 shows that calculated discharges on seven different occosions ranged from $0.17 \mathrm{~m}^{3} \mathrm{~min}^{-1}$ to $4.75 \mathrm{~m}^{3} \mathrm{~min}^{-1}$. Two values of 3.8 or more $\mathrm{m}^{3} \mathrm{~min}^{-1}$ were were at least ten times higher than any of tho other values, and were obtained at reliatively high river discharge values. of the six other values, ranging from 0.17 to $0.31 \mathrm{~m}^{3} \mathrm{~min}^{-1}$, only one was obtained with a measured rather than with an estimated river diccharge value. This value of $0.28 \mathrm{~m}^{3}$ $\mathrm{min}^{-1}$ was obtained on July 19 when the stage did not change, and a discharge value of $0.32 \mathrm{~m}^{3} \mathrm{~min}^{-1}$ was found as the difference between rates of river flow sbove and below the springs. The dilution of other ions on that same day were also used to estimate the total discharge (Table 13). These values range from 0.27 to $0.36 \mathrm{~m}^{3} \mathrm{~min}^{-1}$.

Table 14 gives conductivity measurements which can slso be used to estimate total spring discharge. The three sets of measurements by LANL at low flow rates should be the most reliable; the results range from 0.24 to $034 \mathrm{~m}^{3} \mathrm{~min}^{-1}$. The highest value of these was otitained on July 19.

Consideration of the data for total discharge suggest that the actual 
value probably lies in the range 0.27 to $0.34 \mathrm{~m}^{3} \mathrm{~min}^{-1}(70-90 \mathrm{gpm})$. This conclusion relies entirely on results from the one day when conditions were favorable for obtaining reliable data, but is supported by evidence from seven different sets of measurements. It is essential to obtain reliable rating curves so that estimates of flow rate can be made from stage measurements within a few minutes, and samples for ion analysis can be drawn at the same time, on those occosions when the level of the river remains constant for a few hours. 


\section{ACKNOWLEDGEMENTS}

Support for this work was provided by Los Alamos National Laboratory, through the affices of Abad Sandoval and David Duchane, to whom we express our sincere gratitude. We are also grateful to Dale Counce of LANL for the chemical analyses and a great variety of ather help, and to Fraser Goff for arranging for tritium analyses as well as providing a stimulating day in the field looking at the geology of hot springs. 


\section{REFERENCES}

1. Reinerts, T.H., A History of the Montezuma Hot Springs, Hotels, and Bathhouses, 1849-1937, M.S. Thesis, New Mexico Highlands University. 1966.

2. US.A. vS Hope Community Ditch, et al., Couse No. 712 Equity dd/May 8 , 1933

3. New Mexico State Engineer, Pecos River Stream System Hydrographic: Survey Report Gallinas River Section. Vol 1, Santa Fe, June, 1991.

4. Hoyden, F Y (1869), quoted by Summers, WK. A Catalog of Thermal Waters in New Mexicn Hydrologic Feport 4, New Mexico Eureau of Mines and Mineral Resources, Socorro, 1976 , p. 69

5. Stevenson, 1.1 (1801), quoted by Summers, op. cit., p. 69

6. Management The Climate of New Mexico and Las Vegas Hot Springs Foole Bros, Frinters, Chicago, 1885.

7. Crook, IK (1899), quoted by Summers, op cit., p. 69 .

8. United States Geological Survey (1966) data reported by Summers; op cit . . 70.7

9. Ibid. P. 72 .

10. United States Geological Survey (1952), data quoted by Summers, op. cit., p. 69

11. Nickersan, M.D., "Mantezuma Hot Springs -- The Armand Hammer United World College: A Geothermal Feasibility Study", report prepared at Los Alamos National Laboratory. 1993.

12. United States Geological Survey (1960), data reported by Summers, op. cit., p. 69

13. United States Geological Survey (1966), data reported by Summers, op. 


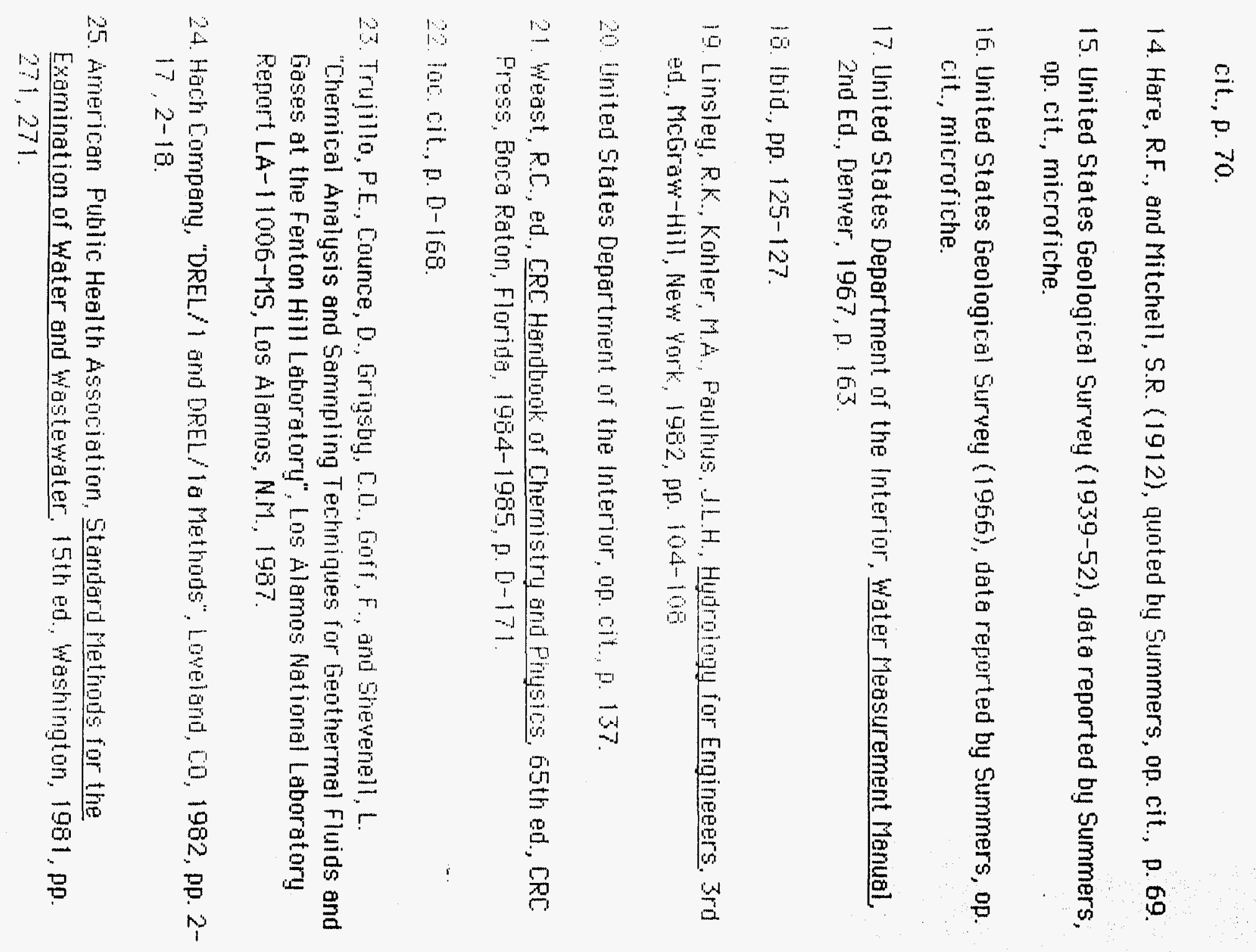


26. Vogel. A.1. A Textbook of Quantitative Inorganic Analysis Including Elementary Instrumental Analysis, ELBS ed., Longmans, London, 1962, p. 259.

27. Calculated from data in Lange. N.A., Handbook of Chemistry. Rev. 10th ed. McGraw-Hill, New York, 1967, p. 1101.

20. Linsley, et al., loc, cit., ,1. 106.

29. Nicholson, K., Geothermal Fluids Chemistry and Exploration Techniques. Springer-Verlag, Heidelterg, 1993, a. 50.

30. Shevenell. L. "Tritium in the thermal waters discharging in Loowit Canuon, Mount st Helens, Wghington, USA.", Chem Geol Isotoge Geoscience section) $94(19911,123-135$.

31. Lifsey, et al op cit pp. $110-111$

32. Summers, wK. Chemical Characteristics of New Mexico's Thermal Waters - A Critique Circular 83 , State Boand of Mines and Mineral Resources. New Mexico institute of Mining and Technoiogy, Socorro. 1965 , p. 24-26.

33. United States Geological Surveg (1952 and 1966), data reported by Gumbets (1976), op cit. pip 70,71 , microfiche.

34. Nicholson op. cit., pp. $23-20$

35. Ibid., p. 50

36. Watson, I.H.C., "Sampling and Analysis Methods for Geothermal Fluids and Gases" Facific Northiest Latoratory Report PNL-MA-572, Richland. WA, 1976, pp. $[-60,94,205$.

37. Nichoison, 00. cit, , 90

36. Itiid., f. 45

39. Lid., p. 73 
40. Ibid., p. 35.

41. Itid., p. 45.

42. United States Geological Survey (1966), data quated by Summers (1976), ap. cit., p. 69 . 


\section{ATTACHMENT E}

The Hot Springs

at

Montezuma, New Mexico

Science Education Materials for Students

Section 5 


\section{Introduction}

Before recorded history, the Montezuma hot springs were used by Indians for therapeutic purposes. The legend of their use by the Aztec chief Montezuma, and hence their current name, was propagated by Indians. The legend may be true, or it might have been used to appease or confuse the white man. During the Civil War the Union army used the springs for convalescence of wounded soldiers. Local wamen made extensive use of the springs for washing clothes. In the latter half of the igth century the property changed hands numerous times, for increasing sums of money. Small hotels, then larger, were built by various entrepreneurs to capitalize on the presence of the springs. Several bethhouses were built. The last major one was destroyed in a flood in 1904. About the same time the third large Montezuma Hotel, having become unprofitable, was closed and the tourist era ended in Montezuma. The hotel and property had several reincarnations as a Baptist college and Mexican Catholic lesuit seminary. it is presentiy part of The Armand Hammer united World College of the American west. The old tourist hotel is currently not in use due to structural damage although the college has plans to historically preserve and reuse the facility. The buildings occupied by the college include an older stone hotel built in 1880 and others built during the time of the seminary.

The present heating system for the coliege utilizes hot water produced by a coal-fired boiler. To reduce pollution and heating costs from the burning of coal, the college has started to investigate the possibility of using the energy of the hot woter coming up into the springs as a suturce of heat for the college. Energy of this sort is called "geothermal energy". The research has been undertaken in collaboration with Las Alamos National Laboratory (LANL), Sandia National Laboratories, and the Southwest Techrologu Development Institute at Mew Mexica State University.

All of the work discussed here has the purpose of ganning infurmation about the source, oge, quontity, and properties of the woter of the hot springs. This information is necessory for two main purposes. First is to help in the evaluation of its geothermal potential, for which it is necessary to know how much water is available and how hot it is. The second purpose is to have information about the quantity and properties of water coming from the springs before water is removed for other purpases, so that the aracess can te stapped if it has an adverse effect on the hot springs. 


\section{MAPS}

Haps $i-5$ show the riantezums hot springs and surrounding area in Increasing detall. Maps 4 and 5 will be referred to in many other sections. Following are some important points to note about each of the maps:

MAP : The Gallings River (or Gallinos Creek) originates about $30 \mathrm{~km}$ west of Montezuma at an elenstion of about 3300 meters. After passing Montezuma it flows through Las Vegas and continues south to join the Pecos River. The latter continues into Texas, where it meets the Rio Grande, which in turn empties into the Gulf of Mexico. The Gallinas basin covers about 200 square $\mathrm{km}$ west of Montezuma. This is the area which drains into the Gallinas, and includes other smaller streams which join the Gallinas. The river serves as the woter supply for Las Vegas and the surrounding communities. Water is removed from the river above Montezuma and is stored in the Peterson Reservoir, which is shown just south of Montezuma on the map. The scale of this map is $1 \mathrm{in}=2.9$ miles.

MaP 2: Map 2 is produced by the United States beolagical Survey. It is called a topographical map tecause it chows hills and valleys thy the use of contour lines. Two gaging stations are shown on the river. A gaging station measures the height of the surface of the river. This was done at the lower gaging station by fastening a wooden board marked in intervals of 0.1 foot to a bridge support that was in the river. Thus an atserver could read the level of the river on the gage. It is not necessary that the bottom of the gage be at the bottom of the river. By measuring the flow of the river at different gage readings, a table of gage readings against river flow can be estatilished. This is called a rigting table. A graph can be drown from the rating table. For any future gage readings, the corresponding flow of the river could be read from the graph. The lower gaging stotion required periodic visual readings and was used last on Dec. 31, 1966, and removed after that date. The upper station operates automatically: readings of gage measurements are recorded continuously with an instrument.

See Sections $X$ and $Y$ for further information and examples of rating tables and graphs.) 
The gaging stations have been used to estimate the flow of water in the river at frequent intervals, and thus the total amount of water produced by the river on a daily and yearly basis. This information is important in calculating the amount of water available for different purposes, particularly to meet the needs of the city and for irrigation of farms and feeding livestock. In New Mexico, where water is in short supply, different individuals and institutions have traditional and legal rights to specific amounts of water. If more than the allocated amount is removed from the river, those living downstream may be deprived of water that is essential for them. Thus many people depend on reliable information about river flow and the proper use of water rights by those taking water from the river. This is especially important since the removal of water, both legally and illegally, is not monitored by any authority

Map 2 is drawn to a scale of 124000 , meaning that a $1 \mathrm{~cm}$ measurement on the mop corresponds to a distance 24000 times as great, or $24000 \mathrm{~cm}$.

Haf 3: This map was uram by students anu teachers at the united World College for use in orienteering, using map 2 as a basis, but including much more detail.

MAP 4: This map has been prepared by enlarging map 3 twice, by $141 \%$ each time. Sampling locations in the river and hot springs are shown; these $w i l l$ be referred to in other sections. The hot sorings are lacated tetween points F2 and F3, mainly on the south bank of the river, between the river and the road.

MAP 5: Much more detail of the springs ares is provided on this map. Foint 27 on map 5 is slightly upriver from F2 on map 4 ; point 40 is upstream about 50 meters from $F 3$. Table 1 gives information on egch of the points shown on map 5. 


\section{Questions}

1. Convert the scale of map $1 \mathrm{ta} \mathrm{cm}$ and $\mathrm{km}$. What is the scale in terms of $1: x$ ?

2. On map 2, what distance (in meters) corresponds to $1 \mathrm{~cm}$ ?

3. By what ratio is the scale of map 2 larger than that of map 1 ?

4. Gri map 3, what distance (in meters) corresponds to $1 \mathrm{~cm}$ ?

5. On map 3, what measurement corresponds to $1 \mathrm{~km}$

6. Map 4 is the same as map 3 , except expanded twice ty $141 \%$ each time. What scale should be shown for map 4 ? What distance corresponds to 1 cm? What measurement corresponds to $100 \mathrm{~m}$ ?

7. Express the scale of mag 5 as $1: x$ and as $1 \mathrm{~cm}=4 \mathrm{~m}$.

6. How much larger is the scale of map 5 than that of map i?

9. Determine the distance (in feet and meters) along the river from point 27 to point 40 on

map 5 .

10. Determine the distance (in meters) from $F 3$ to $F 4$ on map 4.

11. On map 5 , approximately how many different springs on land have been identified (see also Table 1)? What problems make this counting difficult?

12. Foints 28 to 40 may correspond to individual springs in the river. What are the arguments for and against this position? How could you test the hypathesis that 13 springs do arise in the river? 


\section{Las Vegas and Montezuma, NM}

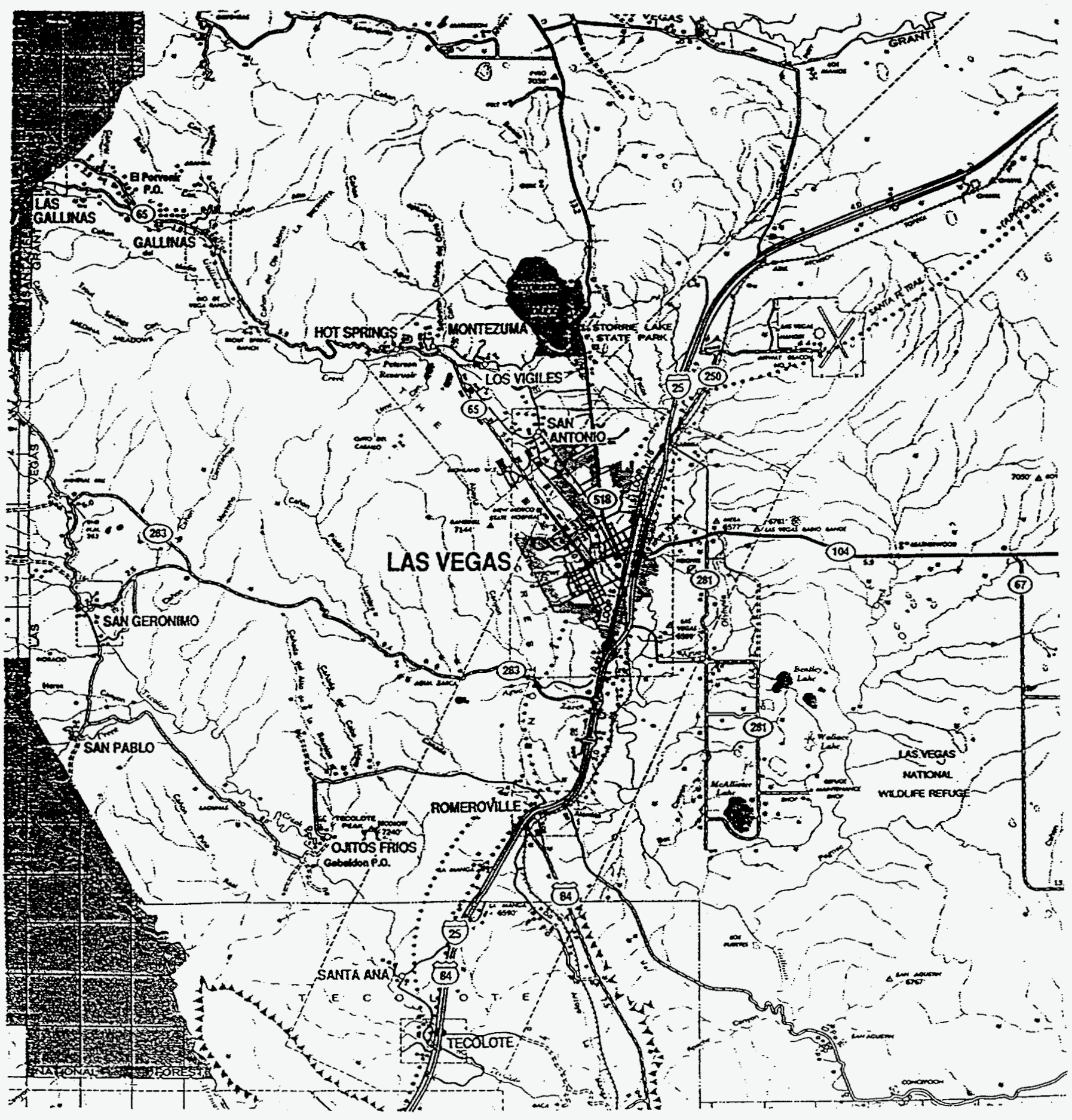

Scale : 1 in $=2.9$ miles

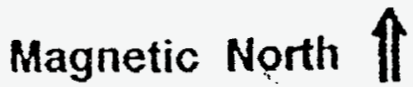




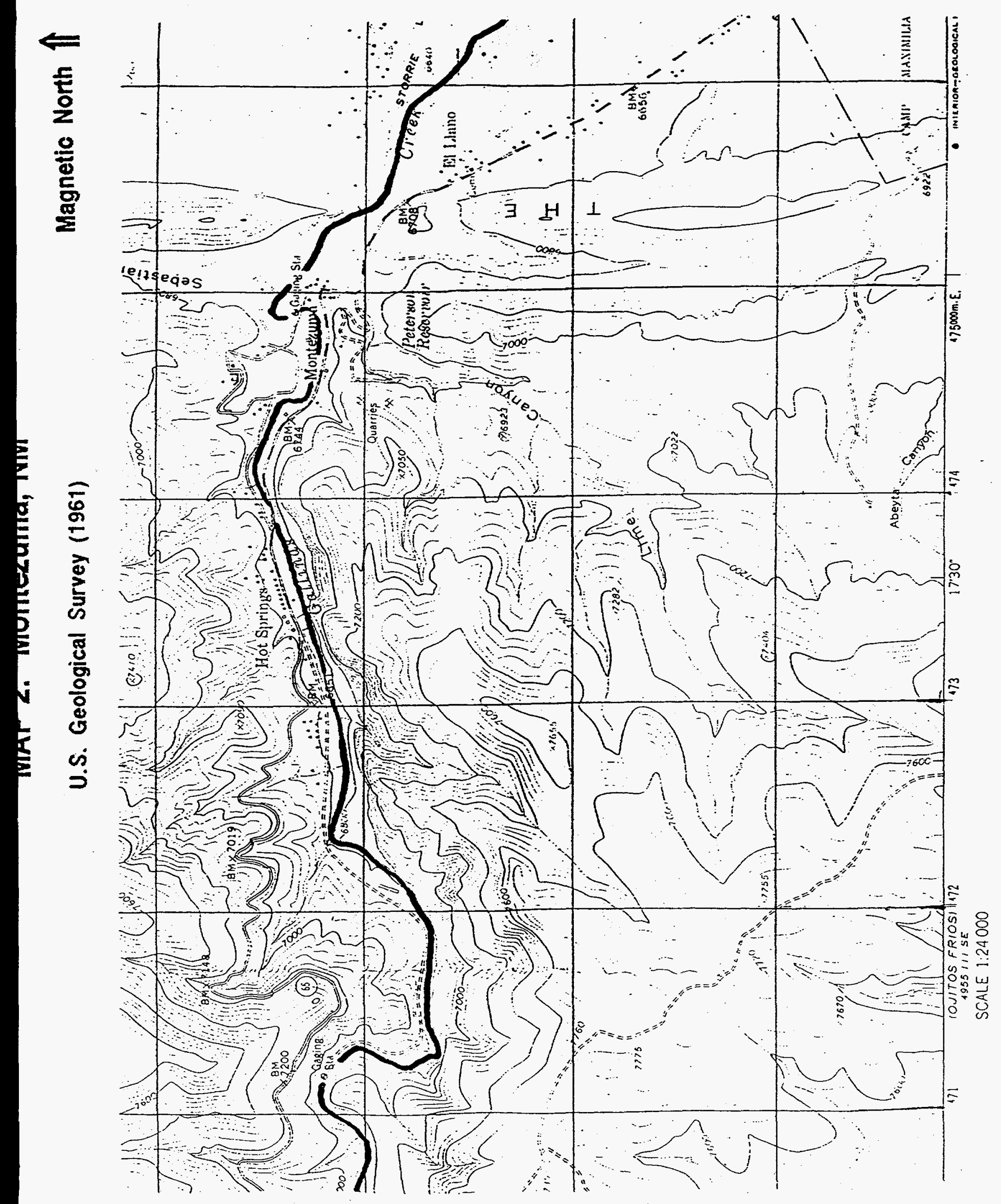




\section{MAP 3: Montezuma, NM}
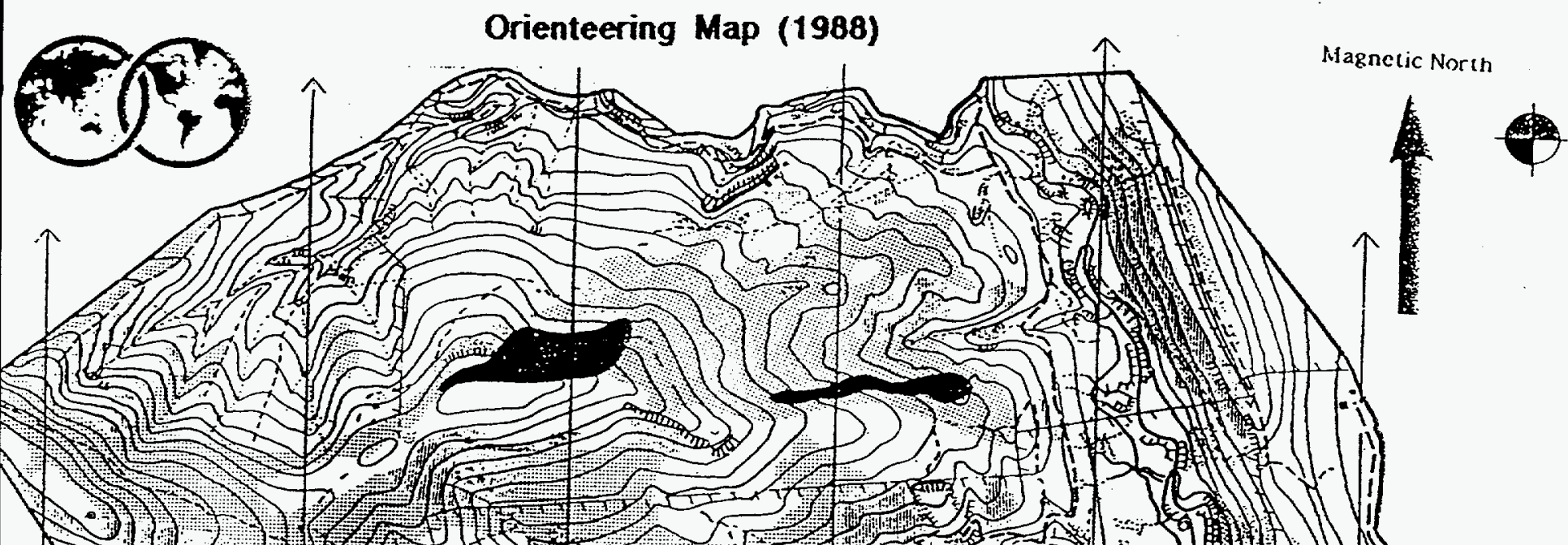

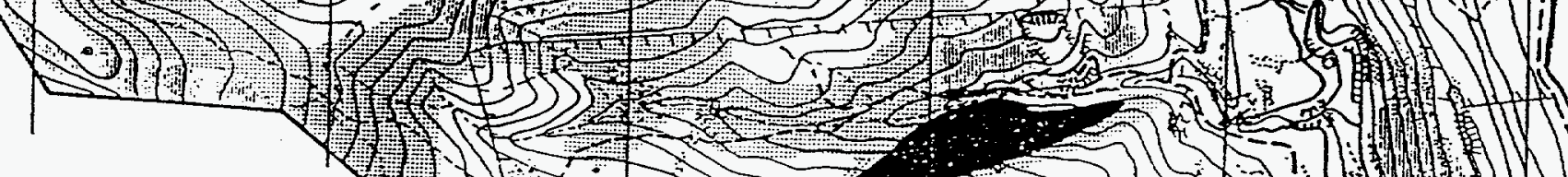

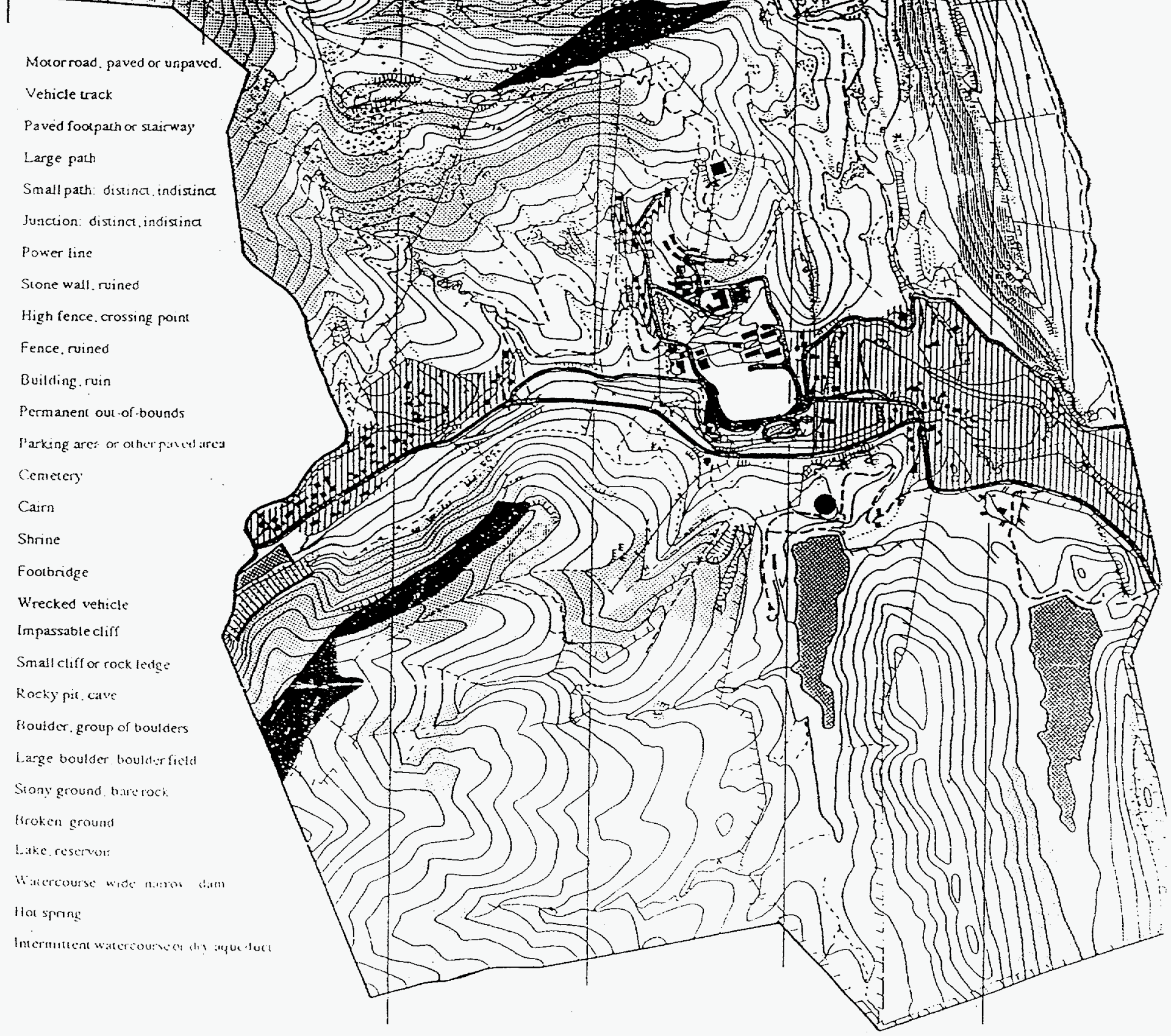

Scale 1:15000 


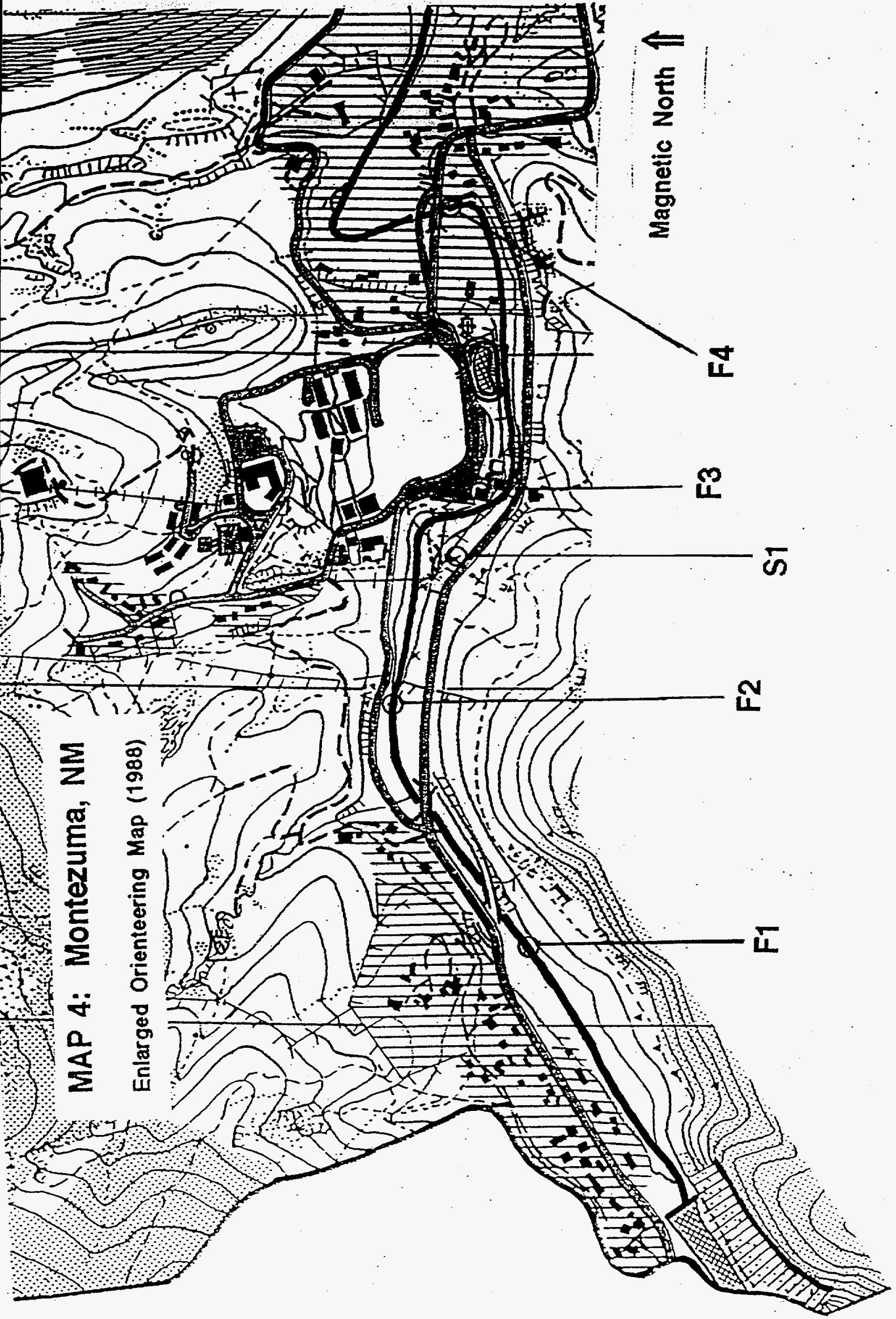




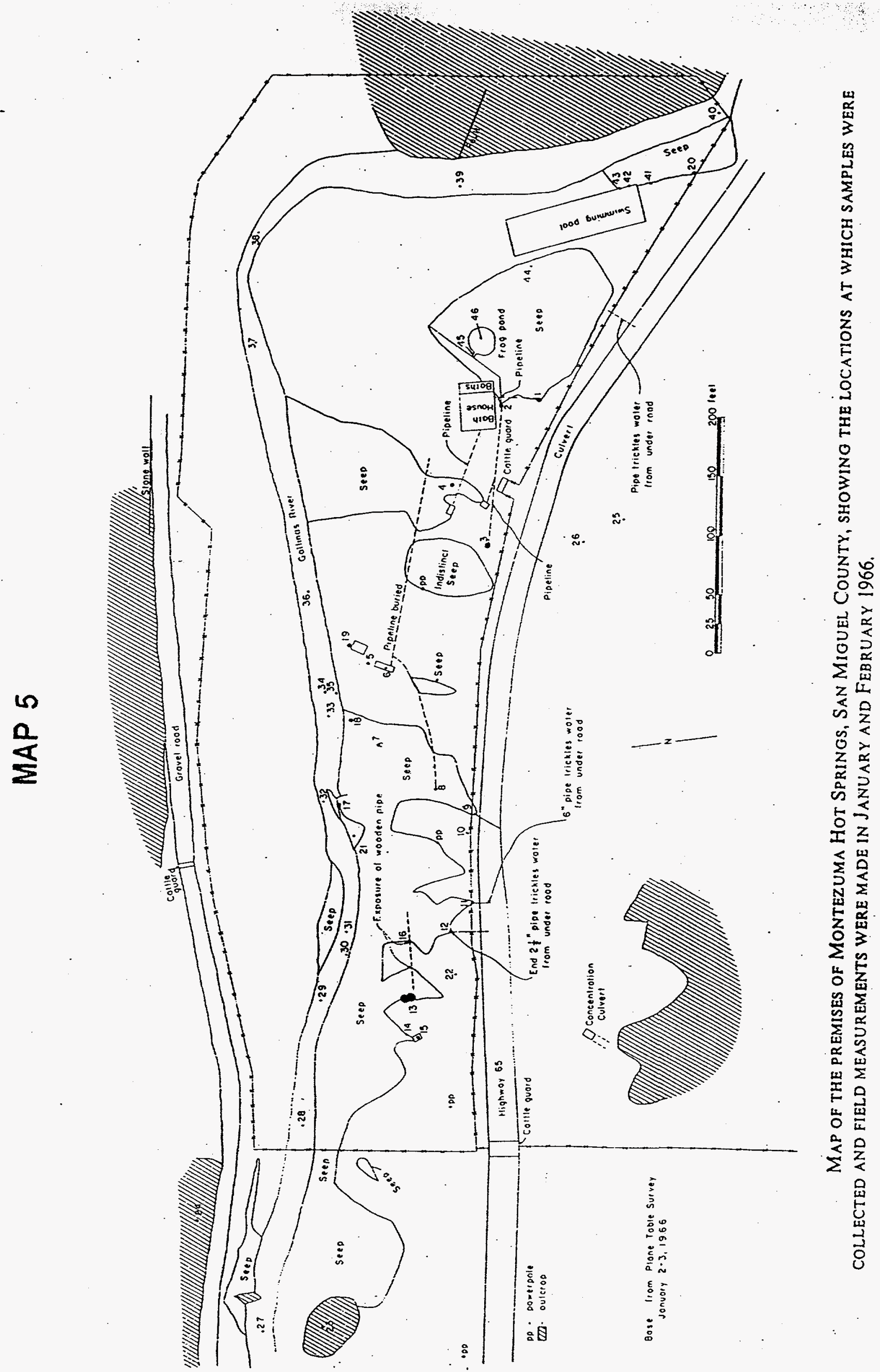




\section{TABLE 1}

Field data for Montezura tot Springs, February 4, 1966

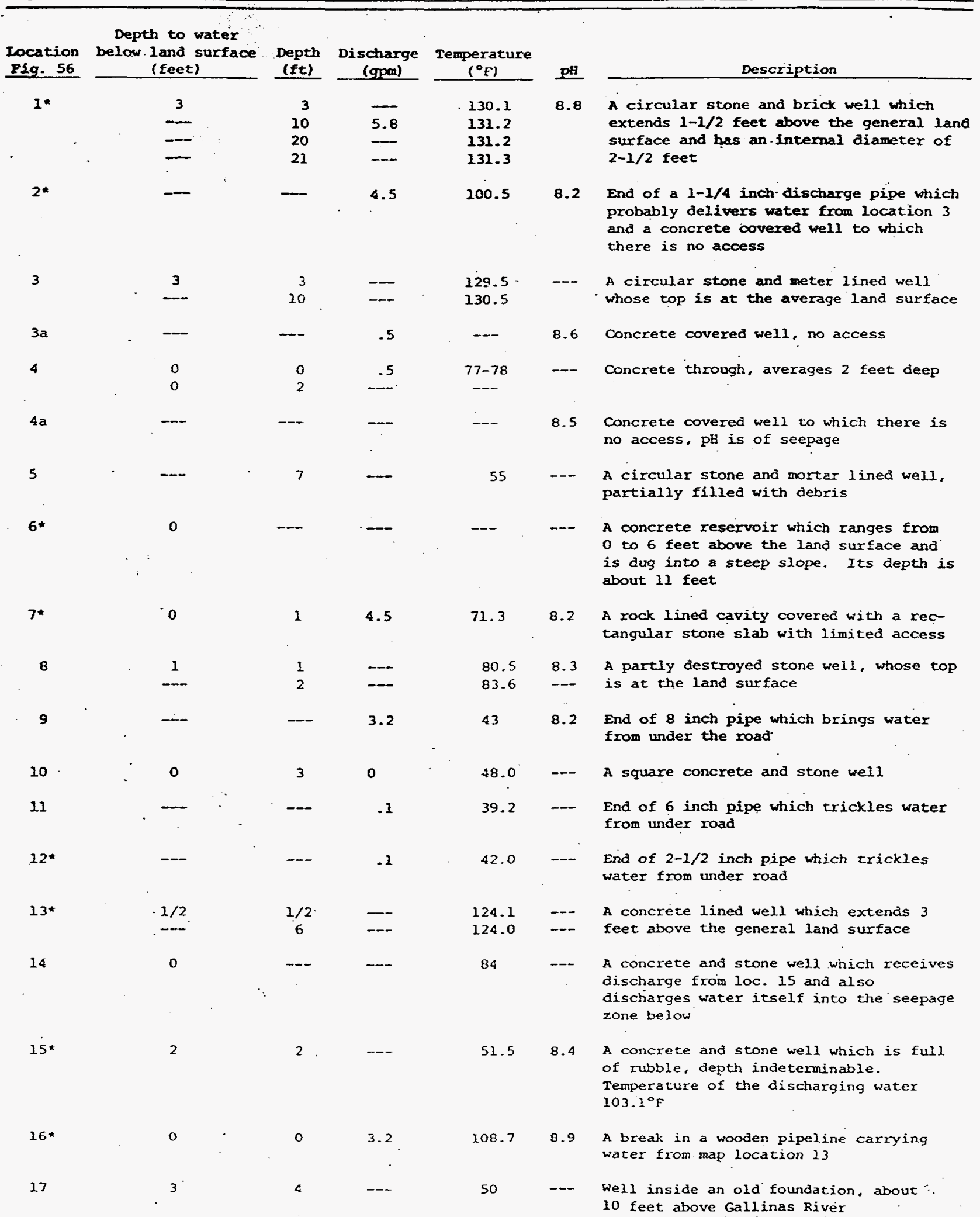


Field data for Montezuma tot Springs, February 4, 1966 (cont.) : i

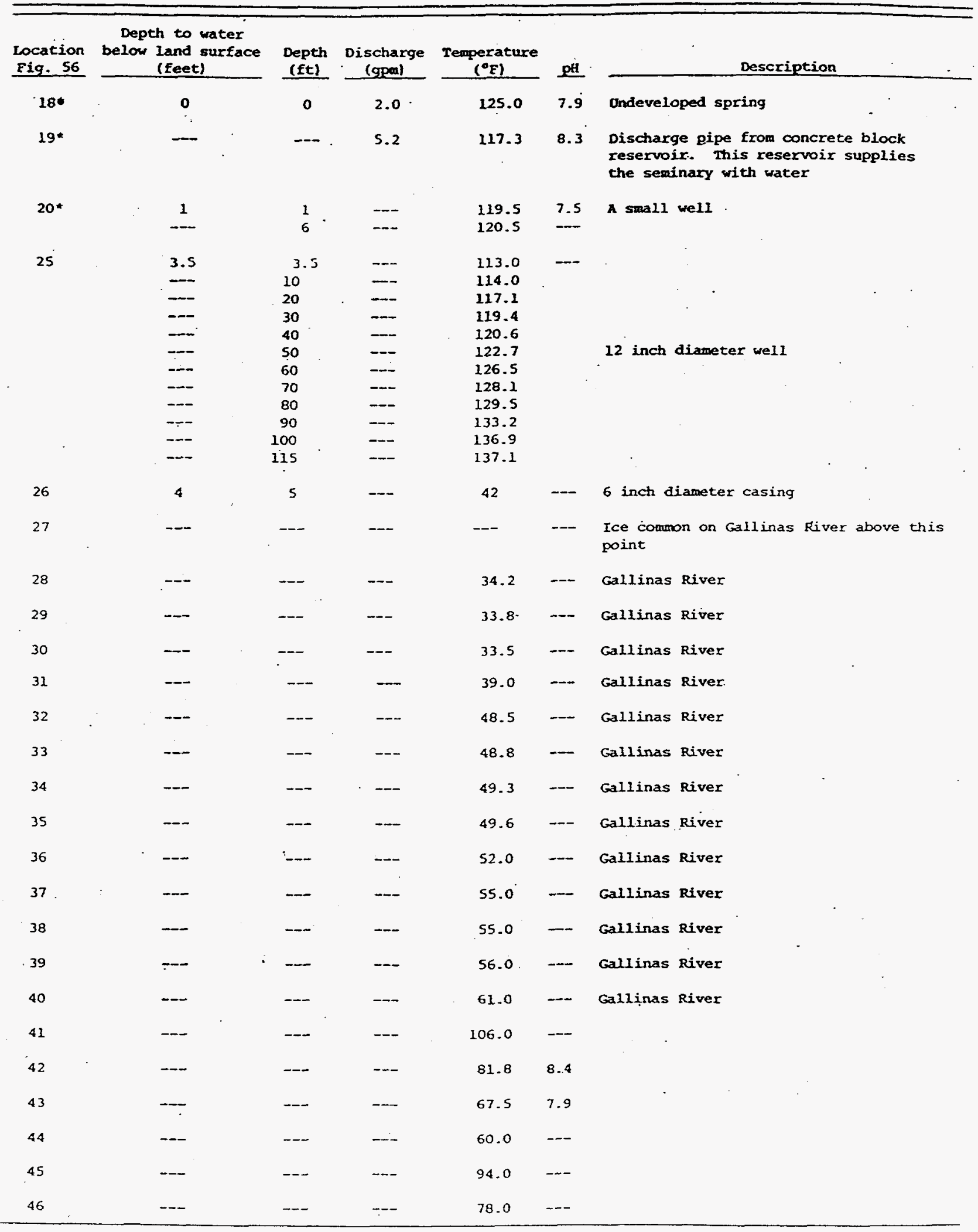




\section{IOTAL OUTPUI OF THE HOI SPAINGS}

\section{(Estimâtes priữ tó ig94)}

Two previous estimates have been recorded for the total out flow of the hot springs. The first was made in 1966 and reported in the Catalog of Thermal Waters in New Mexica.

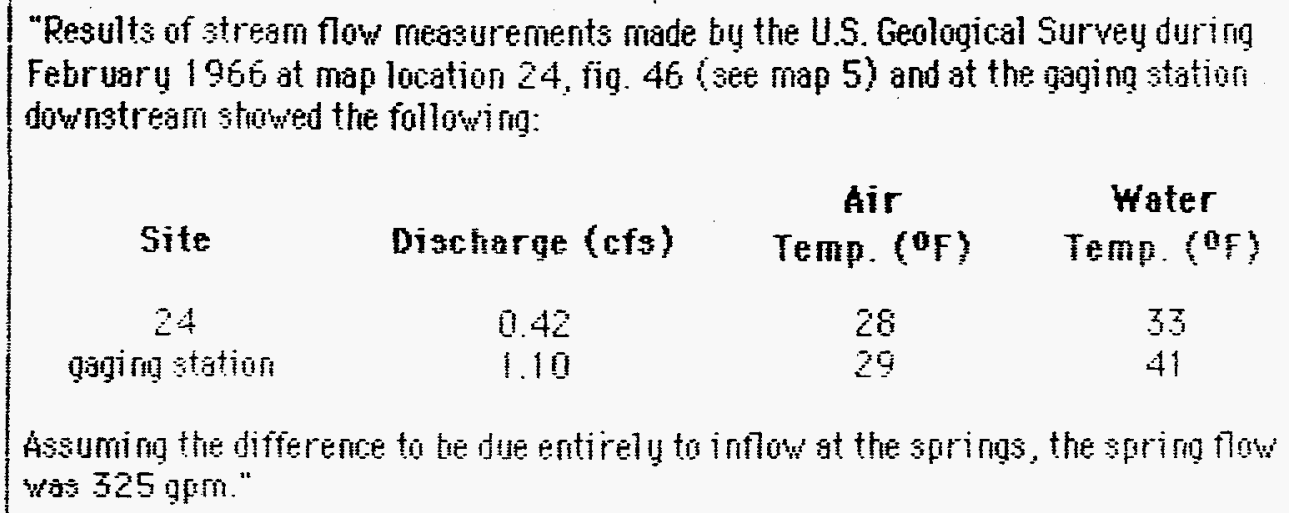

$$
\text { Site }
$$$$
24
$$

Qigirustation

$$
\text { Discharge (cfs) }
$$

$$
0.42
$$

1.10

29

Assuming the difference to be due entirely to infow at the springs, the spring fow was 325 pुm."

The toto const of strom ilow values dischame in cubic feet per second above and below the springs. The difference was assumed to be the contritution from the hot springs. one value was determined by actually measuring the flow of the stream at site 24 (map 5), just above the hot springs. (See also F2 un map 4.) The other value was obtained by measuring the depth of the river at the gaging station atout 500 meters downstream from site 40 un map 5 . (Sée alsu f4 un mop 2.) By comporing the reading on the gage to known values of stream flow and gage readings, the flow could be determined.

\section{See Section on Rating Tables for further information and examples.}




\section{Attachment $E$, page 13}

In iḡ $\bar{s}$ a different method was used to estimate the total now or the springs. The relevant section trom the report

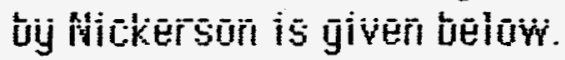

"The estimation of the total output of the springs is extremely difficult due to the nature of the seepage, and the fact that the primary springs have been routed and retouted numerous tines. The main spring near the tisthiouse, dizcharges approximstely $15 \mathrm{gpm}$ into the bothhouse as measured of the bathhouse. ...The St. Michsel Spring disctarges approximately $5 \mathrm{gpm}$... The two middle springs discharge approximately $4 \mathrm{gpm}$, and $1.5 \mathrm{gpm}$,... This gives about $26 \mathrm{gpm}$ from the largest springs, plus an estimate of approximatelus 5 apm more from uncontained seeps, for a total discharge of approximately 31 gpm."

Nickerson did not identify the springs tested according to hiap i. but the first two are certainly springs 1 and 13 , respectively. One of the "middle springs" is likely number 19; the other is uncertain, and may not be on the map because of changes mentioned by Nickerson.

\section{Questions}

1. Use the U.S.G.S data to calculate the discharge in gallons per minute (gom) and in $\mathrm{m}^{3} \mathrm{~min}^{-1}$. Comment on the results.

2. The two methods give very different results for tots! discharge from the hat springs. Comment on passible suurces of arrar for each methad. At this stage do you feel corifident in chasing one result as more reliatie than the other? oiscuss your reasoning.

Further information about the discrepancy bet ween these two estimates of flow may be obtained from additional data gathered at different times and locations. These measurements are descrited in Section $x$ 


\section{MEASUREMFNIS QF SEUFARL QUPNIITIES TO EUALUAIE TOIAL FLUU}

The followinn measurements were taken at different locations, and may be useful in evaluating the flow medsurements in Section $X X$.

conductivity, $\mathbf{A}_{25}$ : an indication of the total concentrations of all ions; higher values mean a higher concentration of ions. Measurements were taken with a portable instrument in the field and with a different instrument in the lab. The latter should be regarded as more rehable, especially at higher temperatures.

$\mathrm{pH}$ : a measure of the acidity of the water; a higher value indicotes a less acidic solution. Measurements were made with a portable instrument in the field, and with a more reliable instrument in the laborstory.

temperature: measured in the field with an electronic instrument

chloride ion concentration, $\left[\mathrm{Cl}^{-}\right]$: measured in the latoratory by titration with silver ion, and expressed as parts permillion (pom)

The above measurements were made at locatians $F 2, F 3$. and $F 4$ (see $M a p ~ 4)$ and at the bathouse spring (51), site 2 on Map 5 . Measurements made at approximately the same time at more than one river location are collected in Table 2. 


\section{TABLE 2}

\section{Measurements in River above and below Hot Springs}

\begin{tabular}{|c|c|c|c|c|c|}
\hline \multicolumn{2}{|r|}{ Sampling location $\Rightarrow$} & \multirow[t]{2}{*}{ F2 } & \multirow[t]{2}{*}{ F3 } & \multirow[t]{2}{*}{ F4 } & \multirow[t]{2}{*}{51} \\
\hline Date & Messurement $\|$ & & & & \\
\hline \multirow[t]{4}{*}{$7 / 12 / 94$} & $\mathrm{~A}_{25} / \mu$ mhos $\mathrm{cm}^{-1}$ (field) & 315 & 680 & 590 & 1200 \\
\hline & $p H$ (field) & 9.31 & 9.47 & & 9.59 \\
\hline & Temperature $/ 0 \mathrm{C}$ & & 28.9 & & 54.4 \\
\hline & {$\left[\mathrm{Cl}^{-}\right] / p \mathrm{pm}$} & 7 & 64 & & 141 \\
\hline \multirow[t]{5}{*}{$7 / 13 / 94$} & $\mathrm{~A}_{25} /$ umhos $\mathrm{cm}^{-1}$ (lab) & 307 & 420 & 437 & 860 \\
\hline & $p H($ field $)$ & 9.26 & 9.42 & 9.41 & 9.65 \\
\hline & $p \mathrm{H}$ (laboratory) & 8.52 & 8.63 & 0.62 & 8.95 \\
\hline & Fomperaturelot & 22.2 & 254 & 235 & 540 \\
\hline & {$\left[\mathrm{cl}^{-1} /\right.$ opm } & 49 & 35.8 & 32.5 & 150 \\
\hline \multirow[t]{2}{*}{ 7/29/95 } & $A_{25} /$ umhos $\mathrm{cm}^{-1}$ (field) & & 410 & 422 & \\
\hline & Temperature/oc & & 297 & 26.9 & \\
\hline \multirow[t]{3}{*}{$7 / 31 / 95$} & Azs umhas $\mathrm{cm}^{-1}$ (field) & 235 & 370 & 400 & \\
\hline & oH (field) & 899 & 9.18 & 9.23 & \\
\hline & Temperature/0 $\mathrm{C}$ & 24.5 & 292 & 27.0 & \\
\hline
\end{tabular}

Notice that river messurements were taken at $F 2$. immediately above the springs, and at $F 3$, immediately below the sriring nifferences between messurements at these two locitions should be due to the water entering the stream from the hot springs. Measurements on the water from the bathouse spring are given for comparison. Measurements are also given for $F 4$, further below the springs, at appraximately the site of the U.5.5 lower goging station. Examine the data carefully. recolling the large discrepancies in tatal spring flow estimates. 


\section{Questions}

1. Which of the above measurements are most iikely to differ from one day to another? Why?

2. Can you account for all changes between F2 and F3? Explain your reasoning.

3. Would you expect measurements taken at $F 3$ and $F 4$ to differ from each other? Explain.

4. Which megsurement(s) shaw clear and consistent diferences between $F 3$ and $F 4$ ?

5. How could the these) difference(c) be accounted for? (Note that the measurements are usually taken a tew minutes apart from esch other, so conditions are not likely to change during such a shot interval of time)

6. Why do other measurements not show a clear and consistent diference bet ween the two locotions?

7. Suggest wys of testing your hypothesis(es) in your answer to

question 5 . 

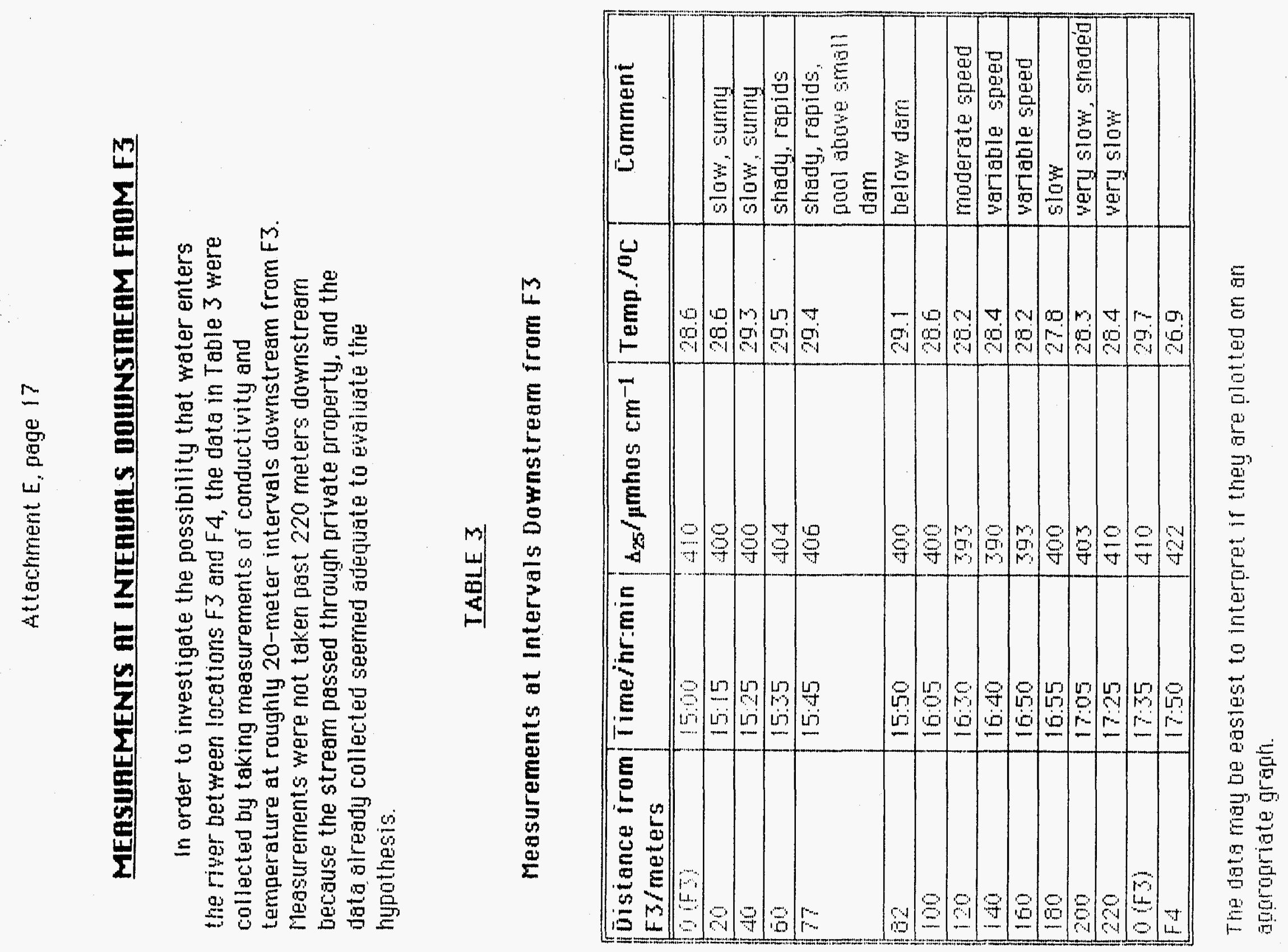


\section{Questions}

1. To what extent are the data above consistent with other data already piresented?

2. Do the measurements change steadily with distance away from F3? If not, where do discrepancies accur?

3. How could any discrepancies be accounted for?

4. If water enters the river between $F 3$ and $F 4$, does the evidence indicate it to be "fresh" water like that in the stream above the sorings), or hot springs mater?

5 where do the data suggest that witer enters the river? is there more than one inlet?

6. Whch s a better indication of water entering the stream, conductulty or tempenature? Explain your reasoning.

7 Acroun for the change in temperature at $F 3$ over iwa and ghe-half hours, even though the conductivity did not change. 
ATTACHMENT F

The Hot Springs

at

Montezuma, New Mexico

Science Education Materials for Teachers

Section 6 


\section{MAPS}

riag $i$ is from The Roads of New Mexica, Shearer Fublishing, 1990. This was compiled from county maps issued by the New liexico siate Highway and Transportation Department.

Map 2 is one of a set of U. S. Geological Survey maps which are produced for all areas of the United States. These are availatle from selected U.S.G.S. of fices and from many shops specializing in equipment for hiking and camping.

The Gailinas is a very smail river, only about 5 - 10 meters in widh in the vicinity of the hot springs, and less than $0.5 \mathrm{~m}$ in depth in most places during low flow.

Many different quging methods are used for determining river flow. A visit to a local gaging station would be of interest to students.

Water rights will be discussed in more detail in Section $z$.

Map 5 anu Toule are taken from $w$ K Summers, A Catolug of Themal Waters in New Mexico Hydrologic Report 4, New Mexico Burea of Mines and Mineral Resources, Socorro, MM, 1976.

\section{Questions}

Aims: interpret different scales on mags

convert units from one system to another interpret and estimate distances on maps

interpret data and develop hypotheses for their explanation propose tests of hypotheses

\section{Answers}

1. $\frac{1 \mathrm{~cm}}{2.9 \mathrm{mile}} \times \frac{2.54 \mathrm{~cm}}{1 \mathrm{in}} \times \frac{1 \mathrm{mile}}{1.6 \mathrm{~km}}=\frac{0.55 \mathrm{~cm}}{1 \mathrm{~km}}=\frac{1 \mathrm{~cm}}{1.8 \mathrm{~mm}}$ n: $1 \mathrm{~cm}=1.8 \mathrm{~mm}$ 


$$
\frac{i \mathrm{~cm}}{1.8 \mathrm{~km}} \times \frac{i \mathrm{~m}}{100 \mathrm{~cm}} \times \frac{i \mathrm{im}}{1000 \mathrm{~m}}=\frac{i}{1.8 \times 10^{6}}
$$

Ans: $1: 180000 \overline{0}$

Note: Proper use of significant figures has been used in the atove calculations. The number 1 should be regarded as exact, but its equivalents in miles and $\mathrm{km}$ are reliable to only two significant figures. The final expression of $1: 180000$ is conventional rather than accurate and should not be regarded as containing more than twa significant figures. All subsequent calculatians in this section cont ain only twa significant figures, and the answers may be expressed in scientific notation to avoid ambiguity.

$$
\text { 2. } 24000 \mathrm{~cm} \times \frac{1 \mathrm{~m}}{100 \mathrm{~m}}=240 \mathrm{~m}
$$

Bns: $2.4 \times 10^{2} \mathrm{~m}$

$$
\text { 3. } \frac{160000}{24000}=7.5
$$

\section{An: 7.5 times gare}

Wute: The smaler the second number in the scole ratio, the brger the scale of the map the smaller the distance corresponding to the same unit of measurement).

4. Sirre $1 \mathrm{~cm} \Rightarrow 15000 \mathrm{~cm}, 15000 \mathrm{~cm} \times \frac{1 \mathrm{~m}}{100 \mathrm{~cm}}=150 \mathrm{~m}$

\section{Alv: $1.5 \times 10^{2}$ 並}

5. $1 \mathrm{~km} \times \frac{1 \mathrm{~cm}}{150 \mathrm{~m}} \times \frac{1000 \mathrm{rm}}{1 \mathrm{~km}}=6.7 \mathrm{~cm}$

\section{Ans: $6.7 \mathrm{~cm}$}

6. $1.41 \times 1.41=1.99$ This is an expansion by a factor of 20

$$
1: 15000 \Rightarrow 75 \mathrm{~m}
$$

$$
100 \mathrm{~m} \times \frac{1 \mathrm{~cm}}{75 \mathrm{~m}}-1.3 \mathrm{~cm}
$$

ins: $1.3 \mathrm{~cm}$ 
7. The scale shows $113 / 16$ in $\Rightarrow 200 \mathrm{ft} ; 1.8 \mathrm{in} \Rightarrow 24000$ in

$$
\begin{aligned}
& \frac{2400 \mathrm{in}}{1.8 \mathrm{in}}=1.3 \times 10^{y} \\
& \text { Ans: Acaie }=\mathrm{i}: \mathrm{i} \text { 1300 }
\end{aligned}
$$

$\underline{\mathrm{OR}} 4.6 \mathrm{~cm} \Rightarrow 200 \mathrm{ft} ; 200 \mathrm{ft} \times \frac{30.5 \mathrm{~cm}}{1 \mathrm{ft}}=6100 \mathrm{~cm} ; \frac{6100 \mathrm{~cm}}{4.6 \mathrm{~cm}}=1.3 \times 10^{9}$ Ans: Scale $=1: 1300$

6. $\frac{180000}{1300}=14 \times 10^{2}$

\section{An: $1.4 \times 10^{2}$ inies as arge}

9. The simpiest method is to take a piece of string or wire, hold the end at one point, make it follow the bends of the river on the map, mark the other point, and measure the length of the string corresponding to the distance between the two points on the map. This gives a value of 12 in or $305 \mathrm{~cm}$.

12. ir $\times 1300$ (scale factor) $\times \frac{1 \mathrm{ft}}{12 \mathrm{in}}=1300 \mathrm{ft}$

$$
30.5 \mathrm{~cm} \times 1300 \times \frac{1 \mathrm{~m}}{100 \mathrm{~cm}}=400 \mathrm{~m}
$$

Ale: $1.3 \times 10^{3}$ ftor $40 \times 10^{2} \mathrm{~m}$

10. The distance is $61 \mathrm{~cm}$; the scale is $1 \mathrm{~cm}=75 \mathrm{~m}$

$$
\begin{aligned}
& 6.5 \mathrm{~cm} \times \frac{75 \mathrm{~m}}{1 \mathrm{~cm}}=490 \mathrm{~m} \\
& \text { Ane: } 49 \times 10^{2} \mathrm{~m}
\end{aligned}
$$

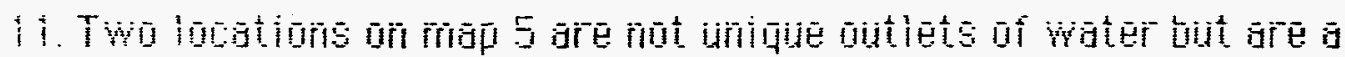
broken pipe (16) and an outlet from a spring already noted (19). Point 27 is a reference point rather than a spring. Other points, such as 41-46 are in two areas where water seeps from the ground, without a specific source. These could correspond to two diffeent sources, or a larger number. Dther areas of seeps do not hove any numbers assigned to them. If locations within seeps are counted as one source, and if unumbered seeps are 
inciuded, the number of springs on the iand number appraximateiy $\overline{3} 2$. The actual number'may be greater than this, if there is more than one spring

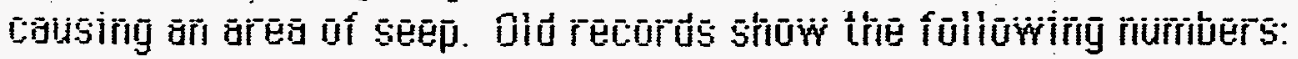

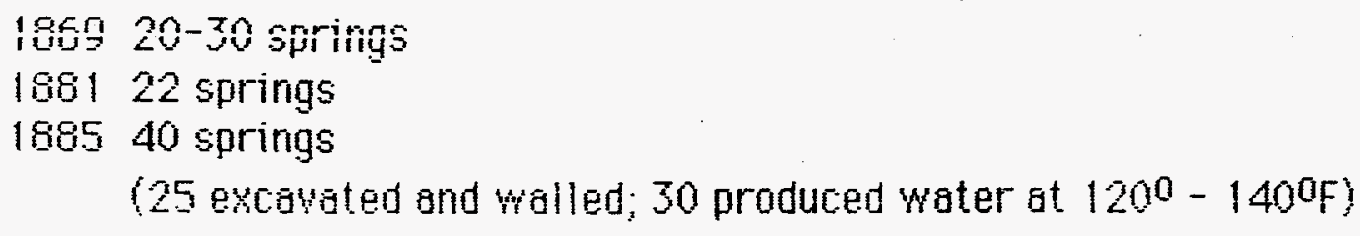

12. For: The temperature at the points indicated is far higher than one would expect in February from a general flow of hot spring water into the river. (See river temperatures, section $M$.) These high temperatures indicate point sources

Against: Points close together may correspond to one spring producing a large amount of hot water. No indication is given of temperatures at ather locations. No evidence is available to rule out one or more small springs between points 36 and 37 , for example.

Test: To find the actus number of springs, g detalied grid system conld ba set up for the river, and temperature measurements could be taken at many regularly spaced locations over a short period of time. The would give a much more detaled pattern of temperatures, from which sources of hat water could be inferred. 


\section{IOIIIL OUTPUT OF THE HOT SPAINGS}

\section{Questions}

Aims: convert units from one system to another recognize that published information may contain error analyze sources of error in procedures

evaluate results obtained by different methods

In this and the following sections, students (and teachers) will have to ded with ambiguous data. In some cases data can be interpreted with confidence; in others no definite conclusion is possibie. An important skili is the ability to distinguish the degree of certainty with which conclusions can be extracted from a set of data. In real situations, a first set of data often leaves more than one possible solution. The scientist's task then is to design further tests to reduce the number of possible conclusions.

\section{Answers}

1. The difference in flow is $1.10-0 / 42=0.60 \mathrm{ft}^{3} \mathrm{~s}^{-1}$.

$$
\frac{0.68 \mathrm{ft}^{3}}{3} \times \frac{7.48 \mathrm{gil}}{\mathrm{ft}^{3}} \times \frac{60 \mathrm{~s}}{\mathrm{~min}}=3.1 \times 10^{2} \mathrm{gal} \mathrm{mint}^{-1}
$$

\section{An: $31 \times 10^{2} \mathrm{manin}^{-1}$}

The value given in the article is not consistent with the data provided. Either there is a misprint in the original data, or the calculation is wrong. We tend to think that published scientific infurmation is authoritative, but such errors are not uncommon.

$$
\begin{aligned}
& \frac{0.68 \mathrm{ft}^{3}}{s} \times\left(\frac{0.305 \mathrm{~m}}{\mathrm{ft}}\right)^{3} \times \frac{60 \mathrm{~s}}{1 \mathrm{~min}}=1.16 \mathrm{~m}^{3} \mathrm{mun}^{3} \\
& \text { or } \\
& \frac{0.68 \mathrm{t}^{3}}{s} \times\left(\frac{12 \mathrm{~min}}{1 \mathrm{ft}}\right)^{3} \times\left(\frac{2.54 \mathrm{~cm}}{1 \mathrm{~m}}\right)^{3} \times\left(\frac{1 \mathrm{~m}}{100 \mathrm{~cm}}\right)^{3} \times \frac{60 s}{1 \mathrm{~min}}=1.16 \mathrm{~m}^{3} \mathrm{minh}^{-1}
\end{aligned}
$$




\section{Problems with flow differences}

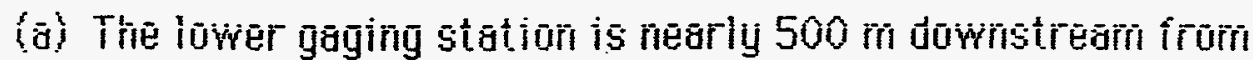
the end of the springs. Other sources of water might exist between F3 and the gaging station, , which would incresse the differences between the quantities measured at the two locations. Students might not come up with this suggestion at this point; it could be left open until the next section.

(b) It is difficult ta take megsurements within oniy a short time intervai. If the flow of the river changes signiricantiy during the course of an hour, measurements taken over that interval are not comparable. These changes do in fact occur at some times (see Section YY), but students probably are not aware of that fact at this time, so are inikely to corne up with this suggestion.

\section{Problems with estimates of flows of individual springs}

(a) Dutflows from seeps are difficult or impossible ta mescure.

(b) Not all sources were measured (compare description of megsurements with Table 1), al though the totals are similar.

(c) Some springs may be in the river.

Students should te atile to come up with at least two of these possibilities.

The discrepancy between the two estimates is very large, but there is nothing so far to indicate that one is clearly more reliable than the other 


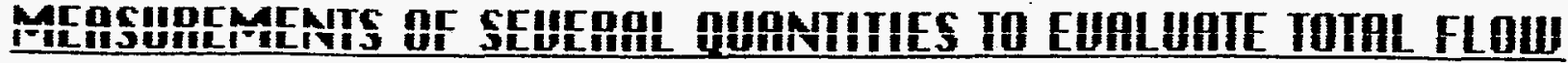

\section{Questions}

Aims make reasoned predictions of possible experimental results account for experimental results in terms of simple models evaluate experimental data to find patterns interpret data and develop hypotheses for their explanation propose tests of hypotheses

\section{Answers:}

1. Temperature varies acording to the weather. Change with season should be much greater than variation from ane day to the next. lon concentrations depend on the amount of water, since heavy rainfall dilutes the water in the river. pH may also change for the same reason, but not to such a great extent bvecase the river water is buffered to a significant extent.

Only relatively advanced students win find this last argument meaningful. The main point to this question is to encourage students to consider and evaluate their ideas, rgther than to come up with a specific set of answers. Claser examination of the data chould be used to evaluate the predictions

2. From $F 2$ to F3,

$\Lambda_{0}$ increases because of inflow of springs with higher ion concentrations

pH thcreases slightly because of inflow of springs with higher $\mathrm{aH}$

temperature increases because of inflow of springs with higher temperstures

$\left[\mathrm{Cl}^{-}\right]$incresses considerably because of inflow of sarings with much higher chloride ion concentrgtions

3. No change between $F 3$ and $F 4$ would be expected unlese another source of water enters the stream between these two points. 
4. only temperature shows a substantial and consistent change

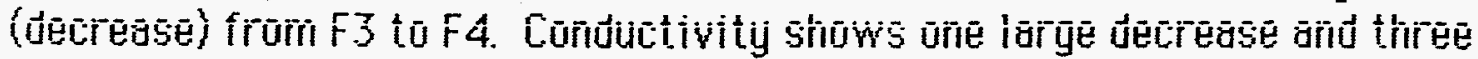
small increases. $\mathrm{pH}$ shows very small changes which ore not consistent in direction. Chloride ion concentration was measured only once at both locations, and shows a decrease.

5. The most likely explanation for a decrease in temperature is the possibility that cooler water enters the river between $\bar{F}$ and $F 4$. Since the measurements were made in July, it is unlikely that contact with the air would cause significant cooling. (This point would be more convincing if air temperature data were available.) If water with relatively low ion concentations enters the river between $\mathrm{F} 3$ and $F 4$, that possibility could account for the decrease in chloride ion concentration (measured on $7 / 13 / 94$ only) and conductivity (measured on $7 / 12 / 94$ ).

6. pH shows changes which are small and inconetent because the ph of the springs is not very different from that of the river. The increases shown in ronductivity measurements are small and inconsistent with the relatively large decrease shown on $7 / 12 / 94$. There is no obvious explanation for the noreases, which are inconsistent with expectations.

7. (a) Take temperature measuremente in the river at regular iletance intervals between $F 3$ and $F 4$;

(b) Conductivity measurements could also be taken, but may not prove as useru as temperature measurements;

(c) Inspect for fresh water inflow along the river between F3 and FA 


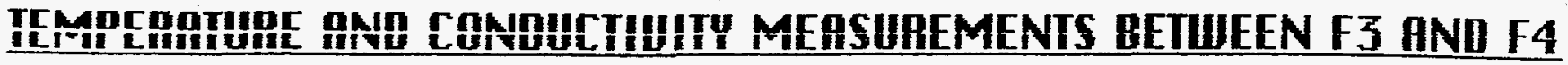

Data for temperature and conductivity should be plotted as a function of distance. If both variables are plotted on one graph (see Graph T1 as an example), any common pattern is more likely to be seen. This graph was plotted using the Cricket Graph program. In order to piot both variables on a common vertical axis, the temperature was multiplied ty a factor of 15 .

\section{Questions}

Aims evaluate the consistency of different sets of data find patterns in data acoount for experimental results in terms of simple models interpret data and develop hypotheses far their explanotion

\section{Answers}

1. Both temperature and conductivity show very similar values at $F 3$ distance $=0$ and 220 meters downetream. At F4, conductivity is slightly higher and temperature slightly lower than at F3. These data were obtained an $7 / 29 / 95$, and appear in Table 2.

2. Neither measurement changes consistently with distance, nor are discontinuties consistent with each other. For example, between 120 and $140 \mathrm{~m}$, tempersture rises and conductivity falls. The opposite happens from 140 to $160 \mathrm{~m}$. Beyond $180 \mathrm{~m}$, both rise. No model can account for this inconsictent pattem of changes. Consistent discontinuities occur at about $60 \mathrm{~m}$ and tet ween 100 and $1230 \mathrm{~m}$ when both values decrease

3 The above changes (about 80 and $100-120 \mathrm{~m}$ ) are consistent with additiona water entering the stream.

4 If additional water enters the stream, it mist be fresh with lower temperature and ion concentration, to account for the decreases in temperature and conductivity.

5. Data are consistent with two inflows at about $80 \mathrm{~m}$ and between 100 and $120 \mathrm{~m}$. Other temperature decreases are contradicted by conductivitu increases except between 80 and $100 \mathrm{~m}$ Inspection of the stream reveals inlets of fresh water at 92 and $106 \mathrm{~m}$. The following measurements were made on the incoming water: 


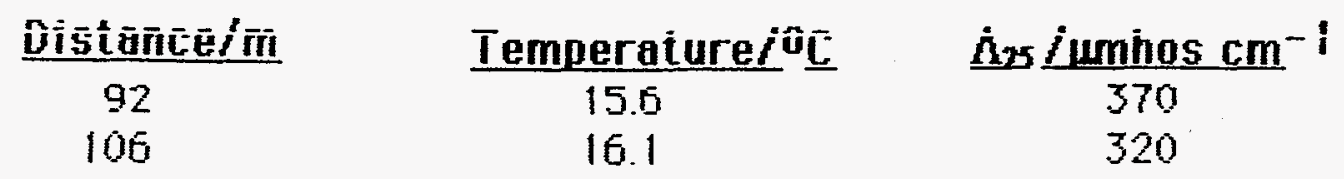

These volues suggest why temperature changes between 60 and $100 \mathrm{~m}$ while conductivity does not. The incoming water has a conductivity only slightly less than that of the stream, while the temperature shows a much greater difference. The misleading decrease at atout 80 m must be due to the abstruction in the river at that point.

6. Neither measurement by itself seens adeudate, since tuth shuw decregses where the other measure increases.

7. The temperature at $F 3$ rose by $1.1^{\circ} \mathrm{C}$ in the late af termoon. This could be due to warming by the sun, which should not affect conductivity.

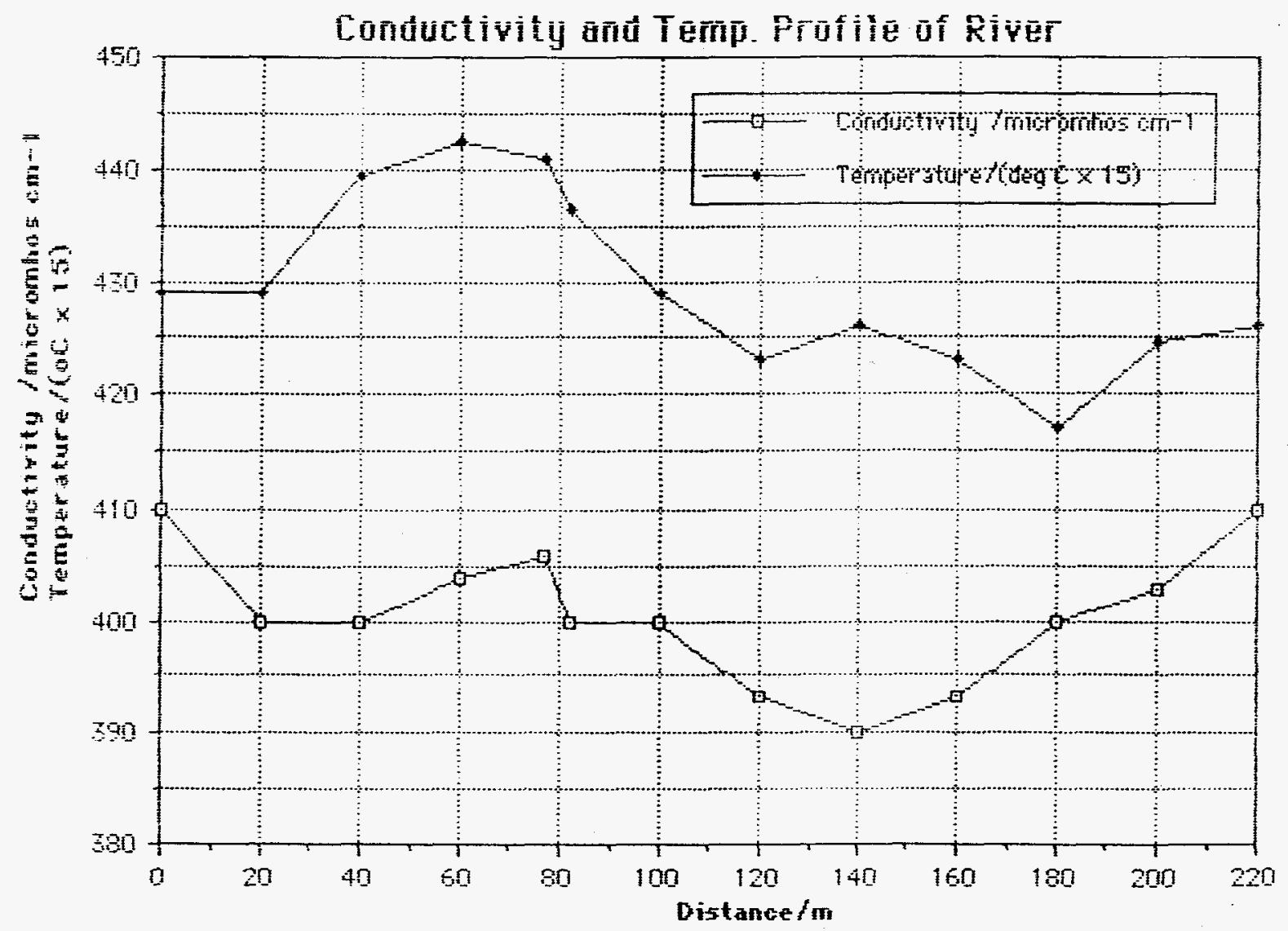

